\title{
CAROLINA BAYS
}

\section{OF THE SAVANNAH RIVER PLANT}

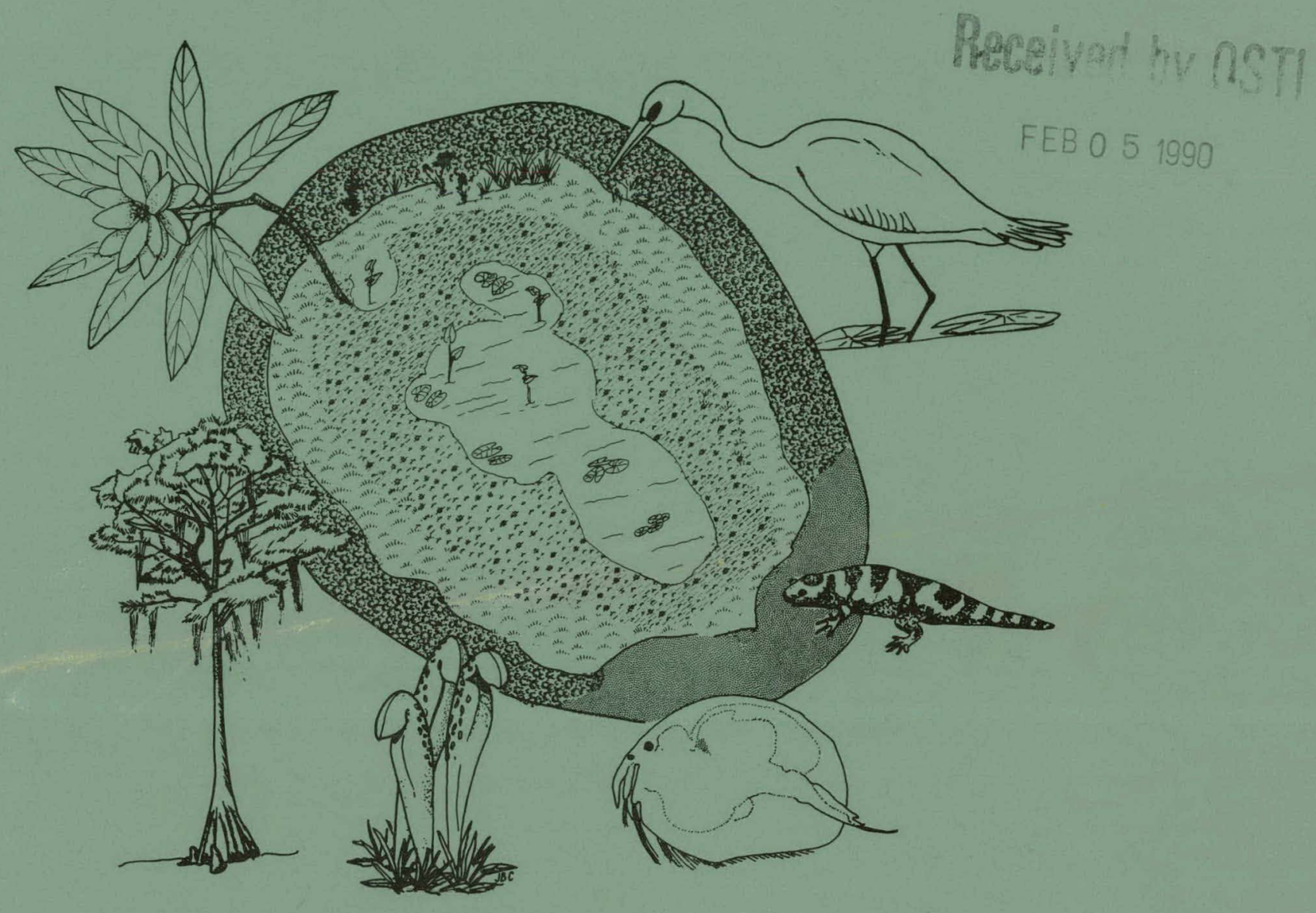

by John F. Schalles

Rebecca R. Sharitz

J. Whitfield Gibbons

Gordon J. Leversee.

and

John N. Knox

DO NOT MICROFILN

CUVER

\section{9}

A Publication of the Savannah River Plant National Environmental Research Park Program 


\section{DISCLAIMER}

This report was prepared as an account of work sponsored by an agency of the United States Government. Neither the United States Government nor any agency Thereof, nor any of their employees, makes any warranty, express or implied, or assumes any legal liability or responsibility for the accuracy, completeness, or usefulness of any information, apparatus, product, or process disclosed, or represents that its use would not infringe privately owned rights. Reference herein to any specific commercial product, process, or service by trade name, trademark, manufacturer, or otherwise does not necessarily constitute or imply its endorsement, recommendation, or favoring by the United States Government or any agency thereof. The views and opinions of authors expressed herein do not necessarily state or reflect those of the United States Government or any agency thereof. 


\section{DISCLAIMER}

Portions of this document may be illegible in electronic image products. Images are produced from the best available original document. 


\section{The following pages are an exact representation of what is in the original document folder.}




\section{A PUBLICATION OF DOE'S SAVANNAH RIVER PLANT NATIONAL ENVIRONMENTAL RESEARCH PARK}

This report was prepared as an account of work sponsored by the United States Government. Neither the United States nor the United States Department of Energy, nor any of their contractors, subcontractors, or their employees, makes any warranty, express or implied or assumes any legal liability or responsibility for the accuracy, completeness or usefulness of any information, apparatus, product or process disclosed, or represents that its use would not infringe privately owned rights.

Copies may be ublained from:

March 1989 Savannah River Ecology Laboratory

Drawer E

Aiken, SC 29801

USA 
Carolina Bays of the Savannah River Plant,

Aiken, South Carolina

by

John F. Schalles

Creighton University

Rebecca R. Sharitz

J. Whitfield Gibbons

Gordon J. Leversee and

John N. Knox

Savannah River Ecology Laboratory

A Publication of the Savannah River Plant

National Environmental Research Park Program

1989

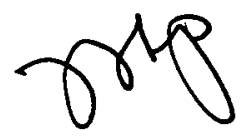


THIS PAGE

\section{WAS INTENTIONALLY LEFT BLANK}




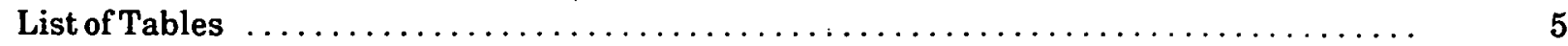

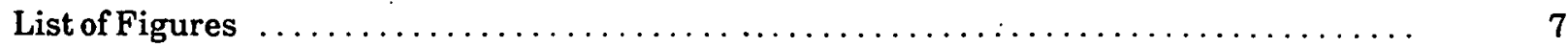

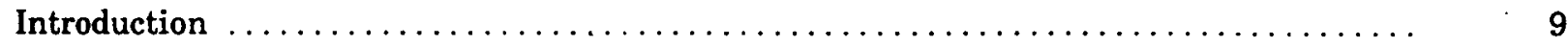

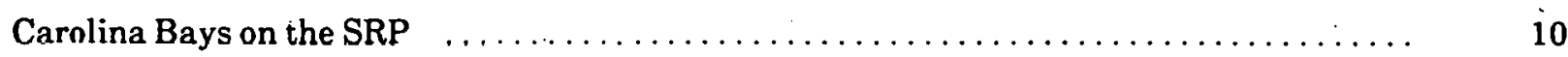

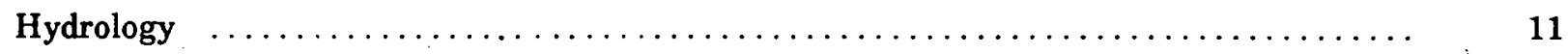

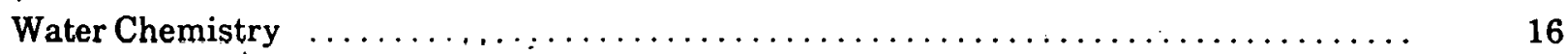

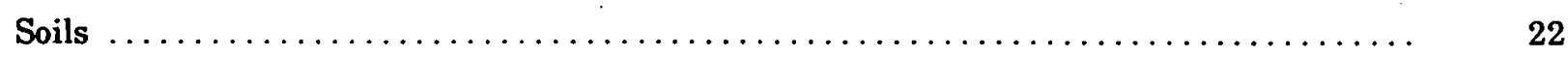

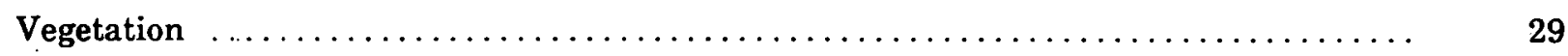

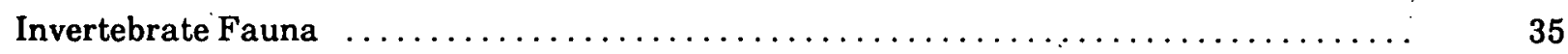

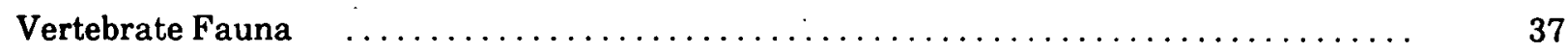

Recommendations for Research and Conservation $\quad \ldots \ldots \ldots \ldots \ldots \ldots \ldots \ldots \ldots \ldots \ldots$

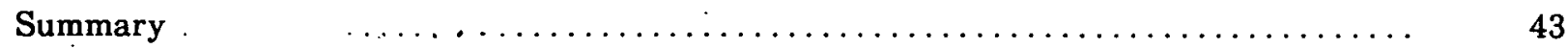

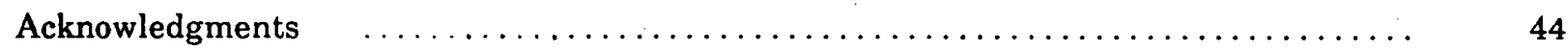

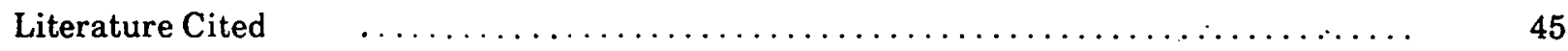

Appendix I. Areas and locatıuns of Carolina bays at the SRP $\ldots \ldots \ldots \ldots \ldots \ldots$

Appendix IIa: - Correlation matrix for physical-chemical data

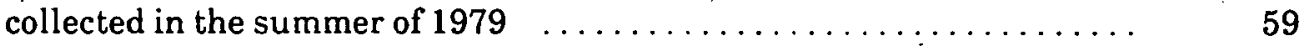

Appendix IIb. Correlation matrix for physical-chemical data collected in the winter of $1979-1980 \ldots \ldots \ldots \ldots \ldots \ldots \ldots \ldots \ldots .60$

Appendix III. Tree, shrub, herb, and Sphagnum species collected or observed in Carolina bays on the SRP $\ldots \ldots \ldots \ldots \ldots \ldots \ldots \ldots \ldots .61$

Appendix IV. . Reptile and amphibian species collected or observed in Carolina bays on the SRP $\ldots \ldots \ldots \ldots \ldots \ldots \ldots \ldots \ldots \ldots \ldots \ldots$ 


\section{List of Tables}

Page

Table 1. General features of Carolina bay depressions

Table 2. Cation balances for various southeastern coastal

plain surface water

Table 3. Detailed cation and anion analysis of surface

waters from six Carolina bays of the SRP and vicinity

Table 4. Correlation coefficients for 1979 and 1980 water

chemistry analyse

Table 5. Coefficients of variation for three surveys of Carolina

bays of the SRP and vicinity

Table 6. Hydrolab water chemistry values for eight stations at

Dry Bay on December 7, 1979

Table 7. Soil data for six Carolina bays on the SRP and adjacent Barnwell Nuclear Fuel Plant

Table 8. Pearson product-moment correlation coefficient matrix

for soil data from six Carolina bays of the SRP and

adjacent Barnwell County, SC

Table 9. Summary of soil chemistry analyses for six Carolina

bays on the SRP and Barnwell County, SC

Table 10. Pearson product-moment correlation coefficient. matrix for soil chemistry parameters in six Carolina bays on the SRP and in Barnwell County, SC

Table 11. Density of certain insect orders, oligochaetes, and isopods determined by artificial substrate sampling at

Rainbow and Sun Bays

Table 12. Utilization of Carolina bay habitats by small vertebrates. 


\section{INTRODUCTION}

One hundred ninety-four confirmed or suspected Carolina bays have been identified on the Savannah River Plant (SRP) in South Carolina. These natural, shallow depressions occur on nonalluvial, interstream areas of the SRP (Figure 14). Carolina bays contain hydric or mesic communities and range from lakes to shallow marshes, herbaceous bogs, shrub bogs or swamp forests (Wharton 1978). A Carolina bay can generally be distinguished from other southeastern U.S. coastal plain wetlands on the basis of several unique features (Table 1). An elliptical contour with

Table 1. General features of Carolina bay depressions (all features may not apply to all bays).

- Naturally occurring shallow depressions of upland interstream areas of the southeastern Coastal Plain.

- 30,000-100,000 years old (or older).

- Elliptical or ovoid.

- Northwest/southeast orientation of the long axis.

- Complete or breached low, sandy marginal rims with greatest development on the southeastern margin.

- Depression partially filled with inorganic clays and silts and/or organic peats.

- Continually or seasonally inundated wetlands in the depression. Fires may periodically remove organic accumulations.

northwest to southeast alignment of the long axis and the frequent presence of a marginal sand rim are perhaps the most useful diagnostic features. Conspicuous environmental features include fluctuating water levels and concomitant changes in chemical and biological variables such as dissolved ion concentrations, peat accumulation, and vegetation composition.

The geology and geomorphology of Carolina bay depressions were comprehensively described by Johnson (1942) and Prouty (1952) and were reviewed by Hutchinson (1957), Siple (1967), Price (1968), Schalles (1979), and Sharitz and Gibbons (1982). The ecological history and long-term succession of the bays and their surrounding terrestrial vegetation were addressed by Wells and Boyce (1953), Frey (1953, 1955), and Whitehead (1973) and were reviewed by Schalles (1979). Carolina bays are apparently pre-Holocene in age (Frey 1953, Whitehead 1973). Some contain lakes, although surface water levels have gradually decreased as the bays slowly fill with sediments and peat and as the surrounding groundwater levels decrease through local stream excision. Oxidative decomposition and fires during droughts have kept many bays from completely filling with peat.

Although much work has focused on the geology of Carolina bays, the composition and characteristics of their soils are described for relatively few sites. Many bays are reported to contain extensive organic deposits, whereas others are considered to be clay-based (hard-bottomed), with more poorly developed organic layers. Buell $(1939,1946)$ and Wells and Boyce (1953) described several Carolina bays in North Carolina which had peat deposits as thick as $4.5 \mathrm{~m}$. Peat is a high quality, exploitable energy source with an average ash content of $4 \%$ and heating value of $23.3 \mathrm{MJ} / \mathrm{kg}$ (Ingram and Otte 1981). Gamble et al. (1977) used auger drilling to examine depositional features of surface sediments in North Carolina sites. They found evidence of two sand rim types: primary rims which edged the initial depressions and sometimes exhibited pedogenic soil development, and secondary rims which were formed by shoreline beach processes that reworked sand deposits of apparent aeolian origin. Bryant and McCracken (1964) and Bliley and Pettry (1979) analyzed soil texture and mineralogy for Carolina bay sites in North Carolina and the eastern shore of Virginia. Mineral soils were generally sandy loams; sands and silts were predominantly quartz. Based on limited sampling, clays of the depressions seemed to be largely kaolinite, vermiculite, and vermiculite-chlorite intergrades with lower and variable levels of montmorillonite, gibbsite, and mica (Ingram et al. 1959, Bliley and Pettry 1979). 
Carolina bay water and soils display a moderately acidic ombrotrophic (i.e. precipitationdominated) chemistry reflecting a dystrophic status (Schalles 1989). Primary productivity estimates are few, but a general pattern of low to moderate production is revealed (Frey 1949, Woodwell 1958, Tilly 1973, Schalles and Shure 1989). Topographic relief and site hydrology are the major determinants of vegetational composition. Average water level, water level amplitude, and the timing and duration of flood events may be good predictors of bay community types (Wharton 1978, Schalles 1979). The flora and fauna characteristic of Carolina bays appear well adapted to fluctuating water levels, dryouts, and fires.

Fires during severe droughts are an important factor in the community composition of Carolina bays (Buell 1946, Wells and Whitford 1976, Wharton 1978, Christensen et al. 1981, Hodge 1985). Succession proceeds in the absence of fire as peat buildup alters the topography and new species invade. However, growing peat deposits become increasingly vulnerable to fire during dry periods. Discrete fire paths may induce topographic discontinuities and can result in less predictable spatial patterns in vegetation. Fire directly affects wetland soils by increasing $\mathrm{pH}$ and releasing nutrients from accumulated plant debris. Plant species diversity often increases and flowering and productivity of herbaceous species are stimulated following a fire. If fires are intense or frequent, woody species are removed, creating herbaceousdominated wetlands. Thus, alternating buildup and breakdown of the organic substrate may induce cyclic successional patterns.

The role of cultivation disturbance was discussed by Hodge (1985) in a study of eight herbaceous Carolina bays on and adjacent to the SRP (Aiken and Barnwell Counties). Ditching and draining, usually accompanied by cultivation, were frequent. One common effect of these practices within the bays was an increase in Panicum hemitomon or Leersia hexandra which resulted in almost pure stands. This is evident in both Ellenton Bay (Site 176) and Woodward Bay (Site 67). Although these bays have not been disturbed since 1951 , both were intensively cultivated in the 1930 s and 1940s.

Semi-aquatic fauna are characteristic of Carolina bay wetlands (Sharitz and Gibbons 1982).
Carolina bays can be considered disconnected, mesic or hydric "islands" in the sandy, coastal plain interfluves which provide habitat for many species. The bays are biotically coupled to local terrestrial habitats by serving as sites of amphibian reproduction and larval development (Patterson 1978, Bennett et al. 1979, Sharitz and Gibbons 1982) and by providing forage and water for upland wildlife. The habitat diversity of bay depressions promotes distinct avian assemblages; wet depressions provide refugia for migratory waterfowl (Mayer et al. 1986).

The objectives of this National Environmental Research Park study were to inventory the Carolina bays on the SRP, summarize descriptive information collected to date on abiotic and biotic properties, and provide recommendations for future research and conservation.

\section{CAROLINA BAYS ON THE SRP}

An inventory of Carolina bays on the SRP was made by examining color infrared photography (scale 1:15,840). One hundred ninety-four confirmed or suspected bays were identified (Figure 14 . Appendix I) and each bay was assigned a number and its position was located on a topographic map of the SRP (U.S.G.S. 1:48,000). Identification number, name (if known), location, wetland surface ared (from Shields et al. 1982), and habitat type of each bay are presented in Appendix I.

Carolina bays are distributed in clusters or broad bands across the SRP (Figure 14). Lowest densities occur in the northeastern section. The bays occur at elevations ranging from 120 to 340 feet $(36$ to $104 \mathrm{~m})$. The surface areas of bays on the SRP range from less than 0.3 acre $(0.1 \mathrm{ha})$ to about 125 acres (50 ha). A number of small wetlands with circular outlines exist on the SRP. These areas, which may be small Carolina bays, are especially numerous near the floodplain of the Savannah River on the southwestern portion of the SRP. When included in Appendix I, such sites are generally listed as suspected bays. As many as several dozen small wetlands were not listed because they appear to lack elliptical shapes or a northwest to southeast orientation of the long axis (see criteria in Table 1). Aerial photography from the 1940 s reveals that Sites 96,97 , and 98 (Figure 14) may be remnants of a very large bay covering about 550 acres ( 220 ha). 
The median size of the SRP bays is about 2 acres $(0.8$ ha; Figure 1); only 15 sites exceed 10 acres (4 ha). Although some of the SRP bays occur in close proximity to one another (e.g. Sites 24 and 25, 91 and 92), no examples were found of the overlapping bay depressions reported by Johnson (1942) or Prouty (1952).

Carolina bays on the SRP have mineral soils with little or no peat accumulation. Most of the bays contain water, at least seasonally or in some years. Frey (1950) observed that such "hard-bottomed" bays in North Carolina occur primarily on the upper coastal plain terraces and that many of these higherelevation sites have been cleared and drained for agriculture. About $80 \%$ of 168 bays (not including SRP sites) identified in Barnwell County, SC have farming activity on adjacent lands and at least $20 \%$ have been drained and farmed (Schalles, personal observation). Draining and clearing of southeastern coastal plain wetlands continues and many remaining nonagricultural bays are vulnerable to exploitation for agriculture and silviculture (Richardson et al. 1981, Sharitz and Gibbons 1982). Carolina bays on the SRP have remained largely undisturbed since 1950 and are valuable examples of these ecosystems.

\section{HYDROLOGY}

Carolina bays represent the only abundant natural lentic systems on the Georgia-Carolina Coastal Plain; their hydrology has been inadequately studied. Water chemistry of undisturbed Carolina bays on the SRP is typical of precipitation-dominated, ombrotrophic systems (Schalles, in press). Surface inflow channels are generally absent. Drainage channels occur with some frequency and many appear to have been manmade or modified. Today, through disuse, most of these channels are partially filled with sediments and discharge only during periods of extremely high water.

Water levels in three extensively studied SRP bays are compared in Figure 2. Although the water levels of these bays were grossly related to amount of precipitation, the amplitude and timing of changes differed. For example, Ellenton Bay (Site 176) and Thunder Bay (Site 83) had similar overall patterns, whereas Rainbow Bay (Site 189) had much greater fluctuation in water level (Figure 2).
Schalles (1979) found that maximum water level fluctuations over an annual cycle in 1974-1975 were between 35 and $83 \mathrm{~cm}$ in six local bays. Hodge (1985) noted a similar range of $25-63 \mathrm{~cm}$ in the water level changes of eight SRP and Barnwell County bays during 1984-1985. Some differences in water level among bays are caused by differences in the amount of precipitation received, particularly during seasons of localized thunderstorms. Higher ratios of surface area to storage volume could result in proportionately higher losses to seepage in smaller bays. Strong seasonal differences in water loss rates were found in Ellenton and Thunder Bays (Figure 3) and appeared related to seasonality in evapotranspiration rates. Differences in water level and amplitude of bays may also be caused by local differences in groundwater behavior and by differences in the permeability of underlying strata. Wells and Boyce (1953) found strong evidence for much lower levels of lake-groundwater exchange in Black Lake (renamed Bay Tree Lake) versus White Lake in North Carolina.

Continuous or temporary connection to nearsurface groundwater is probably a common feature of Carolina bays. Comparisons of surface water levels to the piezometric levels in four adjacent monitoring wells (Schalles and Cahill, unpublished; Figure 4) revealed conditions favorable to almost continuous subsurface seepage loss and periodic groundwater recharge at Thunder Bay. Schalles (1979) proposed that most groundwater-surface water interactions occur laterally, around the margins of the depressions, and that these connections are often lost during periods of low water levels. A similar hydrologic model was proposed by Heimbery (1976) for shallow cypress. dome depressions in central Florida. An impervious clay lens appears to underlie many of the SRP bays (see SOILS section). Soils in the center of the bays contain higher percentages of clays and silts than those closer to the rims. Consequently, soils in the center are less permeable and more poorly drained (Hodge 1985). Because site-specific hydrology is a controlling variable in Carolina bay ecosystems, detailed hydrological measurements and modelling should be a high priority for future research.

All Carolina bays on the SRP dry out periodically. Many of the smaller bays contain surface water only during wet seasons, whereas some of the larger depressions (e.g. Craig's Pond, Site 77, and Ellenton Bay) dry up only during prolonged drought. Ellenton Bay experienced severe 


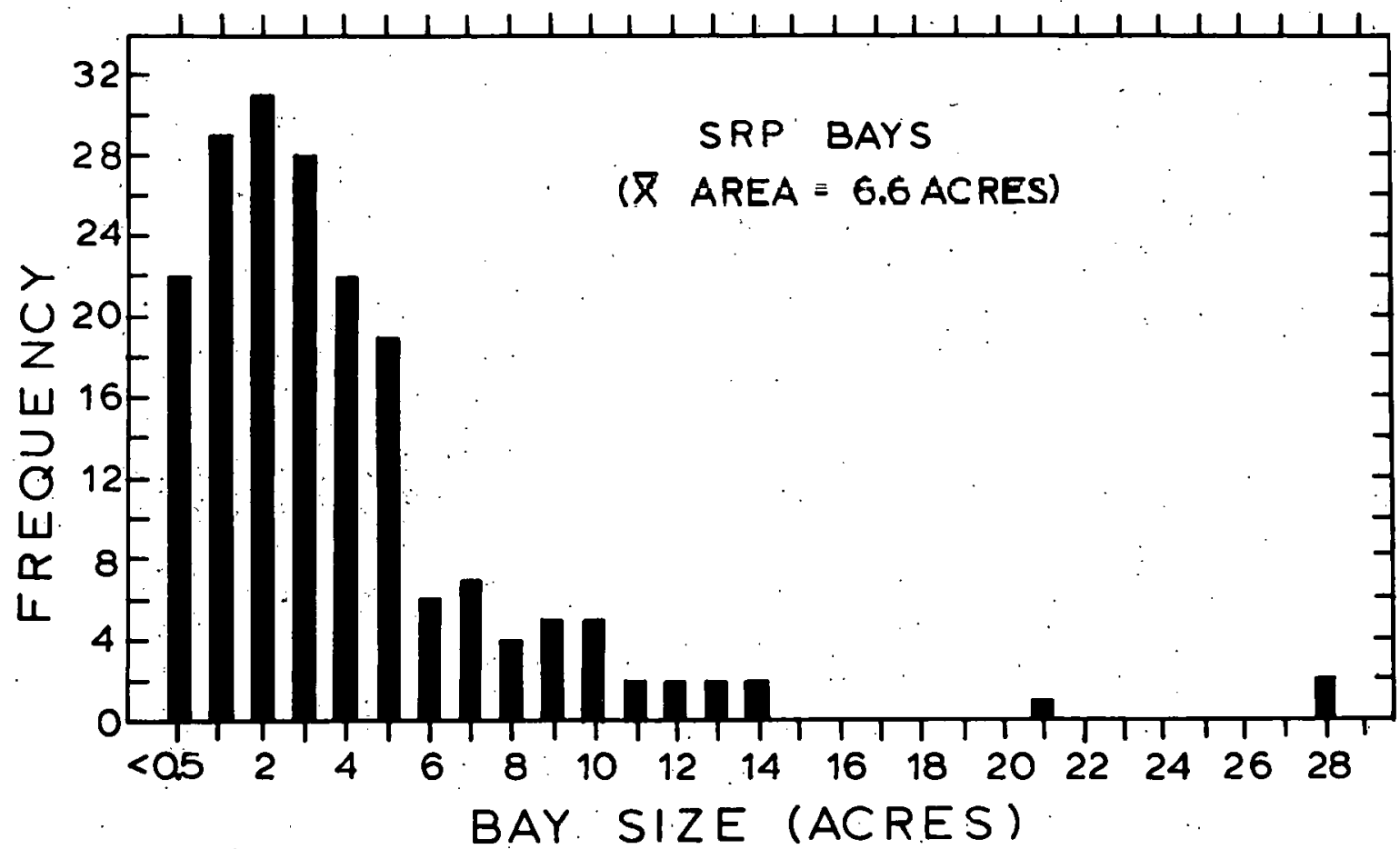

Figure 1. Size distribution of the Carolina bays of the SRP (acreage data from Shields et al. 1982). 


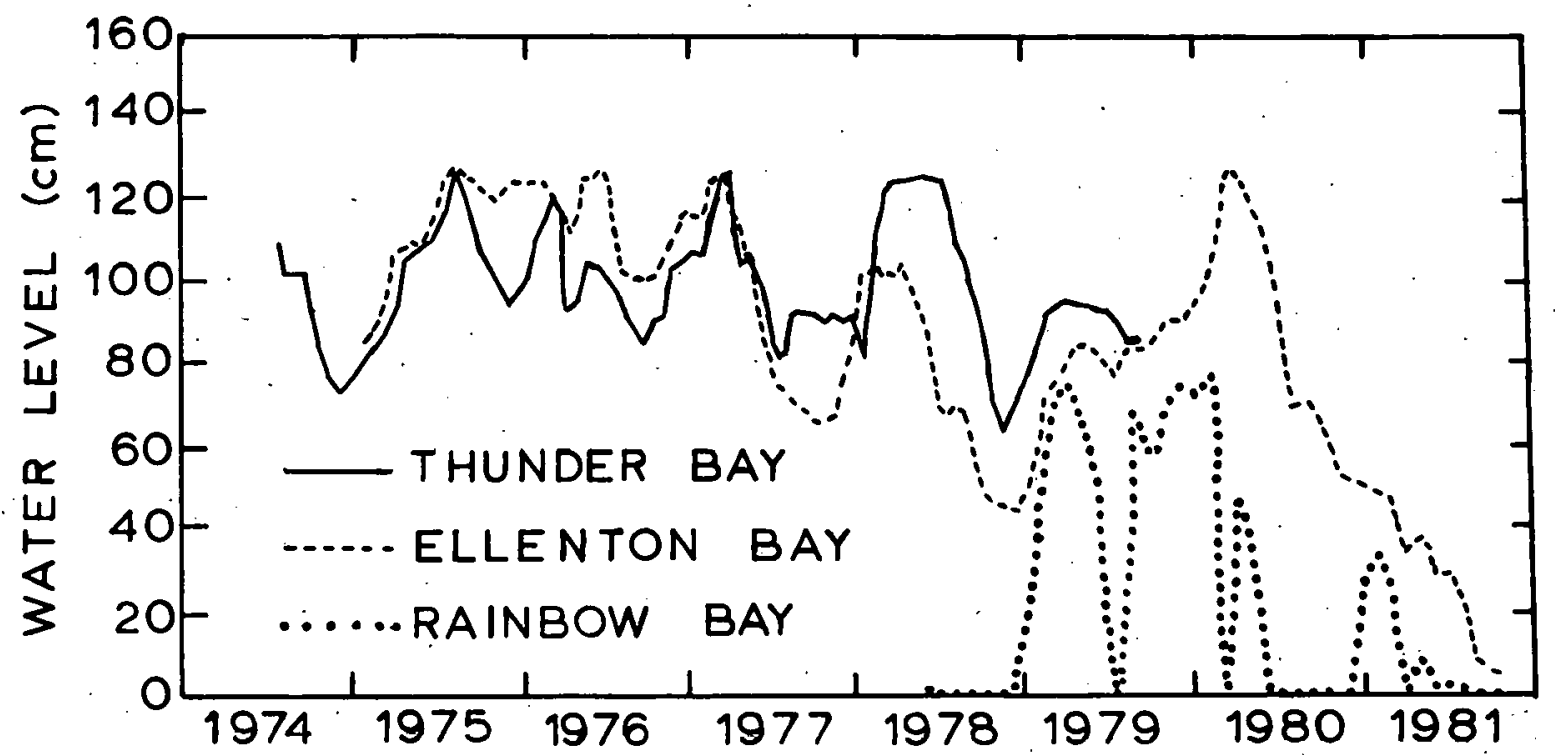

Figure 2. Surface water levels of three Carolina bays at the SRP (Thunder Bay, Site 83, data from Schalles and Shure 1989; Ellenton Bay, Site 176, and Rainbow Bay; Site 189, data from Sharitz and Gibbons 1982). 


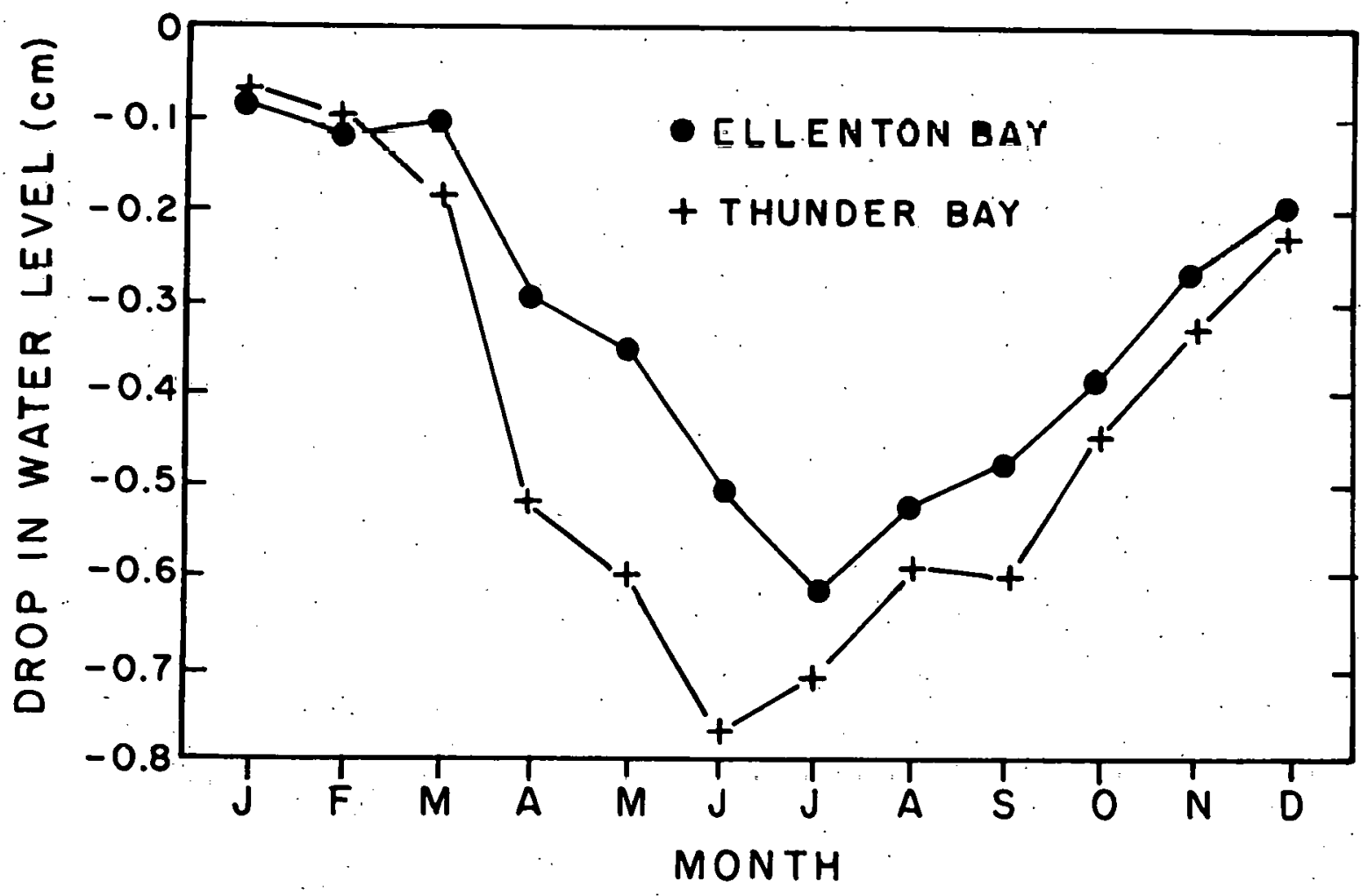

Figure 3. Daily water loss rates for Ellenton Bay (Site 176) and Thunder Bay (Site 83). Ellenton Bay data from Sharitz and Gibbons 1982, Thunder Bay data from Schalles and Cahill, unpublished. 


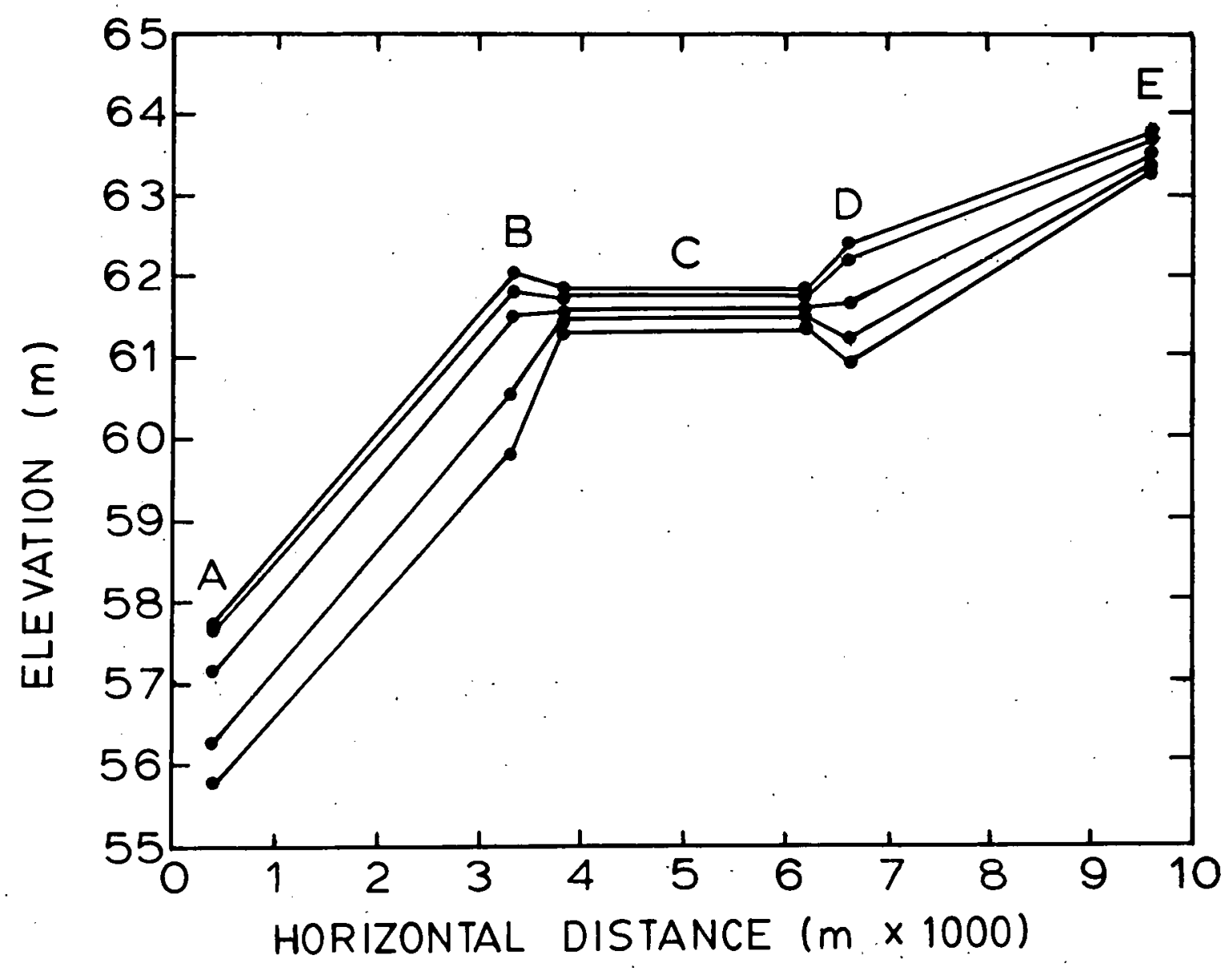

Figure 4. Comparison of surface water level in Thunder Bay (Site 83) versus water levels in four adjacent groundwater observation wells on five dates representing the range of water level stages encountered between 1976 and 1978. (Elevations in meters, National Geodetic Vertical Datum of 1929 ; C = bay surface; A, B, D, and E = observation wells. Well $E$ is the farthest upslope and is located adjacent to Gate 19 on SRP road B-7. Unpublished data of Schalles and Cahill.) 
drying (only a few deep holes held water) during droughts in 1968 and 1981 (Sharitz and Gibbons 1982) and in 1987 and 1988 (Pechmann, personal observation). Craig's Pond was dry to at least $20 \mathrm{~cm}$ below the surface in 1988 (Landaal, personal observation).

\section{WATER CHEMISTRY}

Several surveys of surface water chemistry in SRP Carolina bays have been made. For this report, two groups of analyses were performed: replicate samples from sixteen sites on single collection dates were obtained in the summer of 1979 and a more comprehensive survey of eighteen sites (including thirteen sites not visited the previous summer) was conducted between November 1979 and April 1980. Additionally, Schalles (1979) analyzed water samples between August 1974 and August 1975 from six bays on the SRP and the adjacent Barnwell County Industrial Park. Values for inorganic parameters were determined with standard atomic absorption spectrophotometry and titrametric procedures. A Beckman carbon analyzet was used for total carbon and inorganic carbon analyses. Redox (relative values), dissolved oxygen, temperature, conductivity, and $\mathrm{pH}$ measurements were made during the eighteen-site comparison with a Hydrolab in situ water quality analyzer. Schalles (1979) used a Yellow Springs Model 54 oxygen analyzer for more frequent measurements of oxygen and temperature vertical profiles and for diel studies.

The surface waters of the surveyed bays were acidic (pH 3.8 - 5.5) with very low levels of calcium and total inorganic solutes (conductivities of 20-40 umhos). Bay waters had low to moderate color and dissolved organic carbon (mean $=22 \mathrm{mg} / \mathrm{l}$ ). These characteristics are similar to those reported for the Okefenokee Swamp (Auble 1984), North Carolina bay lakes (Frey 1949), lower coastal plain pocosins (Daniel 1981), a Florida cypress dome (Dierberg and Brezonik 1984), and lakes and ponds of the New Jersey Pine Barrens (Patrick et al. 1979). The moderate levels of color and dissolved organic carbon (DOC) in the bays can be attributed to the low calcium levels, abundance of living and decaying plant materials, and the shallow depths of the ponds.

No single element dominates cations in the bay ponds. Calcium was the most abundant cation
$(25 \%$ of total meq/l) in the 1980 survey of eighteen SRP bays. However, sodium, magnesium, and hydrogen ions were also significant (Table 2). The relatively high monovalent/divalent cation ratios, low total inorganic solutes, and occurrence of moderate acidity and dissolved organic carbon in SRP bays are likely the result of sea salt contributions to atmospheric chemistry in the region, very restricted watersheds with sandy, leached soils, periodic exchanges with low solute strength shallow groundwater, and high nutrient retention by vegetation (Schalles 1989). Cation balances in other southeastern wetlands were similar to those in SRP bays, but some differences existed. Sodium dominance was seen in the impounded waters of the SRP and othor southeastern softwater wetlands (Table 2). Overall, the SRP bays had lower total cation levels than did these othcr coastal plain areas. Manganese concentrations in SRP bays were about one order of magnitude greater than the freshwater, global average $(0.0013 \mathrm{meq} / \mathrm{l})$ reported by Livingston (1963). A possible source of the manganese is conifer litter (Wetzel 1983) from marginal pine forests and concentrations in the ponds may attest to the importance of exchange pathways between these ponds and adjacent terrestrial habitats. However, local geologic features could also account for the manganese levels. A 1988 regional survey of bay surface water chemistry found that elevated manganese levels were mostly associated with upper coastal plain sites of the Aiken Plateau area (Newman and Schalles, unpublished).

Detailed chemical analyses of three SRP bays and three others in the vicinity of the plant (Table 3) were made as part of a 1988 regional survey of 53 sites. Overall, solute levels were higher than levels seen in previous SRP bay surveys. Potassium levels were notably higher and hydrogen ion levels lower. A very dry period during the early and mid-1980s and corresponding ecosystem responses may account for these differences (see section on bay chemistry dynamics below). Chloride was the dominant inorganic anion, with sulfate second in abundance (Table 3). Dissolved organic carbon averaged 14.1 $\mathrm{mg} / \mathrm{l}$ and accounted for $39 \%$ of the total anionic charge. Dissolved silica values were moderate but quite variable. The dilute, acidic chemistry is a probable indicator of moderate to severe nutrient limitations in the bay ponds. Nutrient spiking experiments in nearby Risher Pond (an abandoned farm pond) revealed that sulfate introduction alone could stimulate $\mathrm{C}-14$ fixation and that combinations 
Table 2. Cation proportions for various southeastern coastal plain surface waters (softwater, lentic systems). Iron and manganese were probably present as colloids and thus do not contribute to total cation charge.

\begin{tabular}{ccccccc}
\hline $\begin{array}{c}\text { Cation } \\
(\% \text { meq/l) }\end{array}$ & $\begin{array}{c}\text { This } \\
\text { Report }\end{array}$ & $\begin{array}{c}\text { SRP } \\
\text { Farm } \\
\text { Ponds1 }\end{array}$ & $\begin{array}{c}\text { North } \\
\text { Carolina } \\
\text { Pocosins }\end{array}$ & $\begin{array}{c}\text { Georgia } \\
\text { Okefenokee } \\
\text { Swamp3 }\end{array}$ & $\begin{array}{c}\text { Florida } \\
\text { Cypress } \\
\text { Dome4 }\end{array}$ & $\begin{array}{c}\text { Virginia } \\
\text { Lake Drummond, } \\
\text { Dismal Swamp5 }\end{array}$ \\
\hline $\mathrm{Ca}^{++}$ & 24.4 & 18.6 & 34.9 & 7.6 & 25.4 & 38.2 \\
$\mathrm{Mg}^{++}$ & 17.4 & 21.0 & 16.6 & 9.4 & 20.1 & 16.9 \\
$\mathrm{Na}^{+}$ & 23.7 & 51.6 & 36.6 & 45.9 & 38.3 & 31.3 \\
$\mathrm{~K}^{+}$ & 5.6 & 7.4 & 2.6 & 2.0 & 1.6 & 9.4 \\
$\mathrm{H}^{+}$ & 18.2 & & 9.2 & 32.3 & 5.7 & 1.8 \\
$\mathrm{Fe}^{++}$ & 5.9 & & & 2.6 & 3.4 & 2.4 \\
$\mathrm{Mn}+$ & 4.9 & & $<0.1$ & 1.4 & 1.4 & \\
$\Sigma(\mathrm{meq} / 1)$ & 0.261 & & 0.573 & 0.392 & 0.561 & 0.875
\end{tabular}

1 Tilly (1975), 2 Daniel (1981), 3 Auble (1984), 4 Dierberg and Brezonik (1984), 5 Lichtler and Walker (1979).

of several ions $\left(\mathrm{NO}_{3}^{-}, \mathrm{PO}_{4} \equiv \mathrm{Ca}^{++}\right.$, and $\left.\mathrm{K}^{+}\right)$had variable but stimulatory results (Polisini et al. 1970). A more detailed analysis of major and trace nutrients and their significance to primary production is needed for Carolina bay ecosystems.

The acidic nature of the bay surface waters suggests a dystrophic condition. The acidity seems largely related to biological phenomena and low regional alkalinities. Interestingly, sphagnum moss, often implicated in bog acidity (Clymo 1964), is uncommon or absent from SRP bay communities. Organic acids and the metabolic products of sulfur bacteria (both chemosynthetic and photosynthetic) may be important sources of hydrogen ions in the bay ponds (Schalles 1979).

An increase in solute concentrations was noted in Bays 64 and 120 during a dry period in 1974; however, a much more pronounced increase was noted in early refilling stages. Conductivity values at these sites were about $600 \%$ greater in refilling stages than at similar water levels just prior to complete drying (Schalles 1979). This was attributed to an isolation of the ponds from groundwater exchanges, leaching of solutes from dead vegetation during refilling, and increased mineralization rates of soil detritus. Ponds that did not dry out had more modest solute response to changing water levels. Regression models of conductivity versus water level accounted for between 34 and $78 \%$ of the variance in conductivity for five sites with no surface exchanges, whereas no conductivity/water level relationship was found in a local bay pond at the Barnwell Industrial Park that received substantial storm runoff and surface flushing (Schalles 1989). Examination of individual solutes revealed that potassium, magnesium, and calcium had much higher negative correlations with water level than did sodium or DOC. In marsh 
habitats of the Okefenokee Swamp, Bosserman (1979) found that water level had stronger correlations with potassium and magnesium than with calcium, sodium, or $\mathrm{pH}$. The lack of significant correlations between water level and sodium is puzzling. Sodium is a conservative ion (Wetzel
1983) and one would anticipate a direct concentration effect with decreasing water level and surface volume. Although a lack of correlation between DOC and water level seems to exist in SRP sites, data obtained from four bays in 1979-80 (Figure 5) reveal seasonal behavior. DOC changes

Table 3. Detailed chemical analysis, including anion/cation charge balance, for surface waters in six Carolina bays sampled as part of a regional survey in January 1988.1

\begin{tabular}{|c|c|c|c|c|}
\hline Variable & $\overline{\mathbf{x}}(\mathbf{r a}$ & $\begin{array}{l}\text { Ige, by sites) } \\
\mathrm{mg} / 1\end{array}$ & $\begin{array}{c}\bar{x} \\
\text { meq/1 }\end{array}$ & $\begin{array}{c}\bar{x} \\
\% \text { meq }\end{array}$ \\
\hline D.O.C. 2 & 14.09 & $(8.08-21.71)$ & 0.155 & 39.0 \\
\hline $\mathrm{Cl}^{-}$ & 4.94 & $(3.44-7.99)^{\circ}$ & 0.139 & 35.0 \\
\hline $\mathrm{SO}_{4}^{--}$ & 3.32 & $(0.50-10.34)$ & 0.069 & 17.4 \\
\hline $\mathrm{HCO}_{3}$ & 2.07 & $(0.13-6.89)$ & 0.034 & 8.6 \\
\hline Anions $(\Sigma)$ & -- & & 0.397 & 100.0 \\
\hline $\mathrm{Na}^{+}$ & 3.08 & $(0.82-6.64)$ & 0.134 & 32.8 \\
\hline $\mathrm{Ca}^{++}$ & 2.12 & $(0.72-4.53)$ & 0.106 & 26.0 \\
\hline $\mathbf{K}^{+}$ & 3.83 & $(1.09-14.5)$ & 0.098 & 24.0 \\
\hline $\mathbf{M g}^{++}$ & 0.78 & $(0.49-1.25)$ & 0.064 & 15.7 \\
\hline $\mathrm{H}^{+}$ & 0.006 & $(0.001-0.013)$ & 0.006 & 1.5 \\
\hline 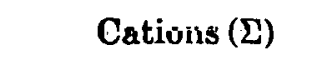 & -- & & 0.408 & IU்ப் \\
\hline Sp. Conductance 3 & 47.4 & $(28.6-98.2)$ & & \\
\hline $\mathrm{pH}$ & $5: 2$ & $(4.9-6.1)$ & & \\
\hline $\mathrm{SiO}_{2}$ & 2.82 & $(0.10-9.24)$ & & \\
\hline $\mathrm{Fe}$ (reactive) ${ }^{4}$ & 0.35 & $(0.28-0.63)$ & & \\
\hline Mn (reactive) 4 & 0.18 & $(0.09-0.32)$ & & \\
\hline
\end{tabular}

1 The sites were: Flamingo Bay (Site 3), Enchantment Bay (Site 40), Thunder Bay (Site 83), Mathis Lake in Aiken County, and Sister Lake and an unnamed site near Williston in Barnwell County. Four replicates were collected per site. Anions were determined with ion chromatography, metals. with atomic absorption spectrophotometry, silica.with molybdenum blue method (Newman and Schalles, unpublished)

2 dissolved organic carbon, charge estimated from the analysis of Perdue et al. 1984

3 in $\mu \mathrm{mhos} / \mathrm{cm}$

4 from acid-pretreated samples, may be largely colloidal and values were not used in the charge balance analysis 


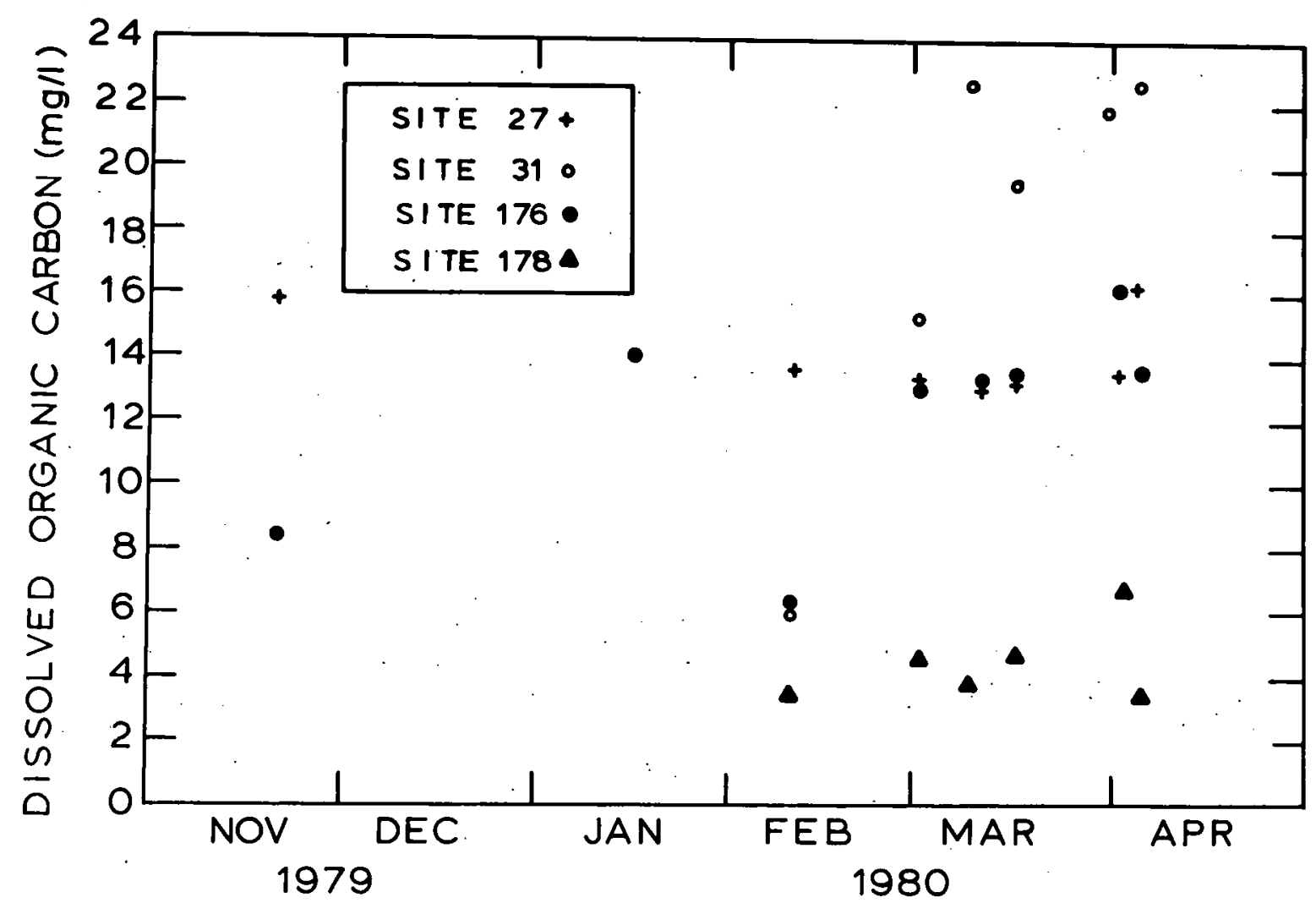

Figure 5. Dissolved organic carbon levels (average of two values per point) in four Carolina bays at the SRP (Site 27, Morse Code Bay; Site 31, Dry Bay; Site 176, Ellenton Bay; and Site 178, Asphalt Pond). See text for description of Asphalt Pond. 
may be more closely related to temperature and seasonal dynamics of biological processes than to evaporation. It should be noted that Site 178 (Asphalt Pond; Figure 5) is an anomaly, having been filled and paved with asphalt early in the history of the SRP, only to later have the pavement sink and the bay refill with water. This site, which has very low solute water, may function primarily as a precipitation collector with minimal groundwater exchanges and watershed contributions.

Relationships between variables measured in the 1979 and 1980 surveys were examined with product-moment correlation analysis (Table 4). Many of the significant correlations are related to similar behavior and cycling patterns (e.g. calcium and magnesium, iron and manganese) or dependency of some variables on others (e.g. conductivity on dominant ions, total carbon on organic carbon, $\mathrm{pH}$ on calcium, and iron on total organic carbon). Some variables such as potassium, oxygen, bay size, and bay elevation had few significant correlations (Appendix IIa and IIb). In general, many of the relationships are weak, even though statistically significant. Also, the correlations found in the surveys for this report are weaker than those found among the six sites studied in 1973-1974 (Schalles 1989).

In the three water chemistry analyses of SRP bays (1973-1974, 1979, and 1980), potassium exhibited the greatest overall variability (Table 5).

The seasonal dynamics of potassium and its responsiveness to change in water levels may make this ion a useful variable to monitor the overall status of bay sites. Iron and manganese also exhibited high variability, while magnesium and conductivity had comparatively low variabilities. The higher coefficients of variation for the six sites in the 1973-74 study are largely attributable to the inclusion of two disturbed sites at the Barnwell County Industrial Park (Table 5). These two sites received considerable surface runoff and sedimentation from a large construction area. The disturbed ponds experienced high flushing rates, vegetation damage, and burial of organic sediments. These disturbances resulted in less acidity, lower DOC concentrations and monovalent to divalent cation ratios, and higher inorganic solute concentrations and conductivities than undisturbed sites (Schalles 1989). These changes were attributed to increased calcium bicarbonate loading, reduced biotic influence on the chemical environment, and open hydrology.
The more extensive comparison of eighteen sites in the 1980 survey revealed some patterns in cation concentrations (Figure 6A-H). Sites 61 and 92 had the highest calcium, magnesium, and total cation concentrations (Figures 6A, B, H). Both sites contain swamp forests and typically have very shallow water levels. A lack of correlation existed between the total cation concentration and $\mathrm{H}+$ rankings (Figures $6 \mathrm{G}, \mathrm{H}$ ). The highest $\mathrm{pH}$ was found in Sites 31, 92, and 176 and the lowest in 77. No physical or biological features were apparent to explain the pH ranking. Evidence from sodium/calcium ratios (Gibbs 1970) and from multivariate discriminant analysis of chemical survey data strongly implicated site-specific hydrology and differences in shallow groundwater chemistry as major factors in observed intersite variability (Schalles 1989). Much more intensive and comprehensive chemical sampling is required to further document and explain spatial and temporal chemistry patterns.

Spatial and temporal variability in oxygen and temperature were noted in the bay ponds. Strong oxygen and temperature stratification often existed when emergent or floating-leaf vegetation was present, even in shallow waters (Figure 7). Bottom strata exhibited very low oxygen levels (less than $0.5 \mathrm{mg} / \mathrm{l}$ ) during most of the year Stratification and destratification can occur almost daily. Horizontal patterns were demonstrated with in situ Hydrolab measurements made in December 1979 in Dry Bay (Site 31). Highest oxygen values were found in shallow water with abundant filamentous algae while the lowest value was found in a macrophyte-shaded area with abundant detritus (Table 6). In general, bay pond margins had the greatest overall physical-chemical variability. Thunder Bay pond (Site 83) displayed marked seasonal patterns (Schalles 1989). Average water column oxygen values ranged from about 7 to $8 \mathrm{mg} / \mathrm{l}$ in midwinter to about 1.5 to $2 \mathrm{mg} / \mathrm{l}$ in late summer. Average water column temperatures varied from approximately $27^{\circ} \mathrm{C}$ in midsummer to $7^{\circ} \mathrm{C}$ in midwinter. The high spatial (both vertical and horizontal) and temporal (both daily and seasonally) variability in oxygen and temperature necessitate detailed measurements of these parameters before correlations with biotic and other abiotic variables can be established. 
Table 4. Correlation coefficients ( $r$ ) for 1979 and 1980 water chemistry analyses (extracted from correlation matrices in Appendix IIa and b).

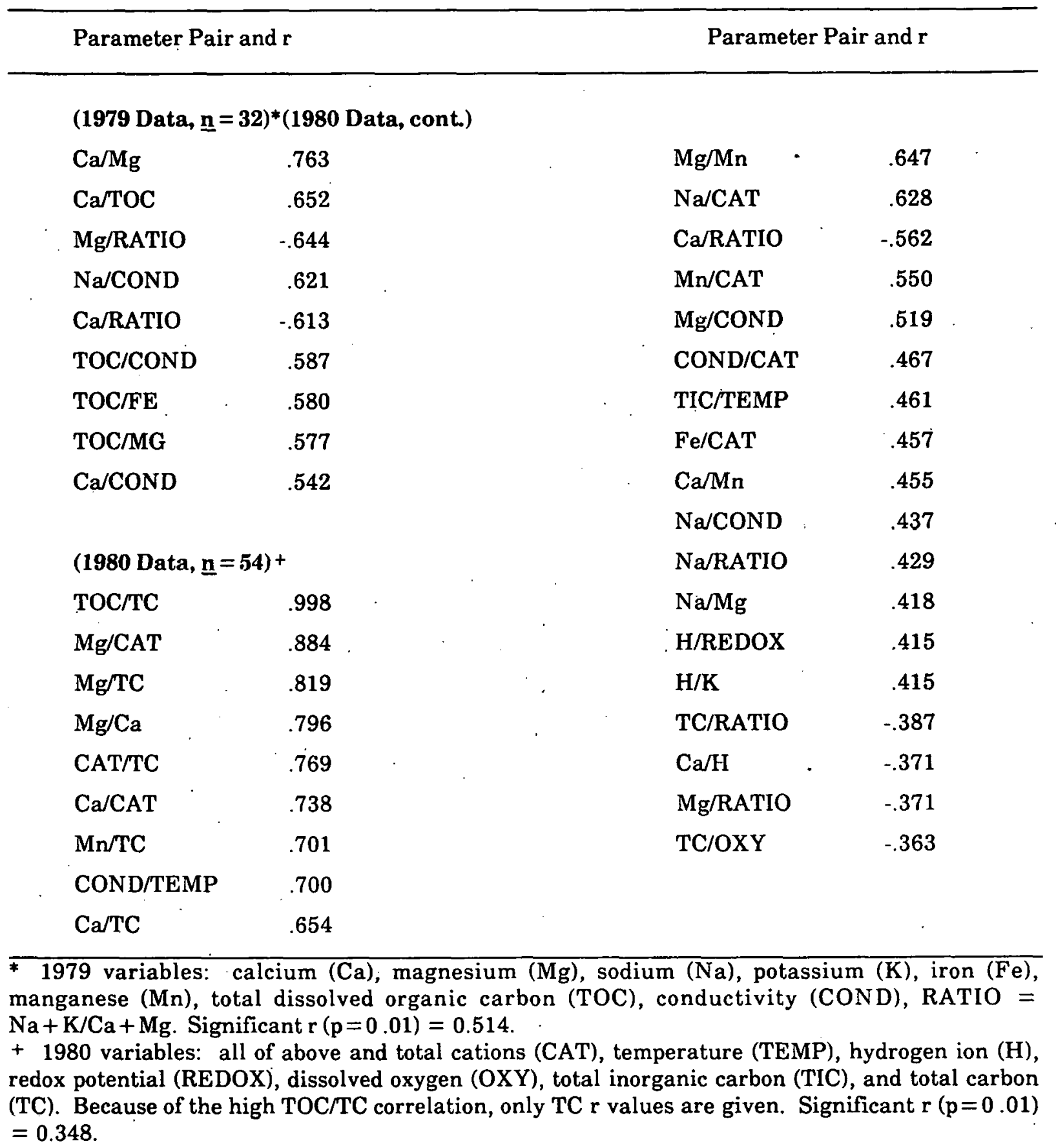




\section{SOILS}

Soils of Carolina bays are poorly studied. Bay soils generally grade from well-drained sands on the xeric rims to consolidated sandy loams in the wetland centers. Hodge (1985) observed two conditions in sandy surface soils of the bay rims and adjacent interbay areas on or near the SRP. In one condition, the surface sand was $75-150 \mathrm{~cm}$ thick and was underlain by a sandy clay loam (Blanton series). In the second condition, the surface layer was excessively drained sand with depths exceeding 2 meters (Lakeland series). Interior to the bay rims, Hodge found a narrow zone with loamy surface sands $15-35 \mathrm{~cm}$ thick overlying a sandy clay loam. horizon about $45 \mathrm{~cm}$ thick and a third horizon of about $75 \mathrm{~cm}$ composed of sandy loams or loamy sands. The central floors of most bays on or near the SRP have shallow, consolidated loamy soils which vary from $15-75 \mathrm{~cm}$ in thickness. A consolidated, gray clay hardpan is consistently found below the loamy stratum. Hodge (1985) determined that these hardpans averaged about $70 \mathrm{~cm}$ thick and that soils immediately below the hardpans were sandy clay loams. Organic horizons are generally thin, but often increase with increasing water depths and hydroperiods. The surficial mineral soils of the bay interiors are typically dark and contain numerous fine charcoal fragments indicating earlier fires (Schalles 1979).

Most soils occurring in the interiors of bays at the SRP and vicinity fit an Ochraquult classification (Hodge 1985). Ochraquult soils have thin, dark epipedons, thin to moderately thick argillic horizons, and base saturations of less than $50 \%$. Such soils are inundated for at least three months of the year and have poor drainage. Soils of the SRP bays are largely Rembert and Ogeechee series loams, hut also include Williman and Lumbec loamy sands (Hodge 1985). Interior to the sandy bay rims, soils of the following series are less frequently encountered: Duplin, Plummer, Faceville, Orangeburg, and Johnston (Hodge 1985).

Texture analysis (method of Boyoucous 1927) was performed on samples from the upper $20 \mathrm{~cm}$ of soil in the wetland communities of the six bays used in the 1973-74 comparative survey (Schalles 1979).

Table 5. Coefficients of variation (S.D./ $)$ for three surveys of Carolina bays at the SRP and vicinity.

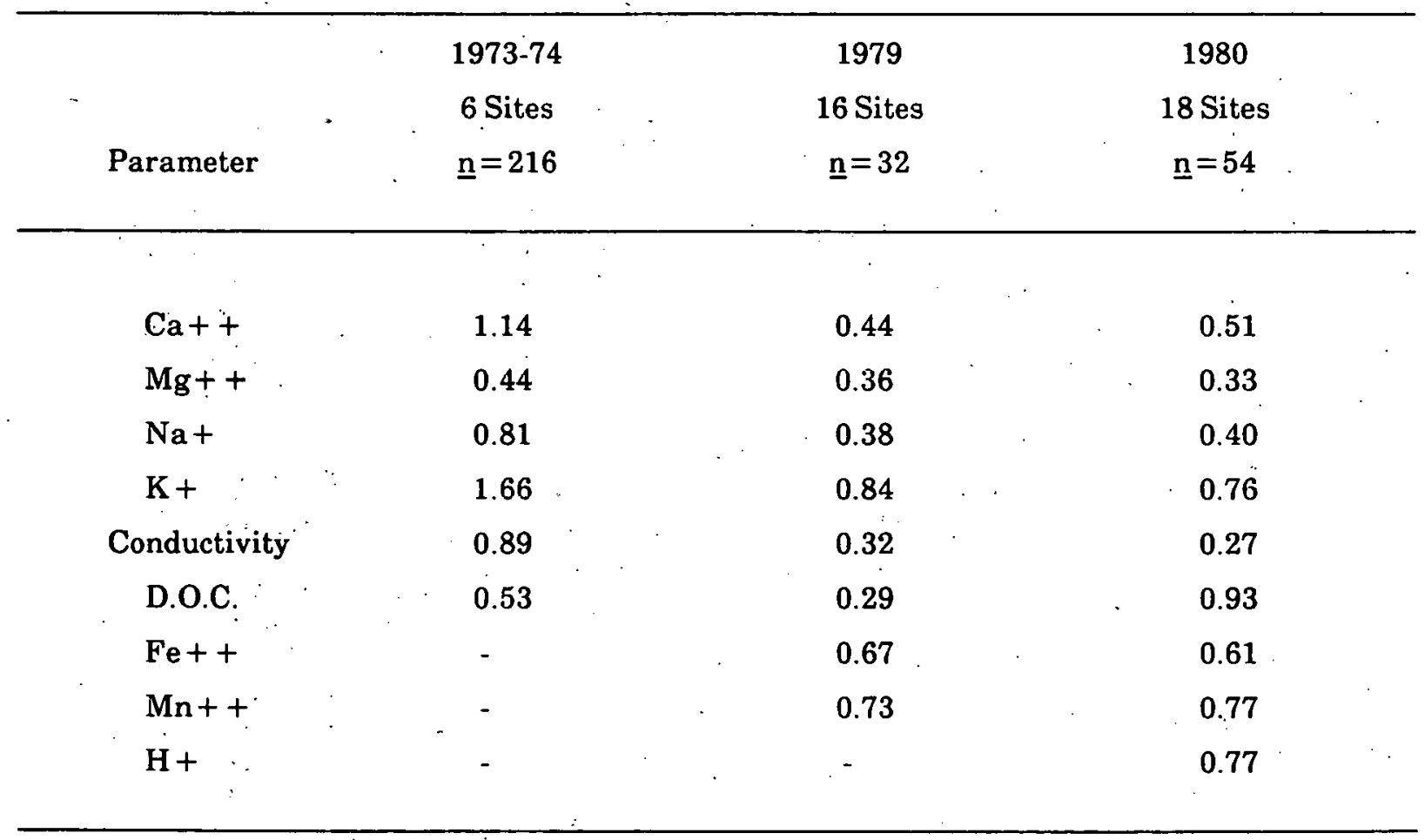



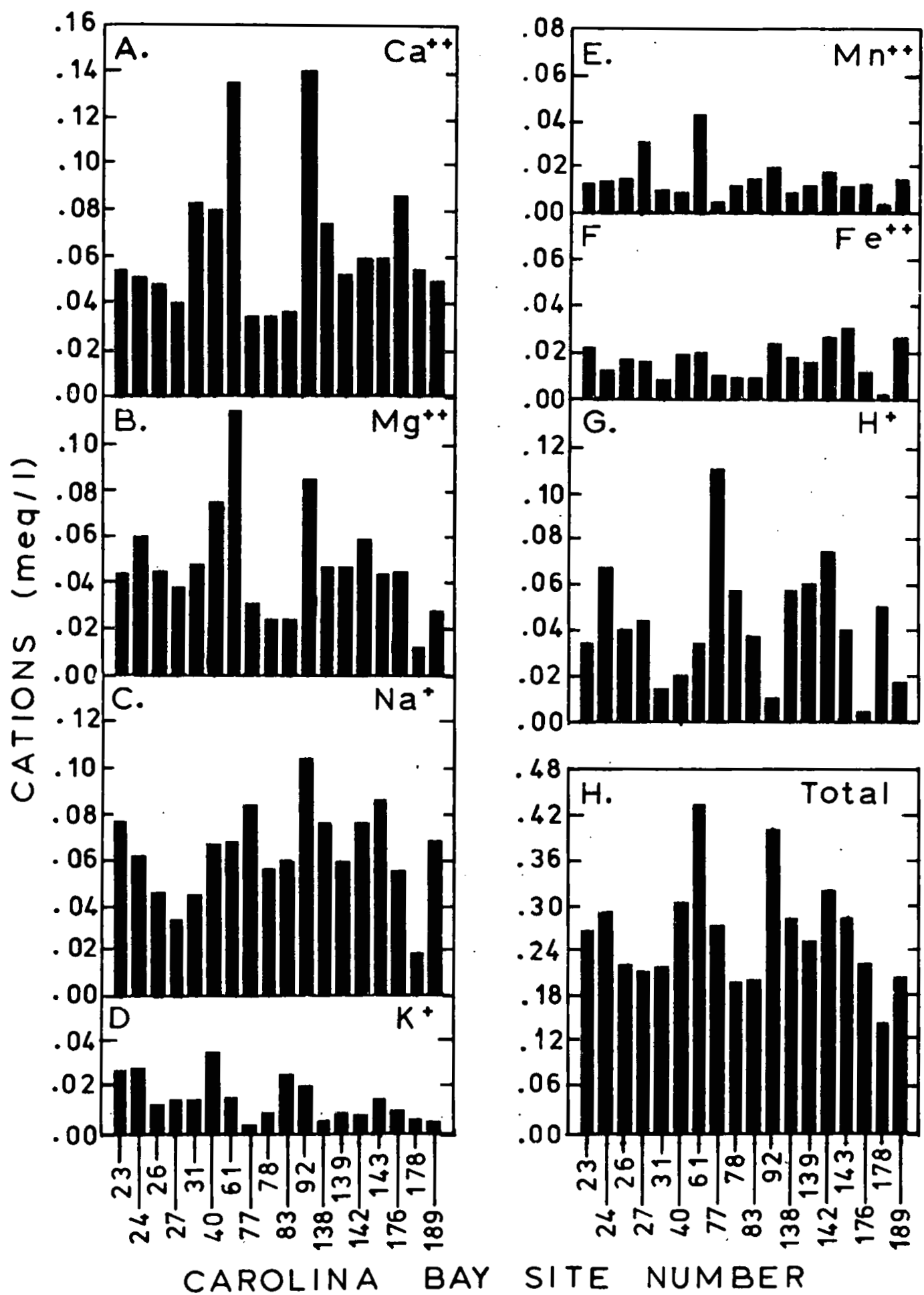

CAROLINA BAY SITE NUMBER

Figure 6A-H. Average $(\underline{n}=3)$ surface water concentrations $(\mathrm{meq} / \mathrm{l})$ of seven cations and total cations measured between January and March 1980 in 18 Carolina bays at the SRP (see Appendix I for locations of the numbered bay sites). 


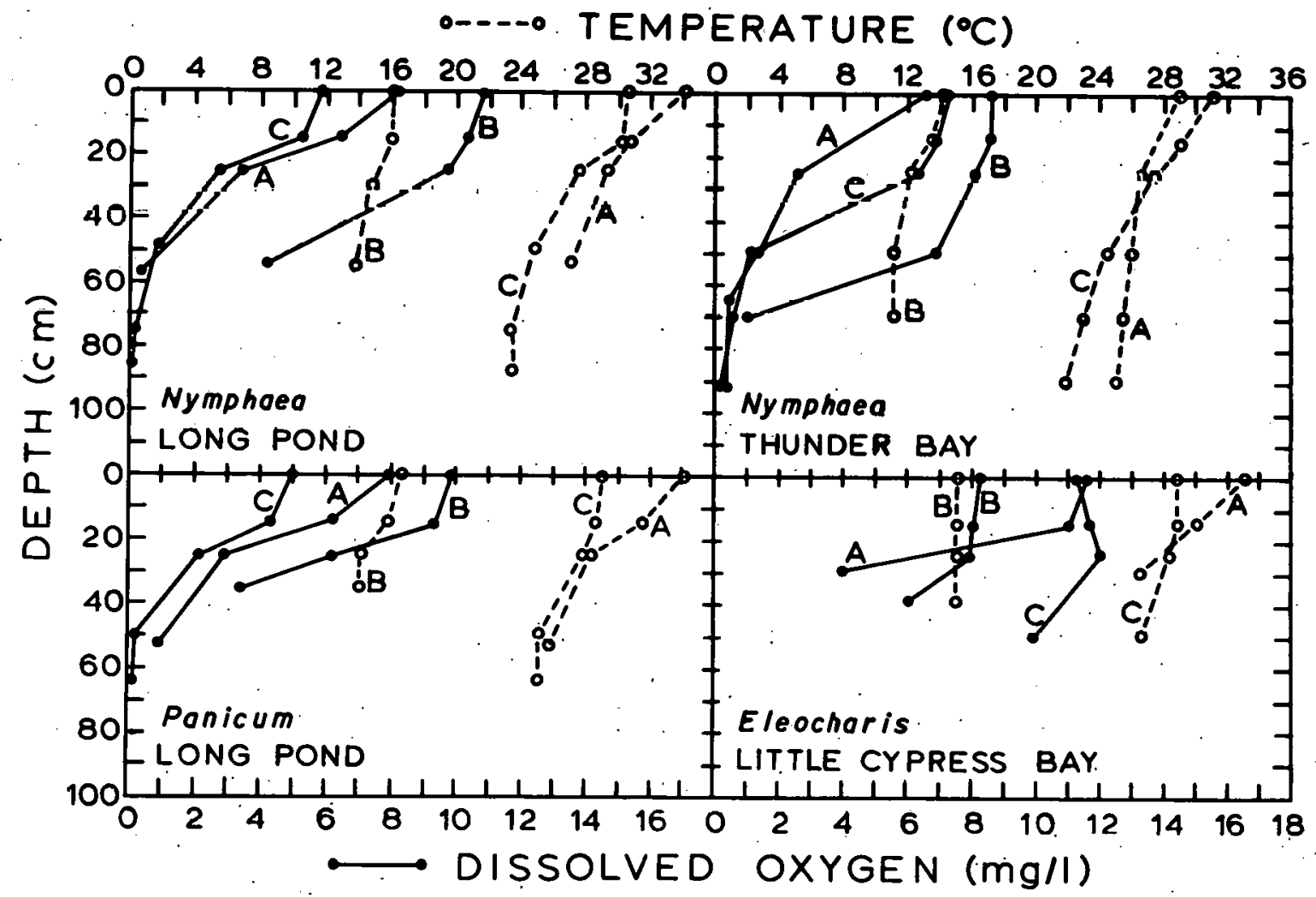

Figure 7. Vertical profiles of dissolved oxygen and temperature at four sampling stations in three of the Carolina bays used in the 1974-75 intersite comparisons (Schalles 1979): The data presented are typical of those-found in emergent (see Panicum and Eleocharis) and floating leaf (see Nymphaea) vegetation zones. Lowest data points in profiles represent depth at which bottom was encountered. All data were obtained in afternoon periods (A--September 1974, B--February 1975, C--June 1975). 
Sand, silt, and clay averaged $45.5 \%, 20.1 \%$, and $34.4 \%$, respectively. However, the proportions varied considerably, with percent sand values ranging from $27.0-62.2 \%$ in the six bays (Table 7). Although the two sites at the Barnwell Nuclear Fuel Plant experienced significant siltation and runoff from a construction area, their textures were near average. Bulk samples (upper $20 \mathrm{~cm}$ ) from the wetland interiors of eight other bays on the east side of the SRP and adjacent Barnwell County had the following sand, silt, and clay proportions $[\underline{n}=16$; $\overline{\mathbf{x}}$ (S.D.)]: $61.8 \%(16.9 \%), 23.6 \%(10.3 \%)$, and $14.6 \%$ $(9.1 \%)$. The reason for the higher sand and lower clay values in this second group of sites is unclear. However, average sand and clay percentages in this latter group of eight bays were similar to the averages reported for two Carolina bays with mineral soil in northeastern South Carolina (Jones 1981) and for 12 low elevation bays of Virginia's Eastern Shore (Bliley and Pettry 1979).
Loss on ignition (LOI) data were obtained (combustion at $550^{\circ} \mathrm{C}$ for 24 hours) for three depth strata in thirty-one soil cores from the wetland communities of fifteen sites surveyed for this report. LOI values were generally low at all depths (Figure 8). These low values confirm the relatively oxidized, mineral nature of surface soils in upper coastal plain bays as reported by Frey (1951) for higher elevation North Carolina sites. Frequency analyses revealed a bimodal distribution for organic content in the 0-7.5 $\mathrm{cm}$ layer and tighter clustering for the two deeper layers (Figure 8). Correlation coefficients $(r$ ) for the upper/middle, upper/lower, and middle/lower strata LOI pairings were $0.77,0.70$, and 0.83 , respectively. Many SRP bays have surface organic layers of less than $15 \mathrm{~cm}$. However, the maximum thickness of peat in site 142 exceeds $1 \mathrm{~m}$. Three peat samples from this bay had an average LOI of $87.3 \%$. The occurrence of significant peat in site 142 could reflect a more stable hydrology with almost

Table 6. Water chemistry of eight stations at Dry Bay (Site 31) measured with a Hydrolab on December 7, 1979.

\begin{tabular}{|c|c|c|c|c|c|c|}
\hline Station & Description & ${ }^{\circ} \mathrm{C}$ & $\mathrm{pH}$ & $\begin{array}{c}\text { Redox } \\
\left(E_{h}\right)\end{array}$ & $\begin{array}{c}\mathrm{O}_{2} \\
(\mathrm{mg} / \mathrm{l})\end{array}$ & $\begin{array}{c}\text { Cond. } \\
(\mu \mathrm{mhos} / \mathrm{cm})\end{array}$ \\
\hline 1 & near shore, open pool & 10.4 & 5.2 & +230 & 7.6 & 30 \\
\hline 2 & open pool & 10.4 & 5.2 & +242 & 7.1 & 27 \\
\hline 3 & $\begin{array}{l}\text { open pool surrounded } \\
\text { by water lillies }\end{array}$ & 10.2 & 5.4 & +251 & 5.6 & 25 \\
\hline 4 & $\begin{array}{l}\text { abundant macrophytes } \\
\text { and detritus }\end{array}$ & 10.2 & 5.4 & +242 & 3.8 & 24 \\
\hline 5 & $\begin{array}{l}\text { open pool near center, } \\
\text { abundant detritus }\end{array}$ & 9.6 & 5.4 & +258 & 3.3 & 25 \\
\hline 6 & open pool & 9.3 & 5.5 & +211 & 4.2 & 26 \\
\hline 7 & $\begin{array}{l}\text { shallow, abundant } \\
\text { filamentous algae }\end{array}$ & 10.9 & 5.9 & +206 & 11.0 & 24 \\
\hline 8 & $\begin{array}{l}\text { near shore, abundant } \\
\text { macrophytes }\end{array}$ & 10.9 & 5.5 & +249 & 6.1 & 23 \\
\hline
\end{tabular}


continual groundwater recharge that reduces exposure to the atmosphere and enhances peat development. This bay is located between the 130 and $140 \mathrm{ft}(42.7-45.9 \mathrm{~m})$ isocontours and is relatively close to Steel Creek and the Savannah River floodplain. However, other SRP bays with similar locations near streams or the floodplain lack significant peat buildup. Hodge (1985) found several Carolina bays at the SRP and adjacent
Barnwell and Aiken Counties with peat layers of 50 $100 \mathrm{~cm}$.

Soil $\mathrm{pH}$ values were determined for several sites using soil/distilled water slurries (1:1 volume ratio, soil samples were air dried). The $\mathrm{pH}[\overline{\mathrm{x}} /($ S.D., derived by taking averages of the hydrogen ion concentrations), $\underline{n}=10$ ] of $0-7.5,7.5-15$, and 15-22.5 cm strata in five sites in our 1979 survey averaged

Table 7. Soil data for six Carolina bays on the SRP and adjacent Barnwell Nuclear Fuel Plant (BNFP). Data are averages for six stations at each site. Standard deviations are shown in parentheses.

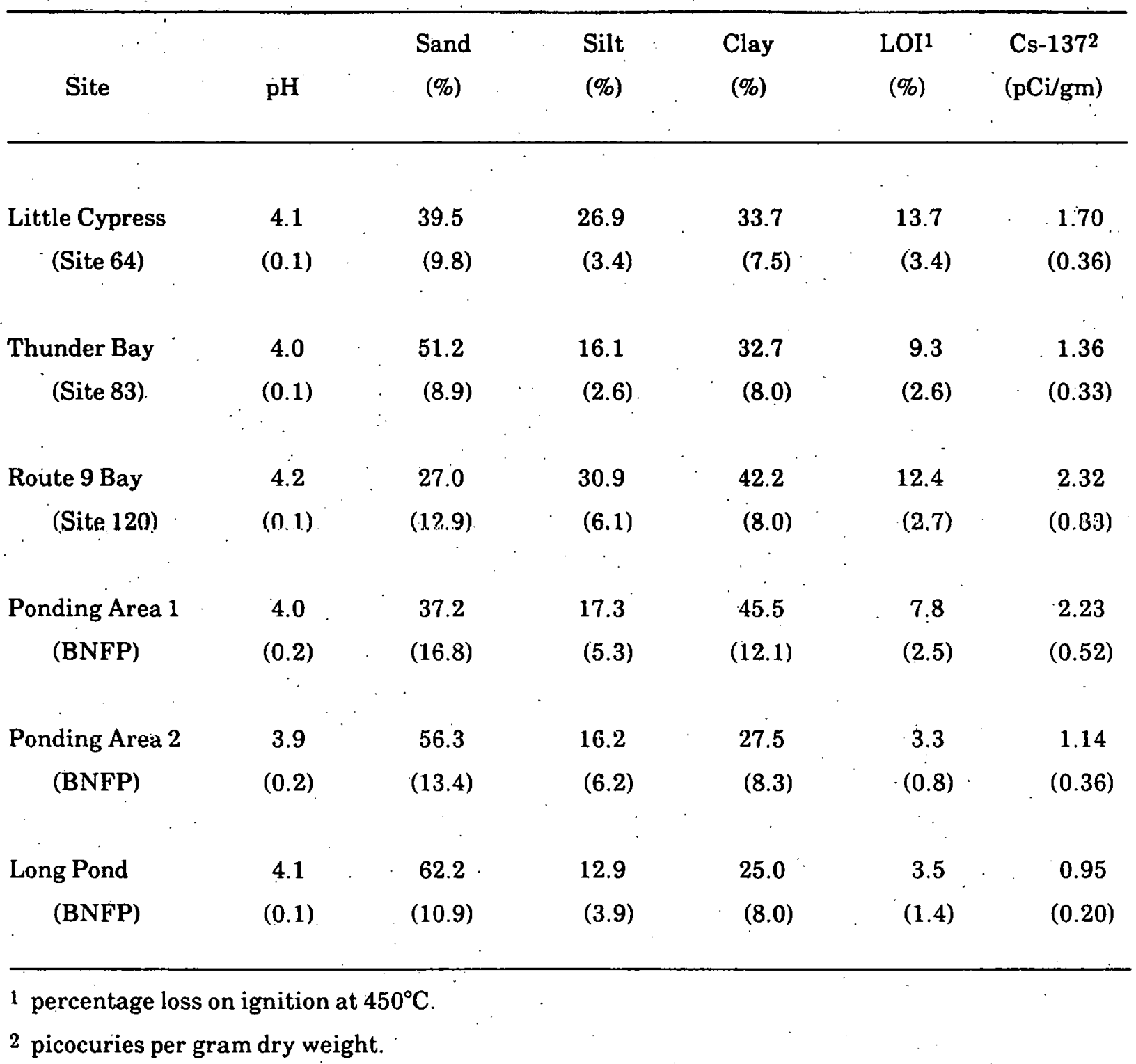




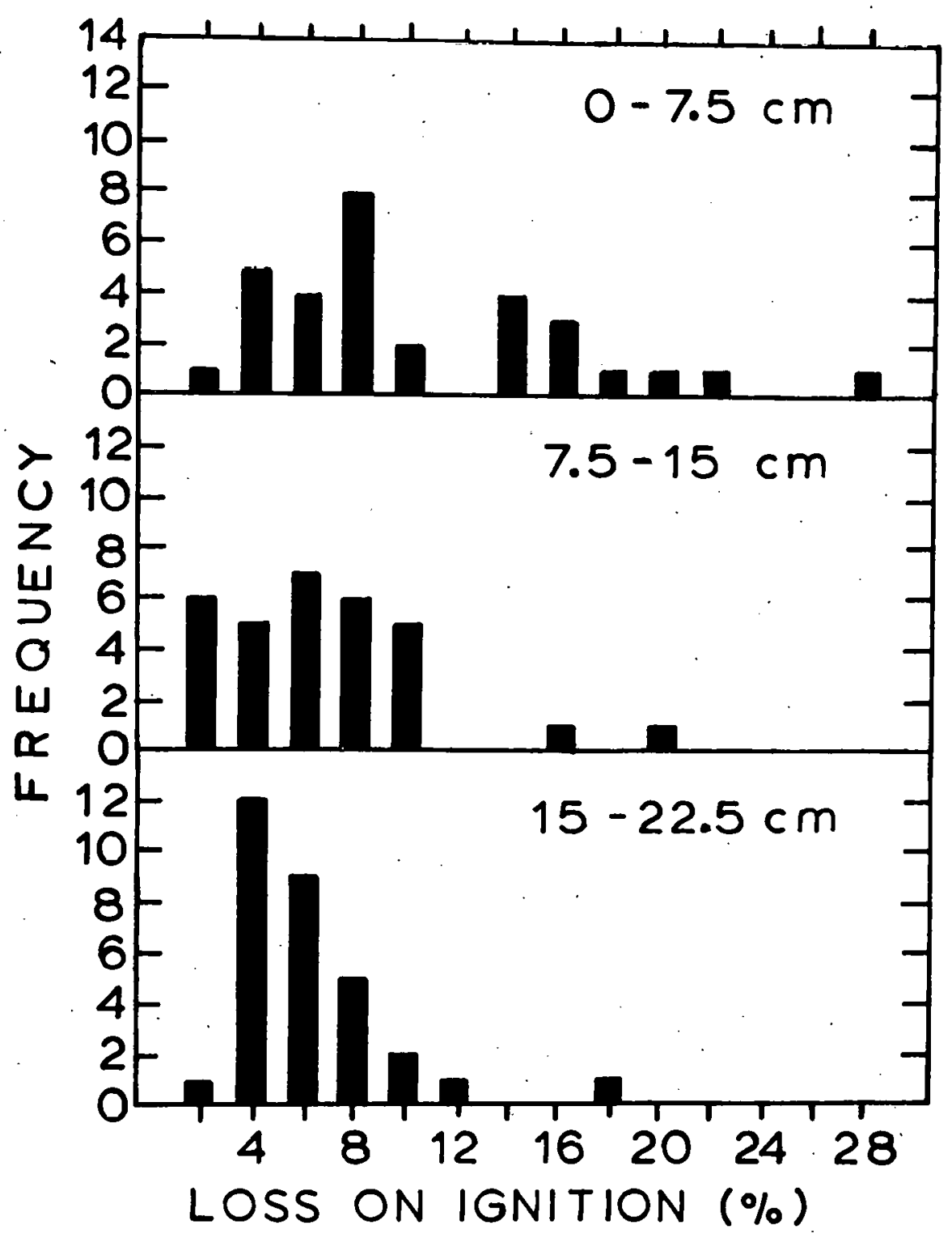

Figure 8. Frequency distribution of percentage loss on ignition (LOI) values for three depth strata in 31 soil/sediment cores from 15 Carolina bays at the SRP. 
$3.84(0.35), 3.83(0.41)$; and $3.81(0.47)$ : Soil $\mathrm{pH}$. values (upper $20 \mathrm{~cm}$ ) of the six bays in the 1973-74 comparative study ranged from 3.9-4.1 (Table 7). The acidic, reduced conditions of saturated bay soils must be a dominant chemical factor. However, no significant correlations were found between $\mathrm{pH}$ and soil texture, \% LOI, or soil Cs137 (Table 8).

Values of Cs 137 from global atmospheric fallout were determined for sampling station soils in the six sites used in the 1973-74 comparison (Table 7). Activity levels were measured in oven-dried soil samples placed in counting vials and analyzed for Cs 137 using a Nuclear-Chicago autogamma counting system with a $7.7 \mathrm{~cm} \mathrm{NaI(TI)} \mathrm{well-type} \mathrm{scintillation}$ crystal. Samples were run until 4000 counts were accumulated (20 cpm background) and counting rates were corrected for background, counting efficiency, sample geometry, and sample weight. A substantial range $(0.95-2.32 \mathrm{pCi} / \mathrm{g})$ was found in the site averages. As expected, $\mathrm{Cs}^{137}$ levels had positive correlations with percentages of clay and organic matter and a negative correlation with sand percentages (Table 8). Soil retention capacity, rather than differences in loading rates and hydrologic turnover, appears to be the dominant factor affecting intersite fallout cesium differences.

Hodge (1985) conducted soil ohemistry analyses for Carolina bays on or near the SRP. Data for seven variables from twenty-four locations in six bays are summarized in Tables 9 and 10 . The range of LOI values was similar to those reported above, whereas $\mathrm{pH}$ values were higher (Table 9). A remarkable consistency was found in the cation exchange capacity values of the six sites. Low levels of extractable cations and phosphorus were found. However, Sister Lake (near the SRP) had noticeably higher extractable $\mathrm{P}, \mathrm{Ca}$, and $\mathrm{Mg}$ than the other sites (Table 9). Extractable nitrate was consistently nondetectable in Hodge's samples. Phosphorus har very strong positive correlations with calcium and LOI (Table 10). Other significant positive correlations included $\mathrm{Ca} / \mathrm{LOI}, \mathrm{CEC} / \mathrm{pH}, \mathrm{Ca} / \mathrm{Mg}$, and $\mathrm{CEC} / \mathrm{K}$. Relatively strong negative correlations were found for $\mathrm{pH} / \mathrm{P}$ and $\mathrm{pH} / \mathrm{LOI}$ (Table 10). The low levels of exchangeable soil nutrients are consistent with the dilute, nutrient poor water of Carolina bay wetlands. Woodwell (1958) found that growth of pine seedlings in bay soils was strongly limited by

Table 8. Pearson product-moment correlation coefficient ( $r$ ) matrix for parameters of surface (upper $20 \mathrm{~cm}$ ) soils for six stations in each of six Carolina bays at the SRP and adjacent Barnwell Nuclear Füel Plant.

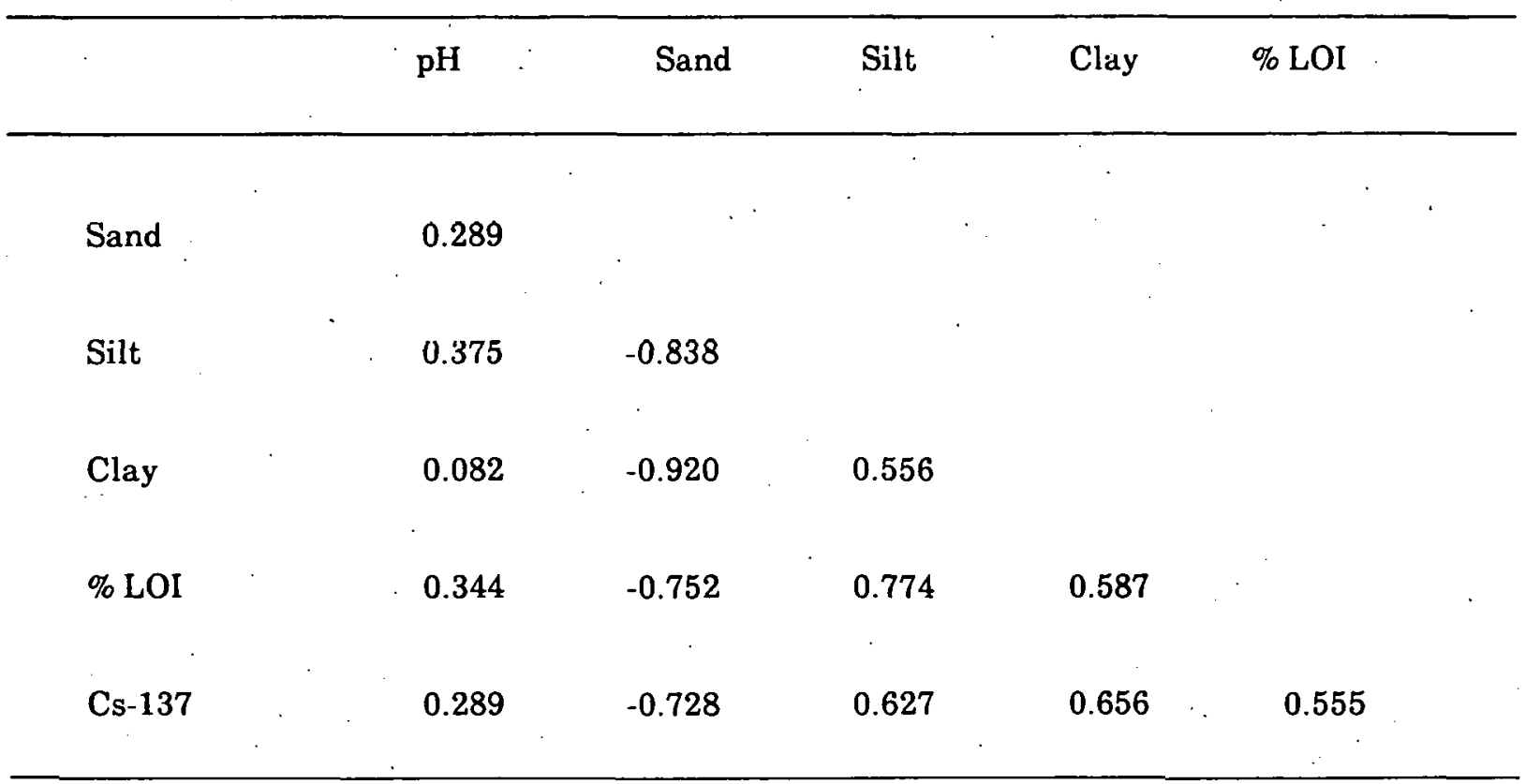


both $P$ and $N$. The comparatively low organic matter, which may include a significant fraction of inert charcoal fragments, and the low to moderate clay levels presumably limit nutrient binding and exchange capacities of bay soils. Nutrients such as $\mathrm{N}$ and $\mathrm{P}$ normally are found in less available organic forms in such soils (Barnes 1981).

\section{VEGETATION}

Several wetland community types typical of undrained coastal plain sites are found within SRP bay depressions. A list of vascular plants for eight bays studied by Hodge (1985) on and adjacent to the SRP is given in Appendix III. Topographical relief and hydrology are the principal determinants of vegetation composition in the bays, although edaphic conditions play a role. The duration and magnitude of inundation creates a range of conditions favoring different vegetation associations.

A xeric to hydric gradient occurs from the peripheral sand rim to the center of bay depressions. Kelley and Batson (1955) described several concentric vegetational zones in Craig's Pond (Site 77). The outermost zone lies along the sandy rim of the bay and is dominated by trees such as loblolly (Pinus taeda) and longleaf pines (P. palustris), black gum (Nyssa syluatica), blackjack oak (Quercus marilandica), turkey oak (Q. laevis), and sweet gum (Liquidambar styraciflua). Several shrubs, such as sumac (Rhus copallina), gallberry (Ilex glabra and I. coriacea), and red bay (Persea borbonia) also occur

Table 9. Summary of soil chemistry analyses for six Carolina bays on the SRP and Barnwell County, SC (from Hodge 1985). Elemental analyses are given as parts per million of extractable ions. Extractable nitrate (values not given) was less than $1 \mathrm{ppm}$ in all samples.

\begin{tabular}{lcccccccc}
\hline \multicolumn{1}{c}{ Site } & (n) & $\mathrm{P}$ & $\mathrm{K}$ & $\mathrm{Ca}$ & $\mathrm{Mg}$ & $\mathrm{CEC} 1$ & \% LOI2 & $\mathrm{pH}$ \\
\hline $\begin{array}{l}\text { Woodward Bay } \\
\text { (Site 67) }\end{array}$ & 3 & 3 & 24 & 68 & 7 & 28.6 & 9.2 & 4.6 \\
$\begin{array}{l}\text { Craigs Pond } \\
\text { (Site 77) }\end{array}$ & 4 & 2 & 8 & 49 & 4 & 28.3 & 9.6 & 4.5 \\
$\begin{array}{l}\text { Sarracenia Bay } \\
\text { (Site 78) }\end{array}$ & 4 & 7 & 14 & 67 & 9 & 28.8 & 6.4 & 4.6 \\
$\begin{array}{l}\text { Ellenton Bay } \\
\text { (Site 176) }\end{array}$ & 4 & 4 & 15 & 110 & 8 & 29.7 & 3.9 & 5.0 \\
$\begin{array}{l}\text { Sister Lake } \\
\text { (Barnwell Co.) }\end{array}$ & 6 & 15 & 19 & 230 & 16 & 29.2 & 8.5 & 4.6 \\
$\begin{array}{l}\text { Youngblood Bay } \\
\text { (Barnwell Co.) }\end{array}$ & 3 & 1 & 20 & 68 & 6 & 28.7 & 11.3 & 4.6 \\
\hline
\end{tabular}

1 Cation exchange capacity (meq/100 g dry weight).

2 Percentage loss on ignition at $450^{\circ} \mathrm{C}$. 
here. Inside this zone of woody species are several bands of herbaceous vegetation, each of which is dominated by grass species. The first is characterized by broomsedge (Andropogon virginicus), but also contains numerous herbs including pitcher plants (Sarracenia spp.). Inside this zone is a band of vegetation dominated by threeawn grass (Aristida affinis) and in deeper water areas, surrounding the central pool of water, species of maidencane (Panicum spp.) are abundant. The pond in the middle of the bay contains typical floating-leaved aquatic plants such as the water lilies Nymphaea odorata and Nymphoides aquaticum. In a subsequent floristic study of Craig's Pond, Hodge (1985) found similar patterns, with the exception of the area between the Andropogon and Panicum zones (Figure 9).

Seventeen natural herbaceous community types were found in the eight Carolina bays studied by Hodge (1985). As many as six types were found in one bay (Craig's Pond). For Craig's Pond and Ellenton Bay (Site 176), the composition and distribution of herbaceous species in community types along the hydrologic gradient from the rim to the hydric center are illustrated in Figures 9 and 10.
Ordination results of vegetation cover data for samples from Craig's Pond support a preliminary designation of six community types (Hodge 1985; Figure 11). There is a general trend from hydric to mesic conditions (left to right) along the detrended correspondence analysis (DCA) Axis 1. The distribution or arrangement of community type samples along this axis reflects a gradient from permanently inundated wetland to seasonally wet/dry wetland. The arrangement of samples along Axis 1 is the same as the natural arrangement of community types in Craig's Pond. The distribution of samples along DCA Axis 2 appears to follow the gradient of peat observed in Craig's Pond soils. The Nymphaea odorata-Brasenia schreheri community type occurs in the deepest water and on $0.2-0.5 \mathrm{~m}$ thick peat deposits, while Panicum hemitomonPontederia cordata occur on peat deposits over 1 in thick.

Ordinations by Hodge (1985) of vegetation samples from Ellenton Bay (Figure 12) do not reveal a major gradient. Ellenton Bay was disturbed before the early 1950s when the Atomic Energy Commission acquired the area. Aerial photographs of Ellenton Bay taken in 1943 show that part of the

Table 10. Pearson product-moment correlation coefficient matrix for soil chemistry parameters in six Carolina bays on the SRP and in Barnwell County, SC $(\underline{n}=24$, data from Hodge 1985).

\begin{tabular}{|c|c|c|c|c|c|c|}
\hline . & $\mathrm{pH}$ & $\mathbf{P}$ & $\mathrm{K}$ & $\mathrm{Ca}$ & $\mathrm{Mg}$ & CEC \\
\hline $\mathbf{P}$ & -0.537 & & & & & \\
\hline $\mathbf{K}$ & 0.327 & -0.155 & & & & . \\
\hline $\mathrm{Ca}$ & -0.401 & 0.940 & 0.077 & & & \\
\hline $\mathrm{Mg}$ & -0.179 & 0.691 & 0.471 & 0.858 & & \\
\hline CEC : & 0.769 & 0.022 & 0.522 . & 0.227 & 0.435 & \\
\hline$\% \mathrm{LOI}^{\prime}$ & -0.564 & 0.963 & $=0.049$ & 0.973 & 0.760 & 0.022 \\
\hline
\end{tabular}




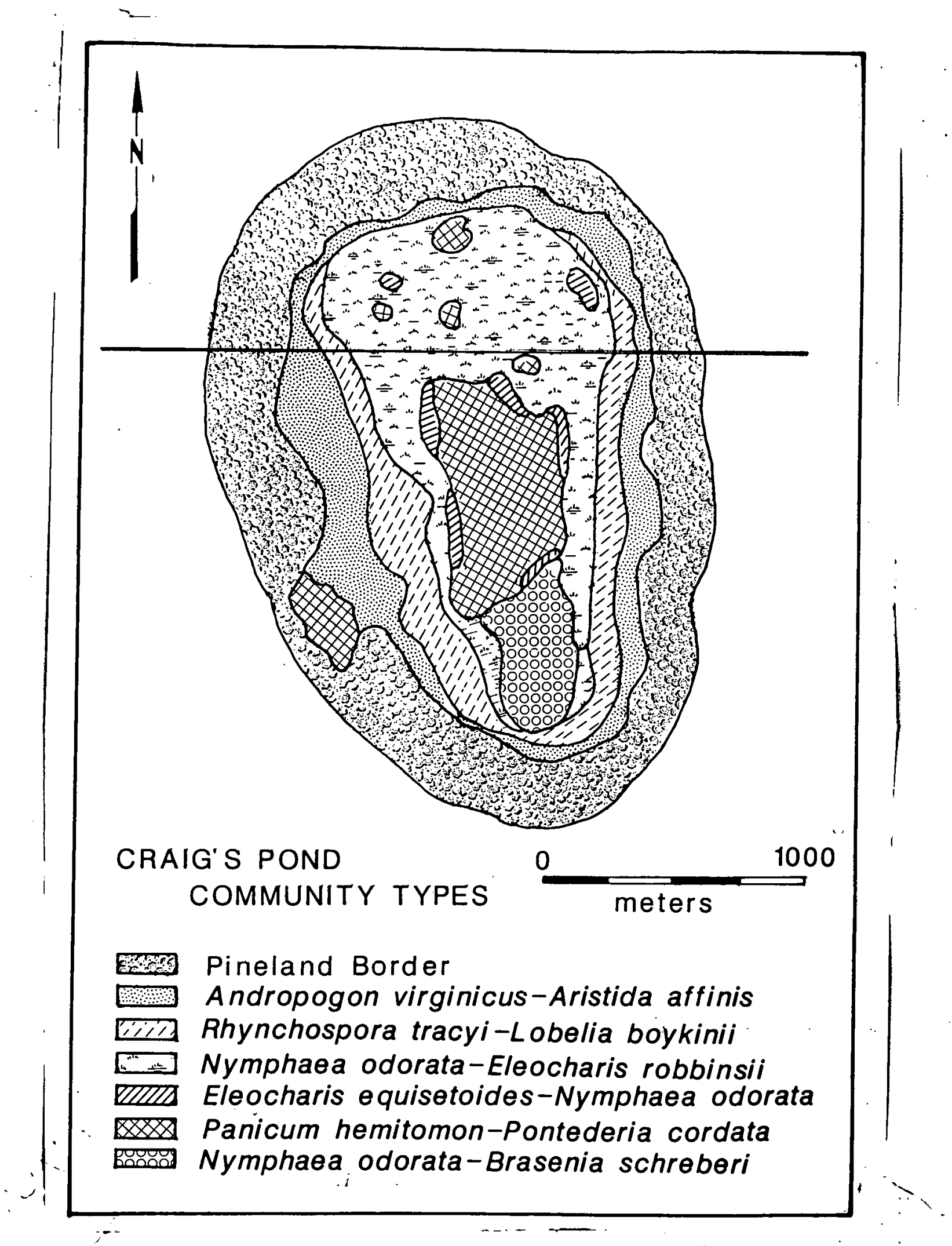

Figure 9. Community types at Craig's Pond (Site 77; Hodge 1985). 


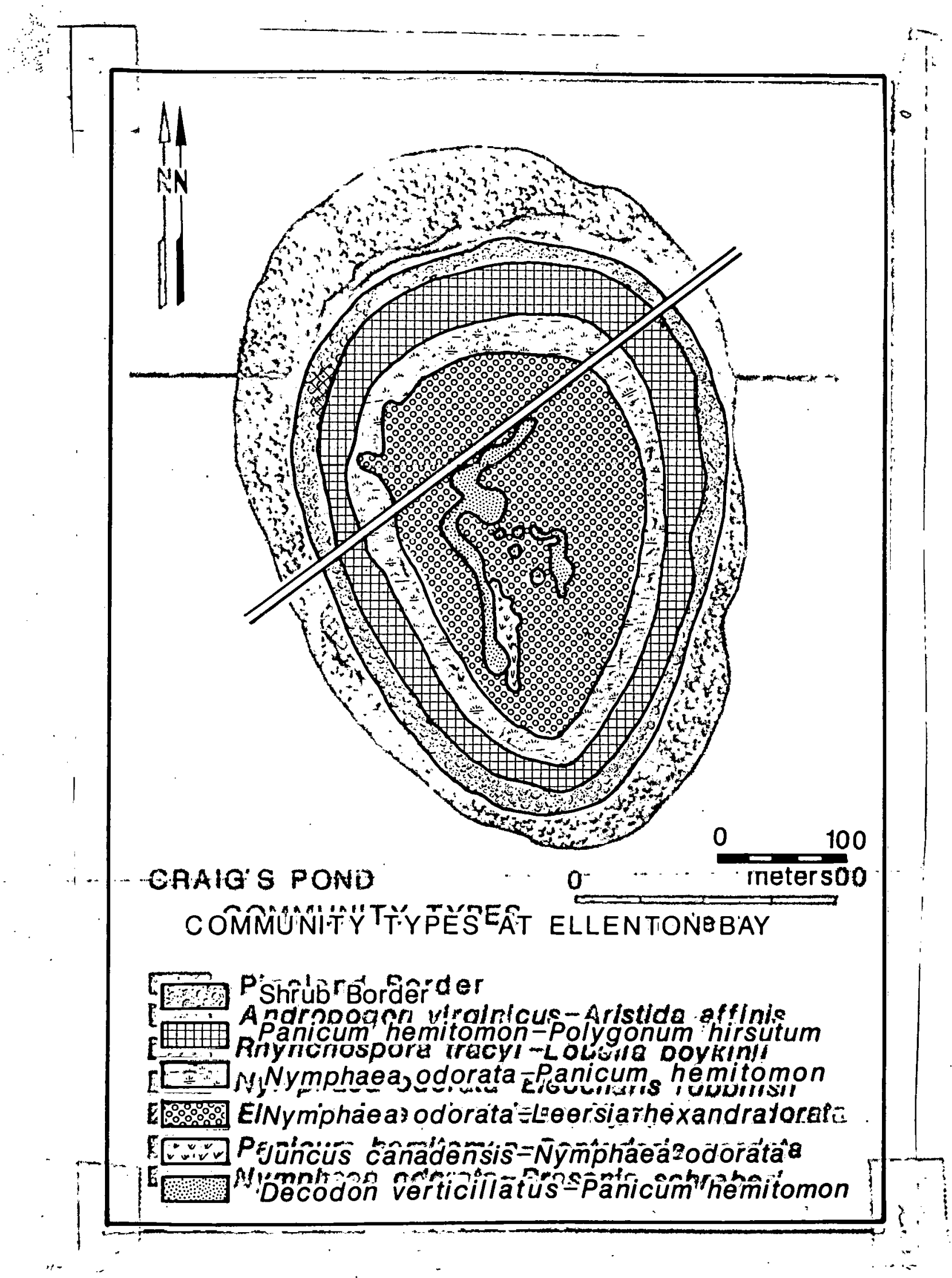

Figure 10. Community types at Ellenton Bay (Site 176; Hodge 1985). 
Floristics Ordination (DCA) of Cover Data for Community Types at Craig's Pond

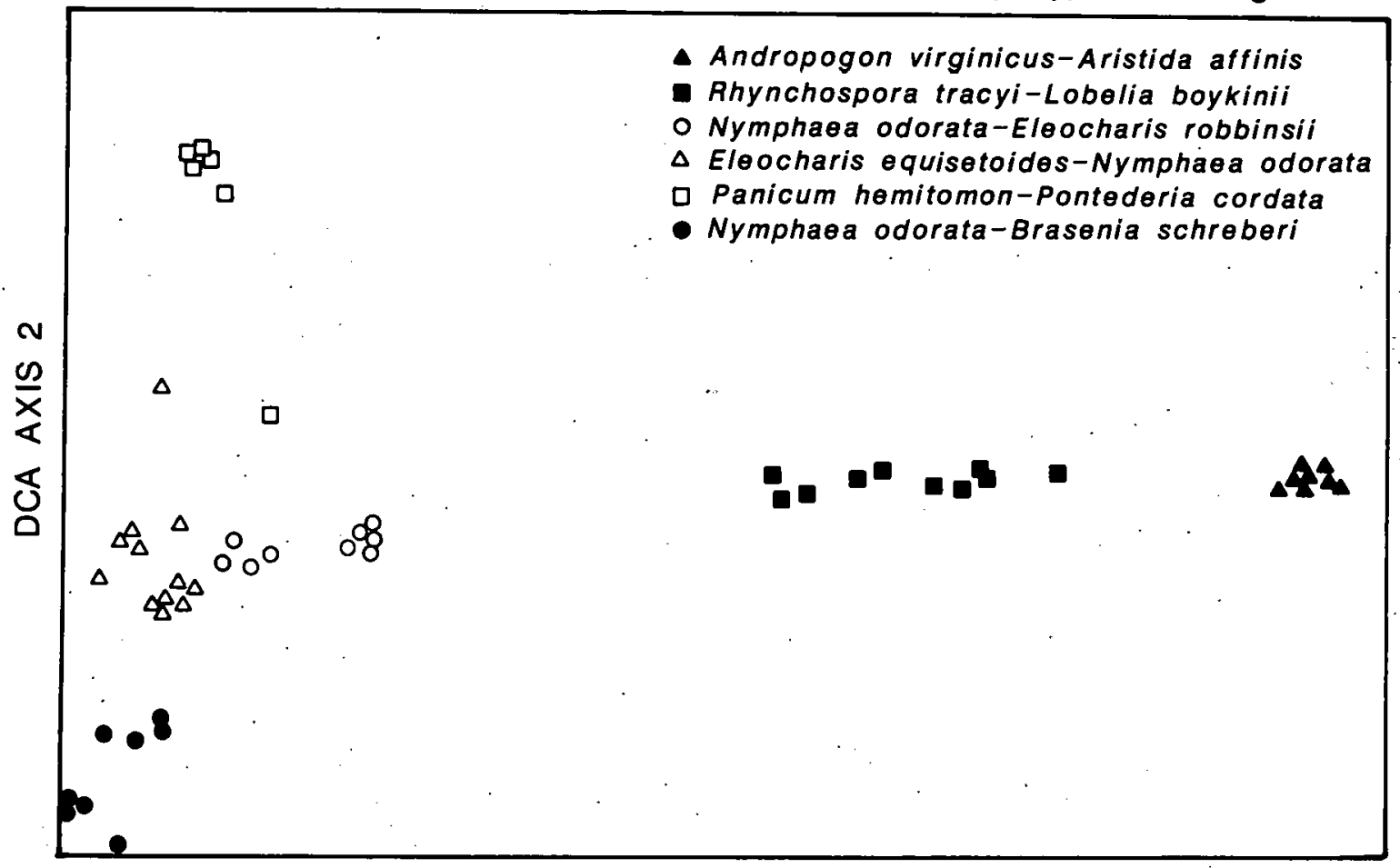

DCA AXIS 1

Figure 11. Detrended correspondence analysis ordination of vegetation cover data from Craig's Pond (Site 77; Hodge 1985). 
Floristics Ordination (DCA) of Cover Data for Community Types at Ellenton Bay

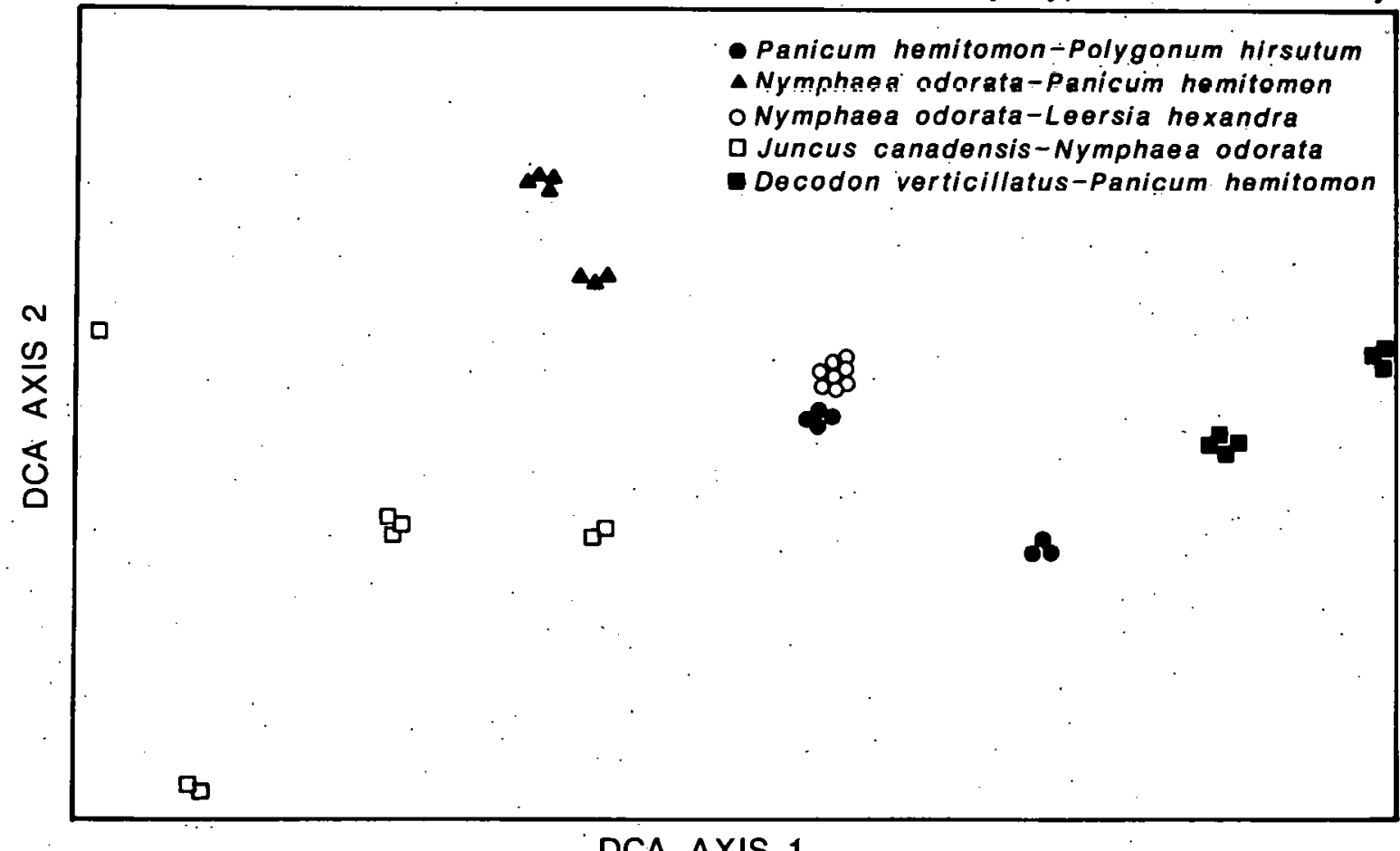

DCA AXIS 1

Figure 12. Detrended correspondence analysis ordination of vegetation cover data from Ellenton Bay (Site 176; Hodge 1985). 
bay and surrounding area was intensively cultivated and pastured prior to acquisition. This previous cultivation may explain the almost perfectly concentric pattern of low diversity community types found in Ellenton Bay today (Figure 10).

Field observations and the results of Hodge's study (1985) suggest that short-term succession from herbaceous to woody dominated communities in bays of the Upper Coastal Plain occurs when water levels are low. After a bay has been ditched and drained, Cephalanthus occidentalis, Diospyros virginiana, or Liquidambar styraciflua commonly germinate on the exposed soil. A woody-dominated community soon becomes established. In undisturbed bays, organic material accumulates faster in the semipermanently to permanently inundated areas where conditions are at or approach anoxia throughout the year. In these deeper areas of the bays, peat may accumulate until it is exposed during periods of low water levels. During these periods, seeds of woody species may become established and initiate the development of a woodydominated community. Thus, long-term succession may proceed by the process of paludification.

Another interpretation of long-term community succession is based on the abundant charcoal fragments in bay soils and the rates of inorganic filling which appear to be extremely low in undisturbed sites. A cyclical succession pattern may have maintained relatively stable community structures throughout the Holocene. Under this scenario, periodic drying and fires, coupled with negligible inorganic filling, have prevented the classic linear succession pattern of basin filling. Present vegetation patterns may simply reflect the current moisture gradients and recent fire histories within these sites. It seems probable that short-term population distribution patterns shift with prevailing moisture conditions. Short-term cycles may, in turn, be superimposed on a relatively longer-term geological trend (perhaps thousands of years) of a reduction in average water level and an increase in hydroperiod amplitude as a result of eroding regional streams, lowering of water tables by valley excision, and a very gradual inorganic filling of the depressions from aeolian transport.

Few studies have measured the primary productivity of these diverse wetlands. Schalles and Shure (1989) described the vegetation of Thunder Bay (Site 83) as dominated by a shallow zone of maidencane (Panicum hemitomon) and cutgrass (Leersia hexandra), and a deeper central area of water lily (Nymphaea odorata) and water shield (Brasenia schreberi). Standing root crop averaged $780 \mathrm{~g} \mathrm{dry} \mathrm{wt} / \mathrm{m}^{2}$ in the aquatic zone. Root/shoot ratios were high and averaged about 8 . Total net primary production of macrophytes (harvest method) averaged about $260 \mathrm{~g}$ dry $\mathrm{wt} / \mathrm{m}^{2} / \mathrm{yr}$. Algal composition in Thunder Bay was dominated by desmids, diatoms, and filamentous chlorophytes. Algal chlorophyll a averaged $25 \mathrm{mg} / \mathrm{m}^{2}$. Significant levels of photosynthetic bacteria pigments were found in samples from Thunder Bay and several other SRP bay sites. Bacteriochlorophyll a averaged $17 \mathrm{mg} / \mathrm{m}^{2}$ in Thunder Bay (Schalles and Shure 1989).

The distribution and temporal dynamics of detritus in the bays with mineral soil is of particular interest. Detritus rarely achieves steady state levels because of water level dynamics. Decomposition of saturated detritus may proceed relatively slowly in these acidic, reduced environments until drying occurs. Kormondy (1968) studied decomposition rates in the Nymphaea odorata and Brasenia schreberi zones of Ellenton Bay. He believed that the decomposition rates in the pond, as measured by Nymphaea and Brasenia leaf decomposition and cellulose strip disappearance, were insufficient to accommodate the annual detritus input. Detritus was measured in situ in Thunder Bay (Schalles 1979). Coarse particulates $(\geq 6 \mathrm{~mm})$ and fine particulates $(<6 \mathrm{~mm})$ in the detrital mat averaged 290 and $790 \mathrm{~g} \mathrm{dry} \mathrm{wt} / \mathrm{m}^{2}$, respectively. Fine particulates had a rather even distribution whereas levels of coarse particulates were notably higher in emergent vegetation zones.

\section{INVERTEBRATE FAUNA}

Invertebrates have been described from only a few Carolina bays of the SRP. Cross (1955) surveyed odonate distributions in Carolina bays and other aquatic habitats of the SRP. Invertebrates were intensively surveyed in 1979 at Rainbow Bay (Site 189) and Sun Bay (Site 45), with detailed listings of taxa and their relative abundances provided in tabular form (Savannah River Ecology Laboratory 1980). Intensive work at Sun Bay disclosed a diverse insect assemblage with 119 families from fourteen orders identified. Artificial substrate collectors were placed in several aquatic 
microhabitats in and around the two bays. Dipterans were the most abundant taxa at both Sun and Rainbow Bays. Oligochaetes and isopods were relatively common in the Rainbow Bay collectors, but were not collected in Sun Bay (Table 11).

Macroinvertebrates were quantified from 1975-77 at Thunder Bay (Site 83) using a cylinder enclosure technique (Schalles and Shure 1989). Total macroinvertebrate biomass was low with an annual average of about $800 \mathrm{mg}$ dry $\mathrm{wt} / \mathrm{m}^{2}$. Four insect orders dominated the invertebrates. Odonates, dipterans, hemipterans, and coleopterans averaged $396,210,87$, and $83 \mathrm{mg} / \mathrm{m}^{2}$, respectively. Macroinvertebrates in Thunder Bay were similar in composition, but contributed only about $20 \%$ of the benthic biomass measured by Benke (1976) in an abandoned farm pond on the SRP. . The dystrophic bog chemistry and periodic drying apparently prevent or severely restrict the occurrence of several freshwater invertebrate groups in the Thunder Bay wetland community. Ephemeropterans, megalopterans, and trichopterans were infrequent and plecopterans, amphipods, isopods, decapod crustaceans, gastropods (except the limpet Ferrisia), bivalves, and oligochaetes were absent during this study. The very low calcium levels in undisturbed upper coastal plain bays may be the primary limiting factor for molluscs, decapods and other malacostracans, and perhaps annelids. Snails were frequently observed in two nearby Carolina bays at the Barnwell County Industrial Park. The bays had received runoff and sediments from a construction area and had significantly higher calcium levels (averages of 9.5 and $14 \mathrm{mg} / \mathrm{l}$ for the two sites).

Table 11. Density of certain insect orders, oligochaetes, and isopods (number of individuals/20 $\mathrm{cm}^{2}$ ) determined by artificial substrate sampling at Rainbow (Site 189) and Sun (Site 45) Bays. Data from Savannah River Ecology Laboratory (1980).

TAXA

Microhabitat Ephemeroptera Coleoptera Diptera Hemiptera Odonata Tricoptera Oligochaeta Isopoda

Rainbow Bay

Deepopen water.

2.5

0

44.5

0.5

3

0 .

16.5

10.5

Shallow water in

button bush

4.5

1.3

9.6

3.3

1.6

0

5

15.3

Sun Bay

Open disturbed
pond

Open weed-filled pond
0

1.5

30.5

1

59

1

41

38.5

0

0.5

1

101

101

0

5

(1)

0

0

0.5

o

0

0

Pond i
bush

Drainage ditch, flowing

$\begin{array}{llll}0 & 0 & 0 & 0\end{array}$


The zooplankton of Carolina bays on the SRP are diverse, abundant, and at least moderately productive (Taylor et al. 1989, Mahoney, Mort, and Taylor, unpublished). Calanoid and cyclopoid copepods, cladocerans, and rotifers are ubiquitous. Anostracans and conchostracans are sporadically distributed, but may be very abundant where they occur. The median biomass of zooplankton in Rainbow Bay was $100 \mathrm{mg} \mathrm{dry} \mathrm{wt} / \mathrm{m}^{2}$ in 1984 and production was $6.2 \mathrm{~g} \mathrm{dry} \mathrm{wt} / \mathrm{m}^{2}$ or $62 \mathrm{~kg}$ for the entire bay. The community in Rainbow Bay showed marked changes in species composition during the wet season (Figure 13). In such bays, which function as temporary ponds, all of the zooplankton have resting stages that lie dormant in the sediments during the dry season. Varied times of emergence from these resting stages contribute to the succession of species in Rainbow Bay. Zooplankton comprise an important part of the diets of larval salamanders (Taylor et al. 1988). Insect larvae may also prey heavily on the zooplankton.

\section{VERTEBRATE FAUNA}

Vertebrates are conspicuous and relatively abundant members of the Carolina bay fauna. Perhaps because of the water level ossillations and dry periods, no vertebrates found in SRP bays are considered strictly endemic to such habitats of the Sandhills coastal plain region. All aquatic and semi-aquatic vertebrates, except fish, apparently use migration or aestivation strategies during dry periods. For example, sirens (Siren intermedia and Siren lacertina) form cocoons and aestivate during dry-outs (Conant 1975). The mole salamander (Ambystoma talpoideum) is commonly terrestrial as an adult but is paedogenic in situations where water is usually permanent. It may have evolved this pattern of metamorphosis in response to unpredictable water levels that may result in potentially ephemeral aquatic habitats becoming permanent ponds with no fish predators (Patterson 1978, Semlitsch 1985).

Although large Carolina bay lakes in North Carolina have resident fish populations composed of several species (Frey 1951, Bailey and Frey 1958), it is likely that most bays do not have permanent fish inhabitants because of periodic drying. Fishes have been observed in several Carolina bays on the SRP (Bennett and McFarlane 1983). The following fish were observed in four Carolina bays on the SRP during 1978-1983: redfin pickerel (Esox americanus), mud sunfish (Acantharchus pomotis), sunfish (Lepomis spp.), lake chubsucker (Erimyzon sucetta), and mosquitofish (Gambusia affinis; Thorp and Caldwell, personal observation). Fewer than $10 \%$ of the Carolina bays on the SRP are known to have permanent fish populations, although overwash from neighboring swamps or streams may reestablish the ichthyofauna of formerly dry basins.

Although fishes are not a dominant feature in most bays, other vertebrates are diverse and their productivity may be high. Several species of reptiles and amphibians are associated with Carolina bays on the SRP (Gibbons and Patterson 1978, Gibbons and Semlitsch 1990). Gibbons (1970) noted over thirty species of amphibians and reptiles in and around Ellenton Bay (Site 176). The use of bays by vertebrates is sometimes astonishing, as revealed by the high number of semi-aquatic animals migrating to and from the water (Table 12). Rainbow Bay (Site 189). which has an aquatic perimeter of less than $450 \mathrm{~m}$ (1476 ft), had approximately 10,000 individuals of the southern leopard frog (Rana utricularia) moving in or out in one year (Pechmann, personal observation). This is an average of one frog for every $2 \mathrm{~cm}$ of pond margin. A similar calculation for Ellenton Bay, which is much larger, indicates that one adult mole salamander (Ambystoma talpoideum) enters to breed each winter per $20 \mathrm{~cm}$ of perimeter (Patterson 1978) and as many as 11,000 recently metamorphosed individuals may exit during one week (Semlitsch, personal observation). These 11,000 salamanders are equivalent to one per $11 \mathrm{~cm}$ of perimeter and contribute a total biomass of $70 \mathrm{~kg}$. Schalles and Shure (1989) obtained in situ estimates of salamander density and biomass in the aquatic area of Thunder Bay (Site 83). No fish were present in the community. Over an annual cycle in a 1 ha sampling grid Siren intermedia, Notophthalmus viridescens, and Ambystoma talpoideum populations averaged $0.15,1.18$ and 1.46 individuals $/ \mathrm{m}^{2}$ and $8.03,3.12$, and $1.23 \mathrm{~kg} \mathrm{dry} \mathrm{wt/ha,}$ respectively. During the same period, anuran larvae (primarily Ranidae) averaged $1.03 \mathrm{~kg}$ dry wt/ha.

The abundance of amphibians in Carolina bays altered by agricultural, forest management, or construction activities (e.g., Sun Bay, Site 45, Table 12; Lost Lake, Site 28; Bennett et al. 1979), may be higher than expected. In 1979, more than 500 ornate chorus frogs (Pseudacris ornata), 5,000 


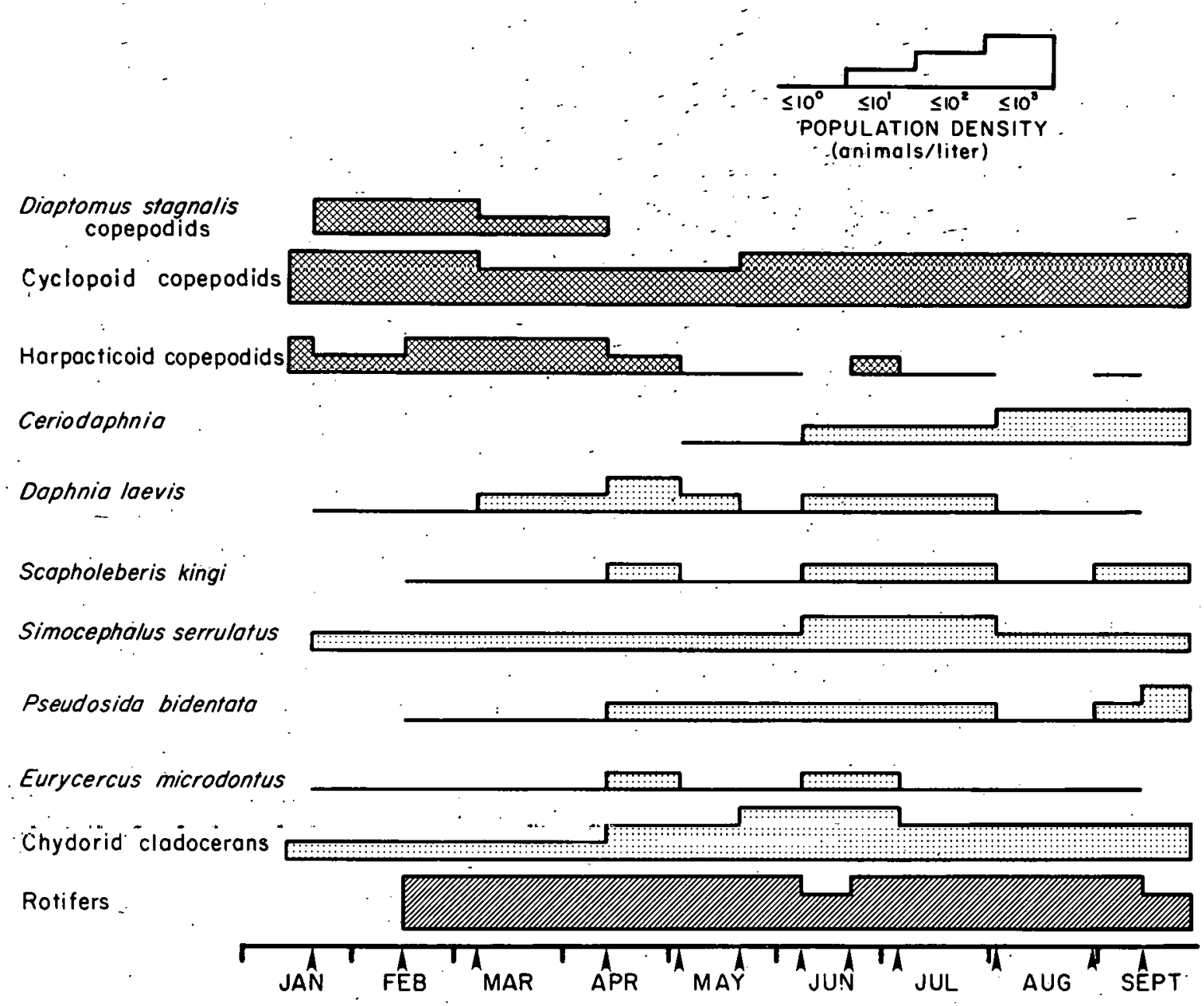

Figure 13. Changes in zooplankton species composition from January to September 1984 at Rainbow Bay, Site 189 (from Taylor, unpublished data). 


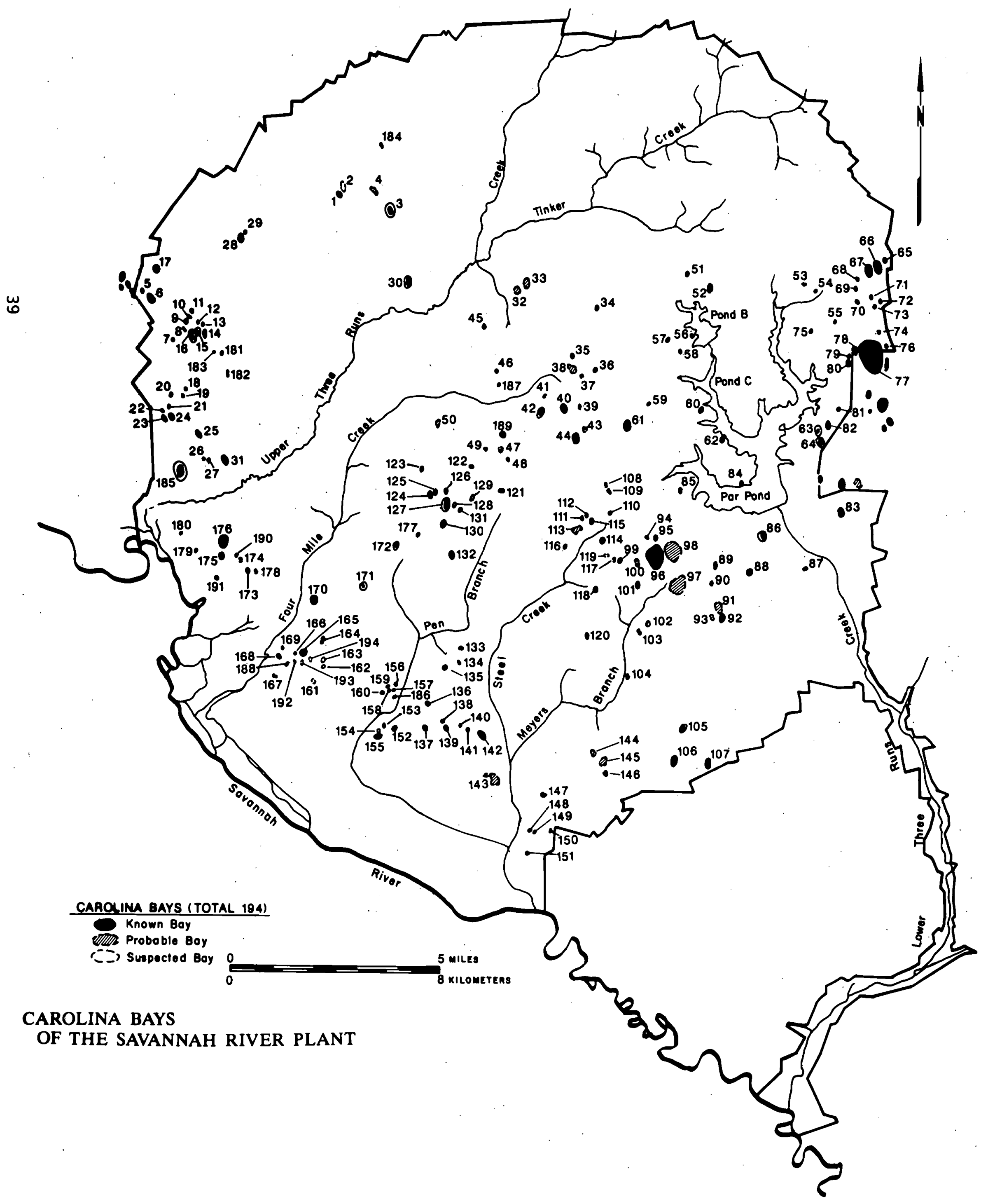

Figure 14. Known and suspected Carolina bays of the SRP, South Carolina. Numbers correspond to bay identities in Appendix I. 
Table 12. Utilization of Carolina bay habitats by small vertebrates. Numbers indicate selected vertebrate species captured (original and recaptured) in drift fences with pitfalls at Rainbow Bay and Sun Bay, SRP, SC; for one year, March 1979-March 1980 (adapted from Gibbons and Semlitsch 1982).

\begin{tabular}{|c|c|c|c|c|c|c|c|c|c|}
\hline \multirow{3}{*}{ Species } & \multicolumn{5}{|c|}{ Rainbow Bay } & \multicolumn{4}{|c|}{ Sun Bay } \\
\hline & & \multicolumn{2}{|c|}{ Entering } & \multicolumn{2}{|c|}{ Exiting } & \multicolumn{2}{|c|}{ Entering } & \multicolumn{2}{|c|}{ Exiting } \\
\hline & & Adult & Juv. & Adult & Juv. & Adult. & Juv. & Adult & Juv, \\
\hline \multicolumn{10}{|l|}{ Class Amphibia } \\
\hline \multicolumn{10}{|l|}{ Order Caudata } \\
\hline Ambystoma talpoideum & . & 1,750 & 154 & 499 & $.3,856$ & 6,028 & 0 & 938 & 0 \\
\hline Ambystoma tigrinum & & 129 & 46 & 42 & 992 & 57 & 1 & 4 & 1 \\
\hline Notophthalmus viridescens & & 1,625 & 968 & 609 & 15,013 & 3,452 & 5 & 2,100 & 23 \\
\hline Total of all salamanders & & & & & & & & & \\
\hline (9 species) & & 3,953 & 1,201 & 1,212 & 19,874 & 9,595 & 6 & 3,087 & 24 \\
\hline \multicolumn{10}{|l|}{ Order Anura } \\
\hline Scaphiopus holbrooki & & 69 & 33 & 39 & 34 & 1,803 & 134 & 483 & 58 \\
\hline Bufo terrestris & & 424 & 644 & 79 & 689 & 580 & 375 & 98 & 622 \\
\hline Hyla crucifer & & 346 & 212 & 205 & 1,329 & 594 & 12 & 239 & 50 \\
\hline Pseudacris ornata & & 235 & 28 & 89 & 1,158 & 392 & 9 & 79 & 18 \\
\hline Gastrophryne carolinensis & $\therefore$ & 1,122 & 18 & 418 & 15 & $88 ?$ & 1 & 420 & 0 \\
\hline Ranaclamitans & 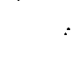 & 27. & 30 & 19 & 1,136 & 27 & 35 & 1 & 7 \\
\hline Rana utricularia & & 699 & 2,024 & 610 & 52,287 & 154 & 29 & 24 & $\cdot 7$ \\
\hline Total of all frogs & & & & & & & & & \\
\hline (16 species) & & 3,197 & 3,053 & 1,569 & 57,106 & 4,486 & 680 & 1,355 & 767 \\
\hline
\end{tabular}




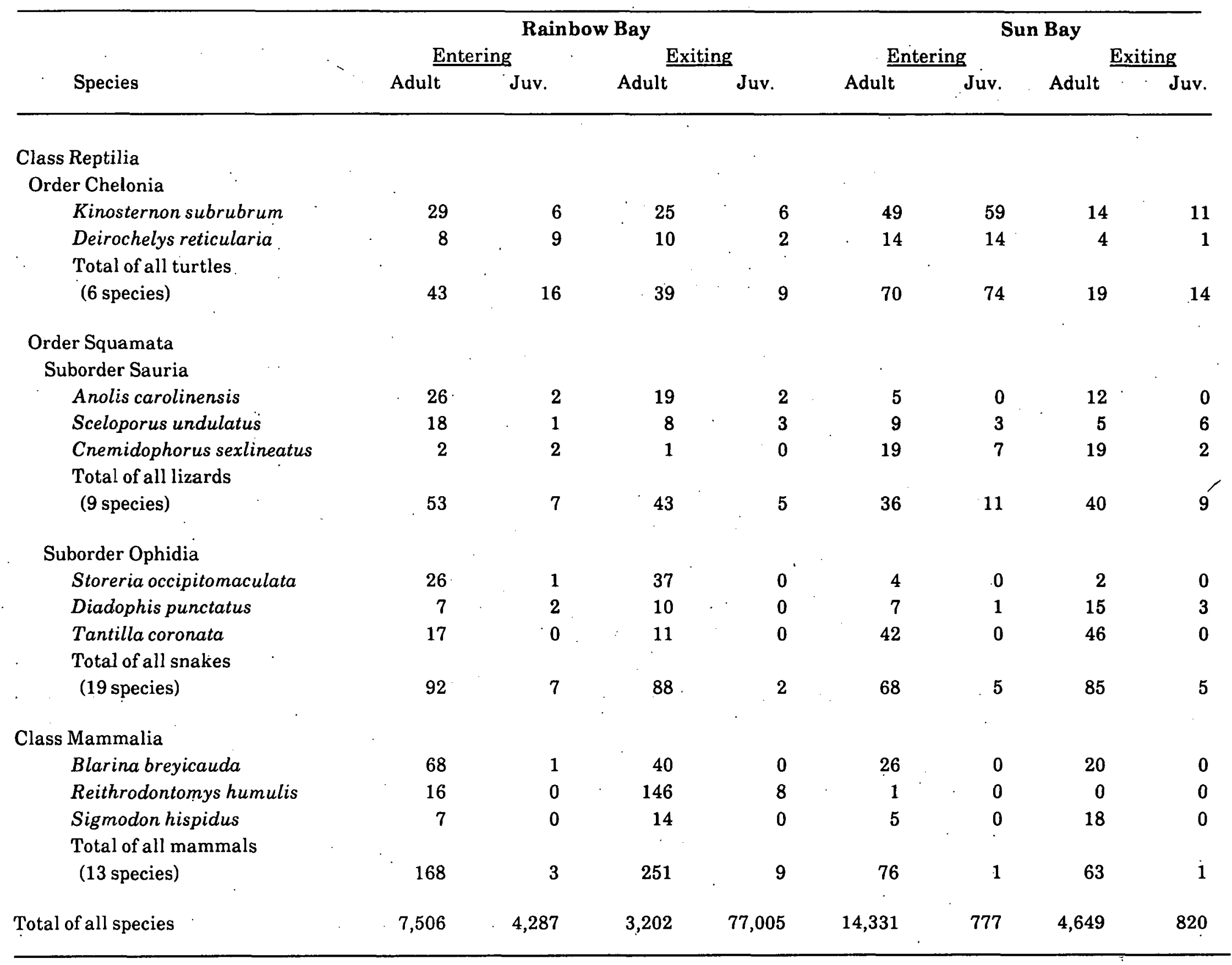


southern leopard frogs, and 500 mole salamanders entered or left Sun Bay, an area on the SRP of less than 1 ha completely drained by construction activity in the previous year. Similarly, Lost Lake on the SRP had been altered by agricultural practices prior to the 1950 s and, later, by the release of industrial by-products into the lake (Bennett et al. 1979). Half of this bay is now bordered by managed pine plantations. Nonetheless, extrapolation of captures by intermittent fencing and pitfall traps to the shoreline length bordered by the pine forest yielded estimates of 5,000 southern toads ( $B$ ufo terrestris), 2,000 mole salamanders, and 1,000 spadefoot toads (Scaphiopus holbrooki) that entered or left the lake in one summer.

Although amphibians are the prevalent terrestrial vertebrates utilizing Carolina bays (Patterson 1978, Bennett et al. 1979, Semlitsch 1981) and are a major contributor to secondary productivity, other vertebrates may be important in these communities as well. The American alligator (Alligator mississippiensis), six species of aquatic turtles (Table 12; Gibbons 1970), and several species of snakes (Table 12; Gibbons et al. 1977, Gibbons and Patterson 1978, Gibbons and Semlitsch 1990) are reptiles common to bays. Though quantitative data are unavailable, mammals such as deer, raccoons, skunks, and opossums may use bays for water or feeding sites. Beaver (Castor canadensis) have been noted in Thunder Bay and several other sites and could be an important agent in hardwood species composition and abundance. In sandhills regions of the Carolinas, many bird species including hawks, egrets, and migratory waterfowl use the bays during at least part of the year. Wood storks, an endangered bird species, have been observed foraging in Ellenton Bay. In bays with standing water and mature trees with cavities for nesting sites, wood ducks (Aix sponsa) may also be found (Mayer et al. 1986). The use of wood duck boxes placed as nesting sites in Carolina bays is common in some years (Brisbin and Hepp, personal observation). Again, quantitative estimates for all waterfowl species are lacking, but personal observations indicate the presence of such vertebrates in all water-containing Carolina bays that have been studied on the SRP.

Quantitative data are available for many small mammals using the periphery of Carolina bays (Table 12). Though shrews (Blarina brevicauda and Sorex longirostris) and small rodents (Sigmodon hispidus, Peromyscus gossypinus, and Microtus pinetorum) may be abundant, only certain species, e.g., the rice rat (Oryzomys palustris), actually inhabit the marshy areas. Many small mammals captured by drift fences and pitfall traps (Figure 24 in Gibbons and Semlitsch 1982) around Carolina bays are equally abundant in strictly terrestrial habitats in the region (Briese and Smith 1974, Brown 1980).

\section{RECOMMENDATIONS FOR RESEARCH AND CONSERVATION}

Additional rescarch is needed hefore we achieve a cumprehensive perspective of Carolina bays with respect to hydrology, soil and water characteristics, community composition, population distributions and dynamics, primary productivity and trophic dynamics, and ecological succession and stability; and before we understand their contribution to larger-scale processes of the southeastern Coastal Plain. Some features will be revealed only through long-term monitoring of representative sites and through extensive comparative surveys of undisturbed and humandisturbed sites. Much of the present knowledge of Carolina bay ecology has derived from studies using Carolina bays of the SRP, especially Ellenton (Site 176), Rainbow (Site 189), Sun (Site 45), and Thunder (Site 83) Bays. Comparisons of a wider variety of sites, particularly on an clevational gradient across the Coastal Plain, would be extremely useful for the development of models relating biotic structure and processes to hydrology and human alteration.

Sharitz and Gibbons (1982), after surveying existing information on shrub bogs (pocosins) and Carolina bays, concluded that certain research areas could provide the most useful information on basic ecology and perturbation responses: (1) measurement of specific hydrologic parameters such as transpiration and evaporation rates, groundwater exchanges, and soil permeabilities in representative sites (including both peat and clay-based bays); (2) more comprehensive studies of the physicalchemical limnology of bay surface waters and responses to commercial activities such as agriculture and silviculture; (3) regional analyses of the relationships between vegetation patterns and hydrology, soils, and land use history; (4) studies of the relationships of low $\mathrm{pH}$, water level fluctuations, and low nutrient availability to bay fauna; and (5) the short- and long-term effects of fire on various 
ecosystem properties. Emerging remote sensing technologies offer an excellent method for initial regional surveys of Carolina bay water levels, vegetational composition and dynamics, and perturbation responses. Such approaches, coupled with additional intensive studies of selected sites, could significantly enhance our understanding of these unique coastal plain ecosystems.

The local and regional abundance of bays, their relative isolation from surface hydrologic exchanges, and difficulties in conversion of some sites to agriculture or silviculture afford good opportunities for protection and conservation of a significant representation of bay community types. Currently, Ellenton Bay and Steel Creek Bay (Site 143) are designated as set-aside habitat reserves on the SRP. Additional conservation efforts at the SRP and elsewhere would facilitate research efforts and could help to preserve upland ecosystem processes and attributes such as local groundwater recharge, nutrient retention, enhanced primary production, maintenance of species diversity and habitat structures, wildlife watering and foraging, and vertebrate reproduction. Such processes may have critical but still poorly-understood values to coastal plain ecology.

\section{SUMMARY}

Carolina bays are a major feature of the SRP landscape. The 194 bays identified in this survey range from less than 0.1 ha to about 50 ha in size and support a variety of aquatic and wetland communities. Most of the bays have limited development of organic or peat substrates; soils are typically sandy clay loam underlain by clay hardpan. Many were ditched and drained for agricultural purposes prior to the SRP. However, few have been actively disturbed since the early 1950 s and most altered sites have undergone successional recovery.

Several physical characteristics of these wetlands dictate the development and status of their biota. Carolina bays are typically isolated wetlands that are largely fed by rain and shallow, low solute groundwater. Thus, they have a nutrient-poor, softwater, acidic chemistry which, in turn, restricts primary and secondary productivity and utilization of these systems to tolerant species. In addition, severe oscillations of their hydrology make these bays relatively unpredictable habitats. Although unexamined, the role of fire in these ecosystems may be very important. Interpretations of successional status or development of the biota must take this unpredictability into account and long-term observations will be necessary to understand the role of these bays in supporting aquatic and wetland organisms.

Much of the research to date on the Carolina. bays of the SRP and elsewhere has focused on certain species or on environmental features. Different levels of detail exist for different groups of organisms and reflect the diverse interests of previous investigators. This report summarizes aspects of research to date and presents data from numerous studies, but it does not attempt to synthesize. The most complete ecosystem study and synthesis of the biotic and abiotic properties of a single bay is the study of Thunder Bay (Site 83) by Schalles and Shure (1989). The most extensive comparison of SRP bays with those found throughout the Southeast was provided by Sharitz and Gibbons (1982). Coordinated efforts to integrate research in these systems and to relate properties and functions of these wetlands to those of other seasonal wetland systems are needed to understand and evaluate the role of these abundant ecosystems in the ecology of the southeastern Coastal Plain. 


\section{ACKNOWLEDGMENTS}

The bay mapping and field surveys of the senior author, the 18-site 1979-1980 water chemistry survey, and work related to the preparation of this report were supported by the U.S. Department of Energy National Environmental Research Pärk Program at the Savannah River Ecology Laboratory. We thank Alston Hodge for the data and ideas from his M.S. Thesis draft. His work added significant new information on bay soils and vegetation. Avis Newell was responsible for much of the field sampling in the 1979-1980 water chemistry comparisons of 18 bays and also performed many of the laboratory analyses. Jim Cahill of the U.S. Geological Survey in Columbia, SC, worked with the senior author on surface and groundwater hydrology studies at Thunder Bay and kindly allowed portions of this data to be used in this report. We also thank Barbara Taylor, Diane Mahoney, and Mona Mort for contributing a summary of their work on bay zooplankton and Mike Newman for providing water chemistry data for selected bays. Thanks to Jean Coleman for the preparation of several of the figures used in this report and to Jan Hinton, Teresa Taylor, and Miriam Stapleton for processing, typing, and proofing the manuscript. Finally, we gratefully acknowledge the editorial contributions made by Karen Patterson, Patricia West, Sally Landaal, and the recommendations of several anonymous reviewers.

This research was supported, in part, by National Environmental Research Park funds administered by the Savannah River Ecology Laboratory under Contract No DE-AC0976 SROO 819 between the University of Georgia and the United States Department of Energy: 


\section{LITERATURE CITED}

Auble, G. T. 1984. Dissolved cation concentrations in Okefenokee Swamp surface water: spatial and temporal variation. Pages 320-332 in A.D. Cohen, D.J. Casagrande, M.J. Adrejko, and G.R. Best, editors. The Okefenokee Swamp: its natural history, geology, and geochemistry. Wetland Surveys, Los Alamos, New Mexico, USA.

Bailey, J. R. and D. G. Frey. 1958. Darters of the genus Hololepis from some natural lakes of North Carolina. J. Elisha Mitchell Sci. Soc. 67:191-203.

Barnes, J. S. 1981. Agricultural adaptations of wet soils of the North Carolina coastal plain. Pages 225-237 in C.J. Richardson, editor. Pocosin Wetlands. Hutchinson Ross Publishing Company, Stroudsburg, Pennsylvania, USA.

Benke, A. C. 1976. Dragonfly production and prey turnover. Ecology 57:915-927.

Bennett, S. H., J. W. Gibbons, and J. Glanville. 1979. Terrestrial activity, abundance and diversity of amphibians in differently managed forest types. Am. Midl. Nat. 103:412-416.

Bennett, D. H. and R W. McFarlane. 1983. The Fishes of the Savannah River Plant: National Environmental Research Park. National Environmental Research Park Publication. U.S. Department of Energy and Savannah River Ecology Laboratory, Aiken, SC.

Bliley, D. J. and D. E. Pettry. 1979. Carolina bays on the eastern shore of Virginia. Soil Sci. Soc. of Am. 43:558-564.

Bosserman, R. W. 1979. The hierarchical integrity of Utricularia - periphyton microecosystems. Ph.D. Dissertation. University of Georgia, Athens, Georgia, USA.

Boyoucous, G. J. 1927. The hydrometer as a new method for the mechanical analysis of soils. Soil Sci. 23:343-353.
Briese, L. A. and M. H. Smith. 1974. Seasonal abundance and movement of nine species of small mammals. J. Mammal. 55:615-629.

Brown, K. W. 1980. An analysis of herptofaunal species diversity along a temporal gradient of loblolly pine stands in South Carolina. M.S. Thesis. Texas Christian University, Fort Worth, Texas, USA.

Bryant, J. P. and R. J. McCracken. 1964. Properties of soils and sediments of the Carolina bays. J. Elisha Mitchell Sci. Soc. 80:166.

Buell, M. F. 1939. Peat formation in the Carolina bays. Bull. Torrey Bot. Club 66:483-487.

1946. Jerome Bog, a peat-filled "Carolina bay." Bull. Torrey Bot. Club 73:2433.

Christensen, N., R. Burchell, A. Liggett, and E. Simms. 1981. The structure and development of pocosin vegetation. Pages 4361 in C.J. Richardson, editor. Pocosin Wetlands. Hutchinson Ross Publishing Company, Stroudsburg, Pennsylvania, USA.

Clymo, R. S. 1964. The origin of acidity in bogs. Bryologist 67:427-431.

Conant, R. 1975. A field guide to reptiles and amphibians. Houghton-Mifflin Company, Boston, Massachusetts, USA.

Cross, W. H. 1955. Anisopteran Odonata of the Savannah River Plant, South Carolina. J. Elisha Mitchell Sci. Soc. 71:9-17.

Daniel, C. 1981. Hydrology, geology, and soils of pocosins: a comparison of natural and altered systems. Pages 69-108 in C.J. Richardson, editor. Pocosin Wetlands. Hutchinson Ross Publishing Company, Stroudsburg, Pennsylvania, USA.

Dierberg, F. E. and P, L. Brezonik. 1984. Water chemistry of a Florida cypress dome. Pages 34-50 in K.C. Ewel and H.T. Odum, editors. Cypress Swamps. University of Florida Press, Gainesville, F'lorida, USA. 
Frey, D. G. 1949. Morphometry and hydrography of some natural lakes of the North Carolina coastal plain: the bay lake as a morphometrtic type. J. Elisha Mitchell Sci. Soc. 65:1-37.

1950. Carolina bays in relation to the North Carolina coastal plain. J. Elisha Mitchell Sci. Soc. 66:44-52.

1951. The fishes of North Carolina's bay lakes and their intraspecific variation. $J$. Elisha Mitchell Sci. Soc. 67:1-44.

1953. Regional aspects of the late-glacial and post-glacial pollen succession of southeastern North Carolina. Ecol. Monogr. 23:289-313.

1955. Stages in the ontogeny of the Carolina bays. Verhandlungen Internationale Vereinigung fur Theortische und Angewandte Limnologie 12:660-668.

Gamble, E. E., R. B. Daniels, and W. H. Wheeler. 1977. Primary and secondary rims of Carolina bays. Southeast. Geol. 18:199-211.

Gibbons, J. W. 1970: Terrestrial activity and the population dynamics of aquatic turtles. Am. Midl. Nat. 83:404-414.

Gibbons, J. W. and K. K. Patterson. 1978. The Reptiles and Amphibians of the Savannah River Plant. National Environmental Research Park Publication. U:S. Department of Energy and Savannah River Ecology Laboratory, Aiken, SC.

Gibbons, J. W. and R. D. Semlitsch. 1982. Terrestrial drift fences with pitfall traps: an effective technique for quantitative sampling of animal populations. Brimleyana 1982(7):116.

Gibbons, J. W. and R. D. Semlitsch. 1990. A Guide to the Reptiles and Amphibians of the Savannah River Plant. National Environmental Research Park Publication. U.S. Department of Energy and Savannah River Ecology Laboratory, Aiken, SC. (In Press)
Gibbons, J. W., J. W. Coker, and T. M. Murphy. 1977. Selected aspects of the life history of the rainbow snake (Farancia erytrogramma). Herpetologica 33:271-281.

Gibbs, R. J. 1970. Mechanisms controlling world water chemistry. Science 1970:1088-1090.

Heimberg, K. 1976. Hydrology of some northcentral Florida cypress domes. M. S. Thesis. University of Florida, Gainesville, Florida, USA.

Hodge, A. E. 1985. Untitled draft M.S. Thesis on Carolina bays on and adjacent to the SRP. Clemson University, Clemson, South Carolina, USA.

Hutchinson, G. E. 1957. A treatise on limnology. I: Geography, physics, and chemistry. John Wiley and Sons; Incorporated, New York, New York, USA.

Ingram, R. L. and L. J. Otte. 1981. Peat in North Carolina wetlands. in C.J. Richardson, editor. Pocosin Wetlands. Hutchinson Ross Publishing Company, Stroudsburg, Pennsylvania, USA.

Ingram, R. L., M. Robinson, and H. T. Odum. 1959. Clay mineralogy of some Carolina bay sediments. Southeast. Geol. 1:1-10.

Johnson, D. 1942. The Origin of the Carolina bays. Columbia University Press, New York, New York, USA.

Jones, R. H. 1981. A classification of lowland forests in the northern coastal plain of South Carolina. M. S. Thesis. Clemson University, Clemson, South Carolina, USA.

Kelley, W. R. and W. T. Batson. 1955. An ecological study of the land plants and cold-blooded vertebrates of the Savannah River project area. Part VI. Conspicuous vegetational zonation in a "Carolina bay." University of South Carolina Publication Series III. Biology 1:244-248.

Kormondy, E. J. 1968. Weight loss of cellulose and aquatic macrophytes in a Carolina bay. Limnol. and Oceanogr. 13:522-526. 
Lichtler, W. F. and P. N. Walker. 1979. Hydrology of the Dismal Swamp. Pages 140-168 in P.W. Kirk, editor. The Great Dismal Swamp. The University of Virginia Press, Charlottesville, Virginia, USA.

Livingstone, D. A. 1963. Chemical composition of rivers and lakes. Chapter 6. Data on Geochemistry, 6th edition. Professional Paper, United States Geological Survey 440G, Washington, D.C., USA.

MacKinzie, W. E. 1974. Criteria used in soil taxonomy to classify organic soils. Pages 1-10 in A.R. Aandahl, editor. Histosols: their characteristics, classification, and use. Soil Science Society of America Special Publication Number 6, Soil Science Society of America, Madison, Wisconsin, USA.

Mayer, J. J., R. A. Kennamer, and R. T. Hoppe. 1986. Waterfowl of the Savannah River Plant. Stress and Wildlife Ecology Division Report. Savannah River Ecology Laboratory, Aiken, SC.

Patrick, R., B. Matson, and L. Anderson. 1979. Streams and lakes in the Pine Barrens. Pages 169-194 in R.T.T. Forman, editor. Pine Barrens; ecosystem and landscape. Academic Press, New York, New York, USA.

Patterson, K. 1978. Life history patterns of paedogenic populations of the mole salamander, Ambystoma talpoideum. Copeia 1978:649-655.

Perdue, E. M., J. H. Reuter, and M. Ghosal. 1984. The operational nature of acidic functional group analysis and its impact on mathematical descriptions of acid-base equilibria in humic substances. Geochemica et Cosmochimica Acta 44:1841-1851.

Polisini, J. M., C. E. Boyd, and B. Didgeon. 1970. Nutrient limiting factors in an oligotrophic South Carolina pond. Oikos 21:344-347.

Price, W. A. 1968. Carolina bays. Pages 102-108 in R.W. Fairbridge, editor. Encyclopedia of Geomorphology. Reinhold Book Corporation, New York, New York, USA.
Prouty, W. F. 1952. Carolina bays and their origin Bull. Geol. Soc. Am. 63:167-224.

Richardson, C. J., R. Evans, and D. Carr. 1981 Pocosins: an ecosystem in transition. Pages 3-19 in C.J. Richardson, editor. Pocosin Wetlands. Hutchinson Ross Publishing Company, Stroudsburg, Pennsylvania, USA.

Savannah River Ecology Laboratory. 1980. A biological inventory of the proposed site of the defense waste processing facility on the Savannah River Plant in Aiken, South Carolina. Annual Report. Savannah River Ecology Laboratory, Aiken, SC.

Schalles, J. R. 1979. Comparative limnology and ecosystem analysis of Carolina bay ponds on the upper coastal plain of South Carolina. Ph.D. Dissertation, Emory University, Atlanta, Georgia, USA.

Schalles, J. F. 1989. Comparative chemical limnology of Carolina bay wetlands on the upper coastal plain of South Carolina. In R. R. Sharitz and J. W. Gibbons, editors. Freshwater Wetlands and Wildlife: Perspectives on Natural, Managed, and Degraded Ecosystems. U.S. D.O.E. Symp. Ser. CONF 860130. (In Press).

Schalles, J. R. and D. J. Shure. 1989. Hydrology, community structure, and productivity of a dystrophic Carolina bay. wetland. Ecol. Monogr. (In Press).

Semlitsch, R. D. 1981. Terrestrial activity and summer home range of the mole salamander (Ambystoma talpoideum). Can. J. Zool. 59:315-322.

1985. Reproductive strategy of a facultatively paedomorphic salamander Ambystoma talpoideum. Oecologia 65:305313.

Sharitz, R. R. and J. W. Gibbons. 1982. The ecology of southeastern shrub bogs (Pocosins) and Carolina bays: a community profile. Fish and Wildlife Service, United States Department of the Interior, Atlanta, Georgia, USA. 
Shields, J. D., N. D. Woody, A. S. Dicks, G. J. Hollod, J. Schalles, and G. J. Leversee. 1982. Locations and areas of ponds and Carolina bays at the Savannah River Plant. E.I. du Pont Nemours and Company, Savannah River Laboratory, Aiken, South Carolina, USA.

Siple, G. E. 1967. Geology and groundwater of the Savannah River Plant and vicinity, South Carolina. United States Geological Survey Water Supply Paper 1841, Washington, D.C., USA.

Taylor, B. E., R. A. Estes, J. H. K. Pechmann, and R. D. Semlitsch. 1988. Trophic relations in a temporary pond: larval salamanders and their microinvertebrate prey. Can. J. Zool. 66:2191:2198.

Taylor, B. E., D. L. Mahoney, and R. A. Estes. 1989. Zooplankton production in a Carolina bay. In R. R. Sharitz and J. W. Gibbons, editors. Freshwater Wetlands änd Wildlife: Perspectives on Natural, Managed, and Degraded Ecosystems. U.S. D.O.E. Symp. Ser. CONF 860130. (In Press).

Tilly, L. J. 1973. Comparative productivity of four Carolina lakes. Am. Midl. Nat. 90:356-365.

1975. Changes in water chemistry and primary productivity of a reactor cooling reservoir (Par Pond). Pages 394-407 in F.G. Howell, J.B. Gentry, and M.H. Smith, editors. Mineral cycling in southeastern ecosystems. United States Energy Research and Development Administration, Springfield, Virginia, USA.

Wells, B. W. and S. G. Boyce. 1953. Carolina bays: Additional data on their origin, age and history. J. Elisha Mitchell Sci. Soc. 69:119141.

Wells, B. W. and L. A. Whitford. 1976. History of stream head swamp forests, pocosins, and savannahs in the Southeast. J. Elisha Mitchell Sci. Soc. 92:148-150.

Wetzel, R: G. 1983. Limnology. Second Edition. Saunders College Publishing, Philadelphia, Pennsylvania, USA.
Wharton, C. H. 1978. The natural environments of Georgia. Georgia Department of Natural Resources, Atlanta, Georgia, USA.

Whitehead, D. R. 1973. Late-Wisconsin vegetational changes in unglaciated eastern North America. Quater. Res. 3:621-631.

Woodwell, G. M. 1958. Factors controlling growth of Pond Pine seedlings in organic soils of the Carolinas. Ecol. Monogr: 28:219-236. 
Appendix I. Areas and locations of Carolina bays at the SRP. Bay numbers correspond to those in Figure 1.

\begin{tabular}{|c|c|c|c|c|c|c|}
\hline $\begin{array}{l}\text { Bay } \\
\text { Number }\end{array}$ & $\begin{array}{l}\text { Bay } \\
\text { Name }\end{array}$ & $\begin{array}{c}\text { Grid } \\
\text { East }\end{array}$ & $\begin{array}{l}\text { dinates } \\
\text { North }\end{array}$ & $\begin{array}{l}\text { SRP Patrol } \\
\text { Coordinates }\end{array}$ & $\begin{array}{l}\text { Area } \\
\text { Acres* }\end{array}$ & $\begin{array}{c}\text { Habitat } \\
\text { Type }\end{array}$ \\
\hline $\begin{array}{l}1 \\
2+ \\
3 \\
4 \\
5 \\
6 \\
7 \\
8+ \\
9 \\
10\end{array}$ & $\begin{array}{l}\text { Sweet Gum Bay } \\
\text { Flamingo Bay } \\
\text { Fire Pond }\end{array}$ & $\begin{array}{l}61000 \\
62000 \\
64000 \\
64000 \\
33000 \\
33000 \\
32500 \\
34500 \\
35000 \\
35500\end{array}$ & $\begin{array}{r}98500 \\
99000 \\
93000 \\
96500 \\
103000 \\
101500 \\
96000 \\
96500 \\
97000 \\
97500\end{array}$ & $\begin{array}{l}\text { D-15 } \\
\text { D-15 } \\
\text { E-16 } \\
\text { D-15 } \\
\text { C-8 } \\
\text { C-8 } \\
\text { D-8 } \\
\text { D-8 } \\
\text { D-8 } \\
\text { D-8 }\end{array}$ & $\begin{array}{r}3.7 \\
9.3 \\
14.0 \\
3.2 \\
2.4 \\
11.2 \\
6.2 \\
2.5 \\
4.3 \\
0.3\end{array}$ & $\begin{array}{l}\text { forested/herbaceous } \\
\text { forested } \\
\text { herbaceous** } \\
\text { forested/herbaceous } \\
\text { herbaceous } \\
\text { forested } \\
\text { herbaceous } \\
\text { herbaceous } \\
\text { herbaceous } \\
\text { herbaceous }\end{array}$ \\
\hline $\begin{array}{l}11 \\
12+ \\
13+ \\
14 \\
15 \\
16 \\
17+ \\
18+ \\
19+ \\
20+\end{array}$ & $\begin{array}{l}\text { Odum Bay } \\
\text { Golley Bay } \\
\text { Ginger's Bay }\end{array}$ & $\begin{array}{l}36500 \\
36500 \\
37000 \\
36000 \\
35500 \\
35000 \\
36500 \\
30000 \\
29500 \\
28500\end{array}$ & $\begin{array}{r}98000 \\
96000 \\
95000 \\
94500 \\
95000 \\
95000 \\
104500 \\
90000 \\
89500 \\
90500\end{array}$ & $\begin{array}{l}\text { D-9 } \\
\text { E-9 } \\
\text { E-9 } \\
\text { E-9 } \\
\text { E-8 } \\
\text { E-8 } \\
\text { B-9 } \\
\text { F-7 } \\
\text { F-7 } \\
\text { F-7 }\end{array}$ & $\begin{array}{r}1.9 \\
1.9 \\
3.7 \\
3.7 \\
2.5 \\
5.0 \\
3.7 \\
<0.3 \\
0.3 \\
3.7\end{array}$ & $\begin{array}{l}\text { herbaceous } \\
\text { herbaceous } \\
\text { forested/herbaceous } \\
\text { herbaceous } \\
\text { herbaceous } \\
\text { herbaceous } \\
\text { herbaceous } \\
\text { herbaceous/forested } \\
\text { forested. } \\
\text { herbaceous }\end{array}$ \\
\hline
\end{tabular}


Appendix I. Continued

\begin{tabular}{|c|c|c|c|c|c|c|}
\hline $\begin{array}{l}\text { Bay } \\
\text { Number }\end{array}$ & $\begin{array}{l}\text { Bay } \\
\text { Name }\end{array}$ & $\begin{array}{l}\text { Grid } \\
\text { East }\end{array}$ & $\begin{array}{l}\text { inates } \\
\text { North }\end{array}$ & $\begin{array}{l}\text { SRP Patrol } \\
\text { Coordinates }\end{array}$ & $\begin{array}{l}\text { Area } \\
\text { Acres* }\end{array}$ & $\begin{array}{c}\text { Habitat } \\
\text { Type }\end{array}$ \\
\hline
\end{tabular}

\begin{tabular}{|c|c|c|c|c|c|c|}
\hline $21+$ & & 27000 & 89500 & F-6 & 1.9 & herbaceous \\
\hline $22+$ & & 26000 & 90000 & F-6 & $<0.3$ & forested/herbaceous \\
\hline 23 & \multirow[t]{2}{*}{ Snake and Mosquito Bay } & 25500 & 89000 & F-6 & 3.7 & herbaceous \\
\hline 24 & & 26500 & 88500 & $F \div 6$ & 1.6 & forested/herbaceous \\
\hline 25 & Fern Bay & 28500 & 84500 & G-7 & 2.5 & forested/herbaceous \\
\hline 26 & Caroline's Bay & 26500 & 81500 . & H-6 & 1.2 & herbaceous \\
\hline 27 & Morse Code Bay & 27000 & 81500 & H-6 & 1.9 & herbaceous \\
\hline 28 & Lost Lake & .47000 & 101500 & C-11 & 5.0 & \\
\hline 29 & & 48000 & 102000 & C-11 & 0.3 & \\
\hline 30 & & 61000 & 84500 & G-15 & 1.9 & herbaceous** \\
\hline 31 & Dry Bay. & 29000 & 80000 & $\mathrm{H}-7$ & 12.4 & herbaceous** \\
\hline $32+$ & & 71000 & 76000 & H-17 & 9.3 & forested \\
\hline $33+$ & & 73000 & 76000 & $J-18$ & 12.4 & forested/herbaceous \\
\hline $34+$ & & 78000 & 68000 & L-19 & 4.3 & forested \\
\hline 35 & & 72000 & 65000 & L-17 & 3.1 & herbaceous \\
\hline $36+$ & & 83500 & 62000 & M-18 & 3.1 & herbaceous \\
\hline $37+$ & & 71500 & 62000 & M-17 & 2.5 & forested \\
\hline $38+$ & Huffin-Puff Bay & 71000 & 63500 & M-17 & 20.5 & forested/herbaceous \\
\hline $39+$ & & 69000 & 59000 & $\mathrm{~N}-17$ & 1.2 & forested \\
\hline 40 . & Enchantment Bay & 67000 & 60000 & M-16 & 13.0 & herbaceous** \\
\hline
\end{tabular}


Appendix I. Continued

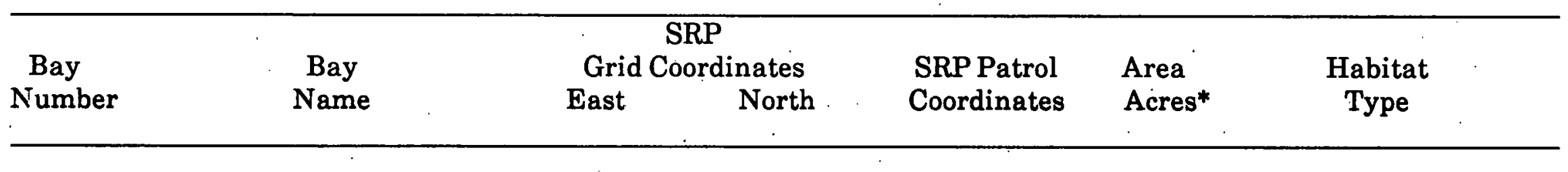

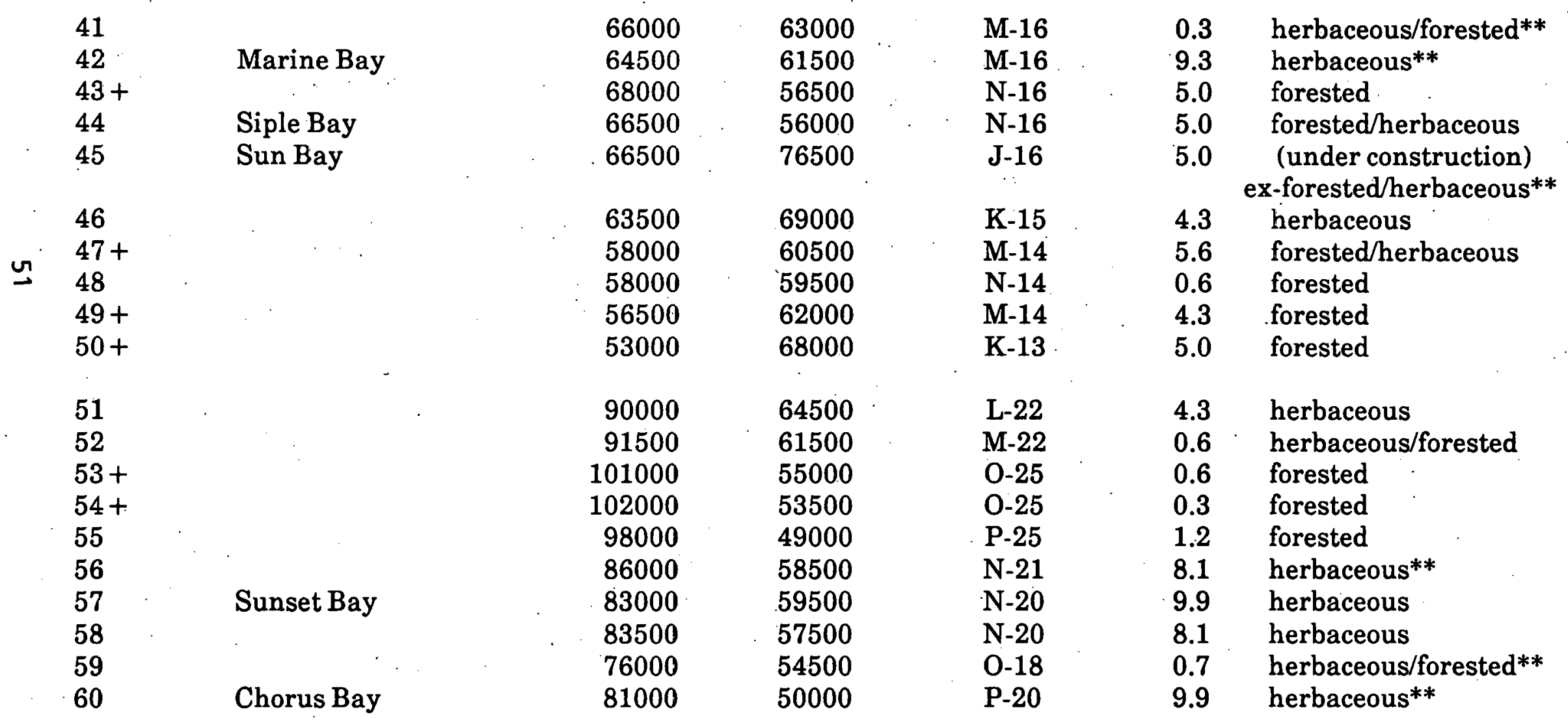


Appendix I. Continued

\begin{tabular}{|c|c|c|c|c|c|c|}
\hline $\begin{array}{l}\text { Bay } \\
\text { Number }\end{array}$ & $\begin{array}{c}\text { Bay } \\
\text { Name }\end{array}$ & \multicolumn{2}{|c|}{$\begin{array}{c}\text { SRP } \\
\text { Grid Coordinates }\end{array}$} & $\begin{array}{l}\text { SRP Patrol } \\
\text { Coordinates }\end{array}$ & $\begin{array}{l}\text { Area } \\
\text { Acres* }\end{array}$ & $\begin{array}{c}\text { Habitat } \\
\text { Type }\end{array}$ \\
\hline 61 & & 72500 & 53500 & $0-18$ & 13.0 & forested/herbaceous \\
\hline 62 & Janell's Bay & 81000 & 45500 & Q-20 & 1.9 & herbaceous** \\
\hline 63 & & 92000 . & 39000 & S-22 & 1.7 & \\
\hline 64 & Little Cypress Bay & 91000 & 37500 & S-22 & 1.7 & \\
\hline 65 & & 111500 & 53000 & P-27 & 2.5 & herbaceous \\
\hline 66 & Mona Bay & 110000 & 52000 & P-27 & 27.9 & herbaceous** \\
\hline 67. & Woodward Bay & 109000 & 52000 & P-27 & 17.4 & herbaceous** \\
\hline 68 & & 107000 & 51500 & P-26 & 3.7 & herbaceous \\
\hline 69 & & 106500 & 51000 & .26 & 2.4 & herbaceous \\
\hline 70 & & 105500 & 49500 & P-26 & 6.8 & forested/herbaceous \\
\hline 71 & & 107000 & 49000 & P-26 & 4.3 & herbaceous \\
\hline 72 & & 108000 & 47500 & $\mathrm{Q}-26$ & 3.1 & herbaceous \\
\hline 73 & & 107000 & 47500 & Q-26 & 4.3 & herbaceous \\
\hline 74 & & 105500 & 45000 & $\mathrm{Q}-26$ & 0.3 & herbaceous \\
\hline 75 & & 98000 & 50000 & P-24 & 0.6 & \\
\hline 76 & & 105000 & 43000 & $\mathrm{R}-26$ & 0.6 & herbaceous** \\
\hline 77 & Craig's Pond & 102500 & 43500 & $\mathrm{R}-25$ & 124.0 & herbaceous** \\
\hline 78 & Sarracenia Bay & 101500 & 45000 & Q-25 & 9.9 & herbaceous** \\
\hline 79 & & 100500 & 44500 & Q-25 & 1.2 & herbaceous \\
\hline 80 & Buttress Bay & 100000 & 44000 & $\mathrm{R}-24$ & 5.0 & forested \\
\hline 81 & & 95500 & 39500 & S-23 & 9.3 & herbaceous \\
\hline 82 & & 93500 & 38000 & S-23 & 1.9 & \\
\hline 83 & Thunder Bay & 88000 & 29500 & $\mathrm{U}-22$ & $10: 9$ & herbaceous** \\
\hline 84 & Par Pond Bay & 80000 & 39000 & S-20 & 5.0 & $\begin{array}{l}\text { open water (Michael's } \\
\text { Marsh of Par Pond) }\end{array}$ \\
\hline
\end{tabular}


Appendix I. Continued

\begin{tabular}{|c|c|c|c|c|c|}
\hline $\begin{array}{c}\text { Bay } \\
\text { Number }\end{array}$ & $\begin{array}{c}\text { Bay } \\
\text { Name }\end{array}$ & $\begin{array}{c}\text { SRP } \\
\text { Grid Coordinates } \\
\text { East }\end{array}$ & SRP Patrol & $\begin{array}{l}\text { Area } \\
\text { Acres* }\end{array}$ & $\begin{array}{c}\text { Habitat } \\
\text { Tuno }\end{array}$ \\
\hline Number & Name & East & Coordinates & Acres* & Type \\
\hline
\end{tabular}

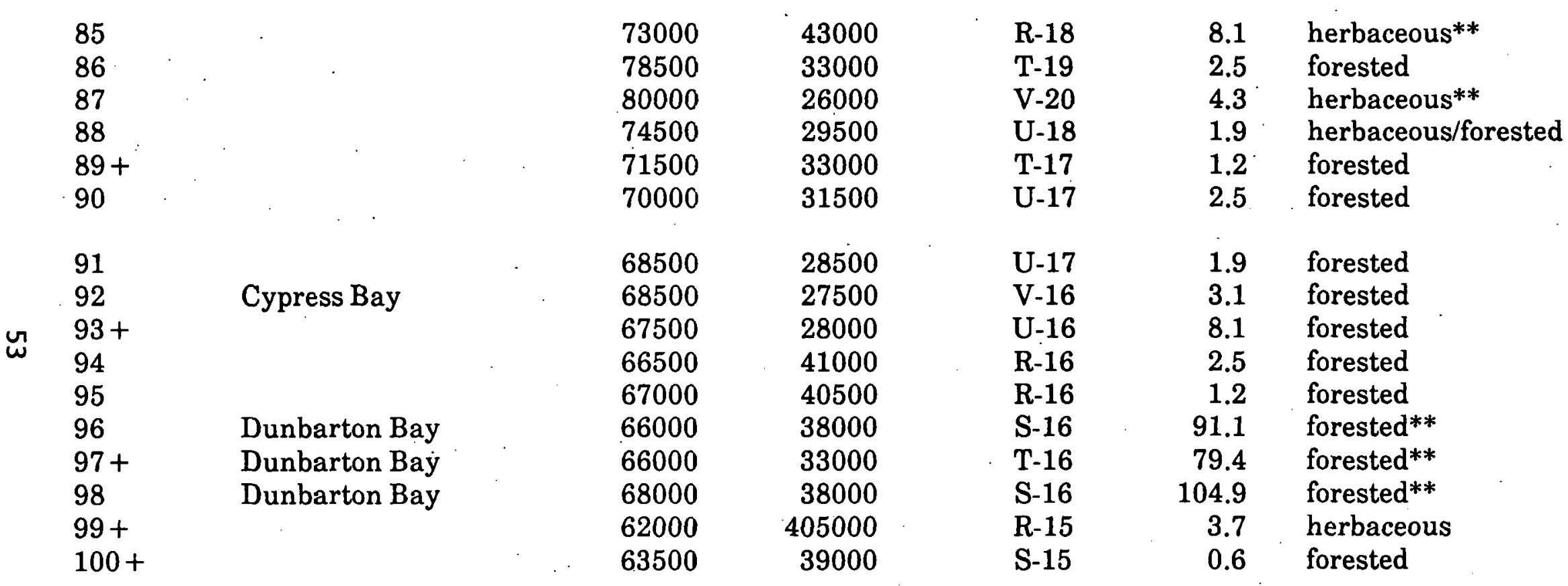


Appendix I. Continued

\begin{tabular}{|c|c|c|c|c|c|c|c|}
\hline \multirow{2}{*}{$\begin{array}{c}\text { Bay } \\
\text { Number }\end{array}$} & \multirow{2}{*}{\multicolumn{2}{|c|}{$\begin{array}{l}\text { Bay } \\
\text { Name }\end{array}$}} & \multicolumn{2}{|c|}{$\begin{array}{c}\text { SRP } \\
\text { Grid Coordinates }\end{array}$} & \multirow{2}{*}{$\begin{array}{l}\text { SRP Patrol } \\
\text { Coordinates }\end{array}$} & \multirow{2}{*}{$\begin{array}{l}\text { Area } \\
\text { Acres* }\end{array}$} & \multirow{2}{*}{$\begin{array}{c}\text { Habitat } \\
\text { Type }\end{array}$} \\
\hline & & & East & North & & & \\
\hline 101 & & & 62000 & 37000 & S-15 & 1.2 & forested \\
\hline $102+$ & & & 60000 & 32000 & T-15 & 1.2 & herbaceous \\
\hline $103+$ & & & 58500 & 32000 & T-14 & 4.3 & herbaceous \\
\hline $104+$ & & & 54000 & 28500 & U-13 & 6.8 & \\
\hline 105 & & & 56000 & 19000 & $\mathrm{X}-13$ & 5.6 & herbaceous/forested \\
\hline 106 & & & 53000 & 17000 & $X-13$ & 6.2 & forested \\
\hline 107 & & & 56000 & 14000 & Y-13 & 5.0 & herbaceous/forested \\
\hline $108+$ & . & & 66000 & 49500 & P-16 & 3.1 & herbaceous/forested \\
\hline $109+$ & & & 66000 & 48500 & P-16 & 7.4 & herbaceous \\
\hline 110 & & & 64500 & 46000 & Q-16 & 1.9 & herbaceous \\
\hline 111 & & & 61000 & 47500 & Q-15 & 0.3 & forested/herbaceous \\
\hline 112 & & & 61500 & 47500 & $Q-15$ & 0.3 & forested/herbaceous \\
\hline $113+$ & & & 59000 & 47000 & Q-14 & 3.1 & herbaceous $* * *$ \\
\hline 114 & & & 61500 & 44000 & $Q-15$ & 1.2 & herbaceous \\
\hline $115+$ & & & 62000 & 47000 & $Q-15$ & 9.9 & forested \\
\hline 116 & & & 57000 & 46000 & $Q-14$ & 1.2 & herbaceous** \\
\hline $117+$ & & & 61500 & 41000 & $\mathrm{R}-15$ & 1.2 & forested/herbaceous \\
\hline 118 & Hal's Bay & . & 57000 & 39000 & S-14 & 2.5 & herbaceous \\
\hline $119+$ & & & 61000 & 42000 & R-15 & 2.5 & forested \\
\hline 120 & Rt. 9 Bay & & 53000 & 35500 & T.13 & 1.9 & herbaceous*** \\
\hline
\end{tabular}


Appendix.I. Continued

\begin{tabular}{cccccc}
\hline & \multicolumn{2}{c}{ SRP } & & & \\
Bay & Bay & Grid Coordinates & SRP Patrol Area & Area \\
Number & Name & East & North & Coordinates Acres* & Type \\
\hline
\end{tabular}

\begin{tabular}{|c|c|c|c|c|c|c|}
\hline 121 & & 55000 & 57000 & $N-13$ & 3.7 & forested \\
\hline 122 & & 53500 & 61500 & M-13 & 5.6 & forested \\
\hline 123 & & 48500 & 64500 & L-12 & 1.9 & herbaceous** \\
\hline 124 & & 47000 & 61500 & M-11 & 3.5 & forested/herbaceous \\
\hline 125 & & 48000 & 61500 & M-11 & 5.0 & forested/herbaceous \\
\hline 126 & & 49000 & 61000 & M-12 & 0.6 & forested/herbaceous \\
\hline 127 & Castor Bay & 48000 & 59000 & $\mathrm{~N}-11$ & 8.7 & herbaceous** \\
\hline $128+$ & $x^{\circ}$ & 49000 & 58500 & $\mathrm{~N}-12$ & 5.0 & forested/herbaceous \\
\hline 129 & & 51000 & 58000 & $\mathrm{~N}-12$ & 1.2 & forested \\
\hline 130 & & 46500 & 58000 & $N-11$ & 6.8 & herbaceous \\
\hline 131 . & & 49500 & 58000 & $\mathrm{~N}-12$ & 2.5 & herbaceous \\
\hline 132 & Wells Bay & 45000 & 53500 & $0-11$ & 7.4 & forested \\
\hline $133+$ & & 39000 & 43000 & R-9 & 1.2 & \\
\hline 134 & & 38000 & 42500 & R-9 & 1.2 & forested/herbaceous \\
\hline 135 & & 36000 & 43000 & $4-8$ & 2.5 & forested \\
\hline 136 & & 31500 & 40500 & R-7 & 1.7 & herbaceous** \\
\hline $137+$ & & 29500 & 38000 & S-7 & 1.8 & herbaceous** \\
\hline 138 & Small Robbin's Bay & 31500 & 37500 & S-7 & 1.9 & herbaceous \\
\hline 139 & Big Robbin's Bay & 31500 & 36500 & S-7 & 1.2 & herbaceous \\
\hline 140 & & 33500 & 35500 & $\mathrm{~T}-8$ & 3.7 & \\
\hline
\end{tabular}


Appendix I. Continued

\begin{tabular}{cccccc}
\hline $\begin{array}{c}\text { Bay } \\
\text { Number }\end{array}$ & Bay & \multicolumn{2}{c}{ SRP } & SRid Coordinates & SRP Patrol \\
Name & East & North & Coordinates & $\begin{array}{l}\text { Area } \\
\text { Acres* }\end{array}$ & $\begin{array}{c}\text { Habitat } \\
\text { Type }\end{array}$ \\
\hline
\end{tabular}

\begin{tabular}{|c|c|c|c|c|c|c|}
\hline 141 & & 33500 & 35000 & T-8 & 1.0 & \\
\hline 142 & Peat Bay & 35000 & 33000 & T-8 & 14.3 & \\
\hline $143+$ & Steel Creek Bay & 32500 & 28000 & $\mathrm{~V}-8$ & 1.2 & \\
\hline $144+$ & & 45000 & 23000 & W-11. & 1.9 & forested \\
\hline $145+$ & & 45000 & 21500 & W-11 & 3.1 & herbaceous/forested \\
\hline $146+$ & & 45000 & 20000 & W-11 & 1.9 & herbaceous \\
\hline 147 & & 37000 & 22500 & W-9 & 5.0 & \\
\hline 148 & & 32500 & 20000 & $\mathrm{X}-8$ & 0.3 & \\
\hline 149 & & 33000 & 19500 & $X-8$ & 1.2 & \\
\hline 150 & & 35000 & 18500 & $\mathrm{X}-8$ & 0.3 & \\
\hline 151 & & 30500 & 18000 & $X=7$ & 0.3 & \\
\hline $152+$ & & 26000 & 40000 & R-6 & 3.7 & herbaceous \\
\hline $153+$ & & 25000 & 41500 & R-6 & 2.5 & herbaceous \\
\hline $154+$ & & 24500 & 41500 & R-6 & 1.9 & forested \\
\hline $155+$ & & 24500 & 41500 & $\mathrm{R}-6$ & 5.0 & herbaceous** \\
\hline $156+$ & & 30000 & 44500 & Q-7 & 1.9 & herbaceous \\
\hline 157 & & 29000 & 44000 & Q-7 & $<0.3$ & herbaceous/forested \\
\hline 158 & & 29000 & 44500 & Q-7 & $<0.3$ & herbaceous/forested \\
\hline 159 & & 29000 & 45000 & Q-7 & $<0.3$ & herbaceous/forested \\
\hline $160+$ & & 28000 & 45000 & Q-7 & 1.2 & forested \\
\hline
\end{tabular}


Appendix I. Continued

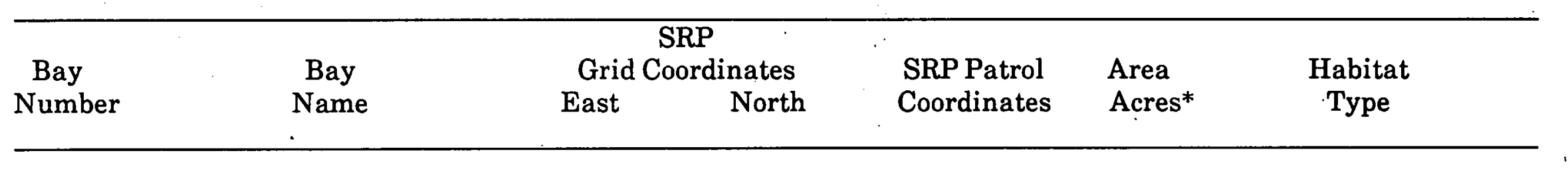

$\begin{array}{llccccl}161+ & & 21500 & 51000 & \mathrm{P}-5 & 3.7 & \text { herbaceous } \\ 162+ & & 24000 & 52000 & \mathrm{P}-5 & 0.6 & \text { herbaceous/forested } \\ 163 & & 24000 & 52500 & \mathrm{O}-6 & 1.9 & \text { herbaceous } \\ 164 & & 25500 & 54500 & \mathrm{O}-6 & 2.5 & \text { herbaceous/forested } \\ 165 & \text { Buell Bay } & 22500 & 54500 & \mathrm{O}-5 & 2.5 & \text { herbaceous } \\ 166+ & & 22500 & 54500 & \mathrm{O}-5 & <0.3 & \text { forested } \\ 167+ & & 18000 & 54000 & \mathrm{O}-4 & 2.0 & \text { forested/herbaceous } \\ 168 & \text { Frey Bay } & 20000 & 56000 & \mathrm{~N}-4 & 2.0 & \text { herbaceous } \\ 169+ & & 21000 & 57000 & \mathrm{~N}-5 & 0.5 & \text { forested } \\ 170 & \text { Prouty Bay } & 28000 & 59000 & \mathrm{~N}-6 & 3.1 & \text { herbaceous/forested** } \\ & & & & & & \\ 171 & \text { Johnson Bay } & 34000 & 57000 & \mathrm{~N}-8 & 1.7 & \text { herbaceous** } \\ 172 & \text { Barbara's Bay } & 40000 & 59000 & \mathrm{~N}-10 & 1.9 & \text { forested** } \\ 173 & \text { Seal Oil Bay } & 23000 & 67500 & \mathrm{~L}-5 & 3.1 & \text { herbaceous } \\ 174 & \text { Idlewild Bay } & 23000 & 69000 & \mathrm{~K}-5 & 7.4 & \text { herbaceous/forested } \\ 175 & \text { Woods Bay } & 21000 & 70500 & \mathrm{~K}-5 & 3.7 & \text { herbaceous } \\ 176 & \text { Ellenton Bay } & 22000 & 72000 & \mathrm{~K}-5 & 27.9 & \text { herbaceous } \\ 177+ & & 43000 & 58500 & \mathrm{~N}-10 & 5.2 & \text { herbaceous } \\ 178 & \text { Asphalt Bay } & 24000 & 66500 & \mathrm{~L}-5 & 5.1 & \text { herbaceous } \\ 179 & & 19000 & 73000 & \mathrm{~J}-4 & 2.5 & \text { herbaceous } \\ 180 & & 19000 & 76000 & \mathrm{~J}-4 & 0.6 & \text { forested }\end{array}$


Appendix I. Continued

\begin{tabular}{lcccc}
\hline Bay & \multicolumn{2}{c}{ SRP } & & \\
Number & Bay & Grid Coordinates & SRP Patrol & Area \\
Coordinates & Acres* Habitat \\
Name & East $\quad$ North & Type \\
\hline
\end{tabular}

$\begin{array}{llrrrrl}181+ & & 36500 & 91000 & \text { F-9 } & 0.6 & \text { herbaceous } \\ 192+ & & 35000 & 89000 & \text { F-8 } & 2.5 & \text { forested } \\ 183+ & & 36000 & 92000 & \text { F-8 } & \text { : } \\ 184+ & \text { Diane's Bay } & 68000 & 105000 & \text { C-17 } & 0.4 & \text { herbaceous/forested** } \\ \text { herbaceous (cultivated) } \\ 185\end{array}$


Appendix IIa. Correlation matrix for physical-chemical data collected in the survey of 16 SRP Carolina bays in the summer of 1979. [Values of correlation coefficient $r, n=32$, significant $r(p=0.01)=0.514$ ]

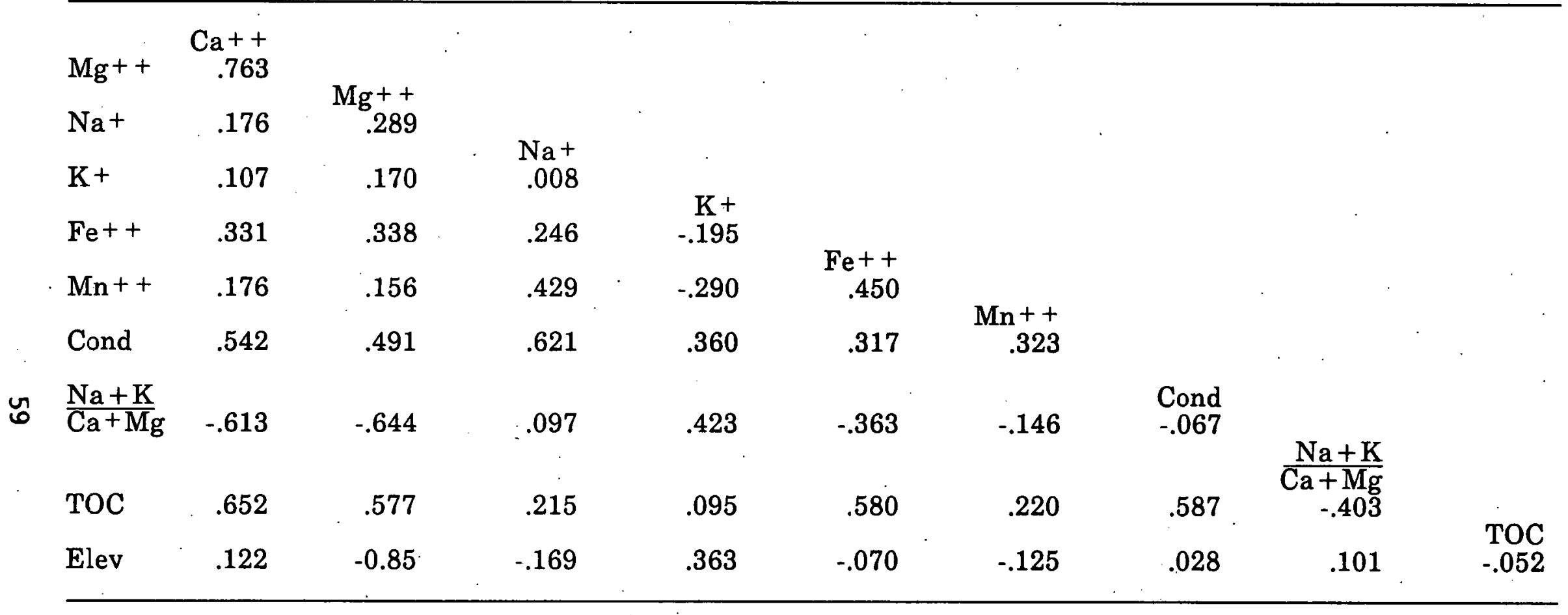

Variables: (6 Cations), Cond = conductivity, $\frac{\mathrm{Na}+\mathrm{K}}{\mathrm{Ca}+\mathrm{Mg}}=$ ratio of major monovalent and divalent cations, TOC $=$ total dissolved organic carbon, Elev = elevation of bay depression. 
Appendix Ib. Correlation matrix for physical-chemical data collected in the survey of 18 SRP Carolina bays in the winter of 1979-80. [Values of correlation coefficient $r, n=54$, significant $r(p=0.01)=0.348$ ]

\begin{tabular}{|c|c|c|c|c|c|c|c|c|c|}
\hline $\begin{array}{l}\mathrm{Ca}^{++} \\
\mathrm{Mg}+ \\
\mathrm{Mn}^{++}+ \\
\mathrm{Fe}^{++} \\
\mathrm{K}^{+} \\
\mathrm{H}+ \\
\Sigma \mathrm{Cat}\end{array}$ & $\begin{array}{r}\mathrm{Na}+ \\
.338 \\
.418 \\
.088 \\
.400 \\
.279 \\
-.139 \\
.628\end{array}$ & $\begin{array}{r}\mathrm{Ca}++ \\
.796 \\
.455 \\
.256 \\
.194 \\
-.371 \\
.738\end{array}$ & $\begin{array}{r}\mathrm{Mg}^{++} \\
.647 \\
.337 \\
.385 \\
-.206 \\
.884\end{array}$ & $\begin{array}{r}\mathrm{Mn}++ \\
.344 \\
.147 \\
-.175 \\
.550\end{array}$ & $\begin{array}{r}\mathrm{Fe}++ \\
.085 \\
-.148 \\
.457\end{array}$ & $\begin{array}{r}\mathrm{K}+ \\
-.415 \\
.281\end{array}$ & $\begin{array}{l}\mathrm{H}+ \\
.080\end{array}$ & $\Sigma$ Cat & \\
\hline$\frac{\mathrm{Na}+\mathrm{K}}{\mathrm{Ca}+\mathrm{Mg}}$ & .429 & -.561 & -.371 & -.261 & $\therefore .052$ & .264 & .041 & -.210 & \\
\hline $\begin{array}{l}\text { Cond } \\
\text { TC } \\
\text { TIC } \\
\text { TOC } \\
\text { RDX } \\
\text { Temp } \\
\text { Oxy } \\
\text { Elev }\end{array}$ & $\begin{array}{r}.437 \\
.172 \\
.047 \\
.071 \\
-.108 \\
-.311 \\
-.063 \\
.237\end{array}$ & $\begin{array}{r}.265 \\
.654 \\
.162 \\
.579 \\
. .269 \\
-.024 \\
-.141 \\
.300\end{array}$ & $\begin{array}{r}.519 \\
.819 \\
.148 \\
.801 \\
-.113 \\
-.173 \\
-.226 \\
.325\end{array}$ & $\begin{array}{r}.292 \\
.701 \\
.229 \\
.583 \\
-.167 \\
.049 \\
-.172 \\
.209\end{array}$ & $\begin{array}{r}.107 \\
.307 \\
.290 \\
.265 \\
. .194 \\
.212 \\
. .219 \\
.054\end{array}$ & $\begin{array}{r}.321 \\
.294 \\
-.027 \\
.264 \\
-.329 \\
-.258 \\
-.063 \\
.130\end{array}$ & $\begin{array}{r}-.114 \\
-.002 \\
-.074 \\
.097 \\
.415 \\
.241 \\
-.233 \\
-.090\end{array}$ & $\begin{array}{r}.467 \\
.769 \\
.159 \\
.765 \\
-.088 \\
-.067 \\
-.314 \\
.319\end{array}$ & $\begin{array}{r}\mathrm{Ca}+\mathrm{Mg} \\
.104 \\
-.387 \\
-.152 \\
-.427 \\
-.085 \\
-.194 \\
.095 \\
.115\end{array}$ \\
\hline $\begin{array}{l}\text { TC } \\
\text { TIC } \\
\text { TOC } \\
\text { RDX } \\
\text { Temp } \\
\text { Oxy } \\
\text { Elev }\end{array}$ & $\begin{array}{r}\text { Cond } \\
.366 \\
-.347 \\
.171 \\
-.155 \\
.700 \\
.088 \\
.211\end{array}$ & $\begin{array}{r}\mathrm{TC} \\
.171 \\
.998 \\
-.227 \\
.012 \\
-.363 \\
.306\end{array}$ & $\begin{array}{l}\text { TIC } \\
.104 \\
.179 \\
.461 \\
-.338 \\
. .302\end{array}$ & $\begin{array}{r}\text { TOC } \\
-.135 \\
.089 \\
-.444 \\
.221\end{array}$ & $\begin{array}{r}\text { RDX } \\
.075 \\
-.101 \\
-.249\end{array}$ & $\begin{array}{r}\text { Temp } \\
-.106 \\
-.016\end{array}$ & $\begin{array}{l}\text { Oxy } \\
.219\end{array}$ & & \\
\hline
\end{tabular}

Variables: $(7$ Cations), $\Sigma C$ at $=$ total cations $(\mathrm{meq} / \mathrm{l}), \mathrm{Na}+\mathrm{K}=$ ratio of major monovalent and divalent cations, $\mathrm{Ca}+\mathrm{Mg}$

Cond $=$ conductivity, $\mathrm{TC}=$ total dissolved carbon, $\mathrm{TIC}=$ total dissolved inorganic carbon, $\mathrm{TOC}=$ total dissolved organic carbon, $\mathrm{RDX}=$ redox potential, $\mathrm{Temp}=$ water temperature, $\mathrm{Oxy}=$ dissolved oxygen (previous 3 measured near surface with portable hydrolab),

Elev = elevation of bay depression. 
Appendix III. Tree, shrub, herb, and Sphagnum species collected or observed in Carolina bays of Aiken and Barnwell Counties, SC on or adjacent to the SRP (Hodge 1985).

\section{TREES}

Acer rubrum L.

Diospyros virginiana $\mathrm{L}$.

Liquidambar styraciflua L.

Nyssa sylvatica Marsh var. biflora (Walt.) Sarg.

Pinus palustris Mill.

Pinus serotina Michx.

Pinus taeda L.

Quercus nigra L.

Taxodium ascendens Brongon.

\section{SHRUBS}

Callicarpa americana $\mathrm{L}$.

Cephalanthus occidentalis $\mathrm{L}$.

Cyrilla racemiflora $\mathrm{L}$.

Gaylussacia frondosa (L.) T. and G. frondosa var. tomentosa Gray

Hypericum stans (Michx.) Adams and Robson

Ilex cassine L. var. myrtlifolia (Walt.) Sarg.

Ilex glabra (L.) Gray

Ilex opaca Ait.

Leucothoe racemosa (L.) Gray

Lyonia ligustrina (L.) DC

Lyonia lucida (Lam.) Koch

Lyonia mariana (L.) D. Don

Magnolia virginiana L.

Myrica cerifera L.

Persea borbonia (L.) Spreng.

Rhododendron viscosum (L.) Torr. var. serrulatum (Sm.) Ahles 
Appendix III--Continued

SHRUBS--Continued :

Rhus copallina $\mathrm{L}$.

Salix nigra Marsh.

Sassafras albidum (Nutt.) Nees.

Sorbus arbutifolia (L.) Heynhold

Stillingia aquatica Champ.

Vaccinium amoenum Ait.

Vaccinium arboreum Marsh.

Vaccinium corymbosum $\mathrm{L}$.

Vaccinium stamineum $\mathrm{L}$.

\section{HERBS}

Agrostis hyemalis (Walt.) BSP.

Ampelopsis arborea (L.) Koehne

Andropogon ternarius Michx.

Andropogon virginicus L.

Aristida affinis (Schult.) Kunth

Bacopa caroliniana (Walt.) Robins

Bartonia verna (Michx.) Muhl.

Boltonia asteroides (L.) L'Her.

Brasenia schreberi Gmel.

Carex complanata Torr. and Hook

Carex glaucescens Ell.

Carex walteriana Bailey

Centella asiatica (L:) Urban

Chondrophora nudata (Michx.) Britt.

Coreopsis rosea Nuh.

Croton elliottii Chapm.

Diodia virginiana L.

Drosera capillaris Poir.

Drosera intermedia Hayne in Schrad.

Eleocharis acicularis (L.) R. and S.

Eleocharis equisetoides (Ell.) Torr.

Eleocharis obtusa (Willd.) Schultes in R. and S.

Eleocharis quadrangulata (Michx.) R. and S. 
Appendix III--Continued

\section{HERBS-Continued}

Eleocharis tricostata Torr.

Echinodorus parvulus Engelm.

Erianthus alopecuroides (L.) Ell.

Erianthus brevibarbis Michx.

Erianthus giganteus (Walt.) Muhl.

Erianthus strictus Baldw.

Erigeron vernus (L.) T. and G.

Eriocaulon compressum Lam.

Eriocaulon decangulare L.

Eupatorium album L.

Eupatorium capillifolium (Lam.) Small

Eupatorium leucolepis (DC.) T. and G.

Eupatorium leptophyllum DC.

Fimbristylis autumnalis (L.) R. and S.

Fimbristylis dichotoma (L.) Vahl

Fimbristylis spadicea Roth

Fuirena pumila (Torr.) Spreng.

Habenaria cristata (Michx.) R. Br. in Ait.

Helenium brevifolium (Nutt.) Wood

Helenium flexuosum Raf.

Helenium pinnatifidum (Nutt.) Rydb.

Helianthus angustifolius L.

Hibiscus moschuetos $\mathrm{L}$.

Hydrochloa caroliniensis Beauv.

Hydrocotyle americana L.

Hypericum cistifolium Lam.

Hypericum virginicum $\mathrm{L}$.

Hypericum walteri Gmelin

Iris virginica $\mathrm{L}$.

Juncus acuminatus Michx.

Juncus biflorus Ell.

Juncus canadensis J. Gay ex Laharpe

Juncus coriaceus Mack.

Juncus debilis Gray 
Appendix III--Continued

HERBS--Continued

Juncus diffusissimus Buckl.

Juncus effusus L.

Juncus marginatus Rostk.

Lachnanthes caroliniana (Lam.) Dandy

Lachnocaulon anceps (Walt.) Morong

Leersia hexandra Sw.

Lobelia boykinii T. and G.

Lobelia nuttallii R. and S.

Ludwigia arcuata Walt.

Ludwigia alternifolia L.

Ludwigia decurrens Walt.

Ludwigia palustris (L.) Ell.

Ludwigia spathulata T. and G.

Ludwigia sphaerocarpa Ell.

Ludwigia suffruticosa Walt.

Lycopodium alopecuroides $\mathrm{L}$.

Lycopus virginicus $\mathrm{L}$.

Manisuris rugosa (Nutt.) Kunte

Myriophyllum heterophyllum Michx.

Myriophyllum laxum Shuttlew

Myriophyllum pinnatum (Walt.) BSP.

Nelumbo lutea (Willd.) Pers.

Nymphaea odorata Ait.

Nymphoides cordata (Ell.) Fern.

Osmunda cinnamomea $\mathrm{L}$.

Osmunda regalis L. var. spectabilis (Willd.) Gray

Oxypolis canbyi (Coult. and Rose) Fern.

Panicum anceps Michx.

Panicum commutatum Schultes

Panicum dichotomiflorum Michx.

Panicum dichotomum $\mathrm{L}$. 
Appendix III--Continued

\section{HERBS--Continued}

Panicumensifolium Baldw. ex Ell.

Panicum hemitomon Schultes

Panicum hians Ell.

Panicum lanuginosum Ell.

Panicum laxiflorum Lam.

Panicum leucothrix Nash

Panicum longifolium Torrey

Panicum ravenelii Scribner ex Merrill

Panicum verrucosum Muhl.

Panicum virgatum $\mathrm{L}$.

Panicum wrightianum Scribner

Paspalum notatum Flugge

Pluchea foetida (L.) DC.

Polygala cymosa Wah.

Polygala lutea L.

Polygonum hirsutum Walt.

Pontederia cordata L.

Potamogeton diversifolius Raf.

Proserpinaca palustris L.

Proserpinaca pectinata Lam.

Psilocarya nitens (Vahl.) Wood.

Ptilimnium nodosum (Rose) Mathias

Pycnanthemum flexuosum (Walt.) BSP.

Rhexia aristosa Britt.

Rhexia lutea Walt.

Rhexia mariana L. var. exalbida Michx.

Rhexia mariana L. var. mariana Michx.

Rhexia mariana L. var. purpurea Michx.

Rhynchospora corniculata (Lam.) Gray

Rhynchospora globularis (Chapm.) Small

Rhynchospora inexpansa (Michx.) Vahl

Rhynchospora inundata (Oakes) Fern. 
Appendix III--Continued

HERBS--Continued

Rhynchospora macrostachya Torrey

Rhynchospora rariflora (Michx.) Ell.

Rhynchospora tracyi Brih.

Rubus spp.

Sábatia sp.

Sagittaria graminea Michx.

Sagittaria isoetiformis J. G. Sm.

Sagittaria latifolia Willd.

Sarracenia minor Walt.

Scirpus cyperinus (L.) Kunth

Scirpus etuberculatus (Steud.) Kuntze

Scleria ciliata Michx.

Scleria georgiana Core

Scleria reticularis Michx.

Sclerolepis uniflora (Wah.) BSP.

Similax bona-nox L.

Smilax glauca Walt.

Smilax laurifolia L.

Smilax smallii Morong.

Smilax walteri Pursh

Solidago leavenworthii T. and G.

Spiranthes laciniata (Small) Ames.

Spiranthes vernalis Engelm. and Gray

Sporobolus sp.

Tofieldia racemosa (Walt.) BSP.

Typha latifolia $\mathrm{L}$.

Utricularia fibrosa Walt.

Utricularia inflata Walt.

Utricularia olivacea Wright ex Griseb.

Utricularia purpurea Walt.

Viola lanceolata L.

Viola villosa Walter 
Appendix III--Continued

HERBS--Continued

Woodwardia virginica (L.) Sm.

$X y r i s$ caroliniana Walt.

Xyris platylepis Chapm.

\section{SPHAGNUM}

Sphagnum cyclophyllum Sull. and Lesq. ex. Sull.

Sphagnum cuspidatum Ehrh. ex Hoffm.

Sphagnum imbricatum Hornsch. ex Russ.

Sphagnum lescurii Sull.

Sphagnum macrophyllum Bernh. ex Brid.

Sphagnum perichaetiale Hampe

Sphagnum recurvum $\mathrm{P}$.-Beauv.

Sphagnum strictum Sull.

Sphagnum subsecundum Nees ex Sturm var. rufescens Hub.

Sphagnum torreyanum Sull.

Sphagnum trinitens. Sull. 
Appendix IV. Reptile and amphibian species collected or observed in Carolina bays on the Savannah River Plant, South Carolina, based on records in Gibbons and Semlitsch (1990).

\section{CLASS AMPHIBIA}

Order Caudata Salamanders

Family: Amphiumidae

Amphiuma means

Family: Sirenidae

Siren intermedia

Siren lacertina

Family: Ambystomatidae

Ambystoma opacum

Ambystoma talpoideum

Ambystoma tigrinum

Family: Salamandridae

Notophthalmus viridescens

Family: Plethodontidae

Eurycea cirrigera

Eurycea longicauda

Eurycea quadridigitata

Plethodinn gliutinosus

Pseudotriton montanus

Pseudotriton ruber

Order Anura Frogs and toads

Family: Pelobatidae

Scaphiopus holbrooki

Family: Bufonidae

Bufo quercicus

Bufo terrestris

Family: Hylidae

Acris gryllus

Hyla avivoca

Hyla chrysoscelis

Hyla cinerea

Hyla femoralis

Hyla gratiosa two-toed amphiuma

lesser siren

greater siren

marbled salamander

mole salamander.

tiger salamander

eastern newt

two-lined salamander

long-tailed salamander

dwarf salamander

slimy salamander

mud salamander

red salamander

eastern spadefoot toad

oak toad

southern toad

southern cricket frog

bird-voiced treefrog

Cope's gray treefrog

green treefrog

pine woods treefrog

barking treefrog 
Hyla squirella

Pseudacris crucifer

Pseudacris nigrita

Pseudacris ornata

Family: Microhylidae

Gastrophryne carolinensis

Family: Ranidae

Rana areolata

Rana catesbeiana

Rana clamitans

Rana grylio

Rana palustris

Rana utricularia

Rana virgatipes

\section{CLASS REPTILIA}

Order Crocodilia Crocodilians

Family: Alligatoridae

Alligator mississippiensis

Order Chelonia Turtles

Family: Chelydridae

Chelydra serpentina

Family: Kinosternidae

Kinosternon bauri

Sternotherus odoratus

Kinosternon subrubrum

Family: Emydidae

Pseudemys floridana

Chrysemys picta

Trachemys scripta

Clemmys guttata

Deirochelys reticularia

Order Squamata

Suborder Serpentes Snakes

Family: Colubridae

* Cemophora coccinea

* Coluber constrictor

* Diadophis punctatus

* Elaphe guttata

Elaphe obsoleta squirrel treefrog

spring peeper

southern chorus frog

ornate chorus frog

narrow-mouthed toad

crawfish frog

bullfrog

green frog

pig frog

pickerel frog

southern leopard frog

carpenter frog common snapping turtle

striped mud turtle

stink pot

eastern mud turtle

Florida cooter

painted turtle

slider turtle

spotted turtle

chicken turtle scarlet snake racer (black racer)

ringneck snake

corn snake

rat snake 
Farancia abacura

Farancia erytrogramma

* Heterodon platirhinos

* Lampropeltis getulus

Nerodia cyclopion

Nerodia erythrogaster

Nerodia fasciata

Regina rigida

* Rhadinaea flavilata

Seminatrix pygaea

* Storeria dekayi

* Storeria occipitomaculata

* Tantilla coronata

Thamnophis sauritus

Thamnophis sirtalis

* Virginia valeriae

Family: Viperidae (=Crotalidae)

Agkistrodon piscivorus mud snake

rainbow snake

eastern hognose snake

common kingsnake

green water snake

red-bellied water snake

banded water snake

glossy crayfish snake

yellow-lipped snake

black swamp snake

brown snake

red-bellied snake

southeastern crowned snake.

eastern ribbon snake

common garter snake

smooth earth snake

cottonmouth

* Species is normally terrestrial in periphery of bays and other aquatic habitats 